\title{
POTENCIALIDADE DE GENÓTIPOS DE SOJA (Giycine max (L.) MERRILL) PARA CULTIVO DE INVERNO AVALIADA POR CRUZAMENTOS DIALÉLICOS
}

\author{
LUCIANO LOURENÇO NASS
}

Engenheiro Agrônomo

Orientador: Prof.Dr. Natal Antonio Vello

Dissertação apresentada à Escola Superior de Agricultura "Luiz de Queiroz", da Universidade de São Paulo, para obtenção do título de Mestre em Agronomia. Ārea de Concentração: Genética e Melhoramento de Plantas

\author{
PIRACICABA \\ ESTADO DE SÃO PAULO - BRASIL \\ JANEIRO DE 1989
}




\footnotetext{
Nass, Luciano Lourenço

N265p Potencialidade de genótipos de soja (Glycine $\max$ (L.) Merrill) para cultivo de inverno avaliada por cruzamentos dialélicos. Piracicaba, 1989.

112p. ilus.

Diss. (Mestre) - ESALQ

Bibliografia

1. Soja - Cruzamento dialélico. 2. Soja-Cul tivo de inverno. 3. Soja - Genótipo. 4. Soja Melhoramento. I. Escola Superior de Agricultura "Luiz de Queiroz", Piracicaba.
}

CDD 633.34 


\title{
POTENCIALIDADE DE GENOTIPOS DE SOJA (Glycine max (L.) MERRILL） PARA CULTIVO DE INVERNO AVALIADA POR CRUZAMENTOS DIALELICOS
}

\author{
Luciano Lourenço Nass
}

Aprovado em: 27.03 .1989

Comissão julgadora:

Prof. Dr. Natal Antonio Vello

ESALQ/USP

Prof. Dr. Roland Vencovsky

ESALQ/USP

Prof. Dr. Décio Barbin

ESALQ/USP

$$
1-1-1 \mid \cdot r
$$

Prof. Dr. Natal Antonio Vello Orientador 
A minha avó Laura

Aos meus pais Lucy e ottomar

e a minha irmã Lísian

DEDICO.

Ao Rivail, Sidival e a Nilce

OFEREÇO. 
Ao Prof.Dr. Natal Antonio Vello pela valiosa orientação, ensinamentos e colaboração na realização deste trabalho.

A Fundação de Amparo à Pesquisa do Estado de São Paulo (FAPESP) e ao Departamento de Genética da Escola Superior de Agricultura "Luiz de Queiroz" (ESALQ), que tornaram possível a realização deste curso. À EMBRAPA pelo apoio financeiro para condução dos experimentos.

Aos Professores do Departamento de Genética da ESALQ pelos ensinamentos recebidos e em particular aos Professores Drs. José Branco de Miranda Filho e Isaias Olívio Geraldi que juntamente com o Prof. Natal Antonio Vello, compuseram a banca do meu exame geral de qualificação.

A Ana Maria R. Cassiolato e Tania Marta C. dos Santos pela convivência agradável, pura e carinhosa; aos amigos Telmo Canton e Nilson A. Villa Nova pela força, amizade e companheirismo.

Á bibliotecāria Nilce T. Puga pela revisão de literatura; às funcionārias Terezinha de Jesus L. Barrete, Olívia R. Pachane e aos demais funcionārios do Departamento de Genētica da ESALQ, pela atenção e presteza.

Aos colegas Telmo Canton, Arnoldo Meister Pimentel e Cláudio Luiz Dias pelo apoio e indispensável colaboração nos trabalhos experimentais. 
Aos funcionários do Laboratório de Soja, Antônio Roberto Cogo, Claudinei Antônio Didoné e Osmair José da Silva e ainda aos funcionários Âlvaro Gomes e Orides Alves Cardoso pelo apoio e dedicação na rea1ização dos trabalhos de campo e de laboratório.

Ao Centro de Informätica na Agricultura (CIAGRI) pelas instalações cedidas e aos seus funcionários pelos trabalhos prestados.

Aos meus queridos sobrinhos Luciana, Diego e Gabriel, e ainda ao Mário Sérgio e Marcus Vinicius.

A Sra. Elisa S. Peron pelo eficiente trabalho de datilografia. 
INDICE

Pägina

RESUMO $\ldots \ldots \ldots \ldots \ldots \ldots \ldots \ldots \ldots \ldots \ldots \ldots \ldots \ldots \ldots \ldots \ldots \ldots \ldots \ldots \ldots \ldots \ldots \ldots \ldots$

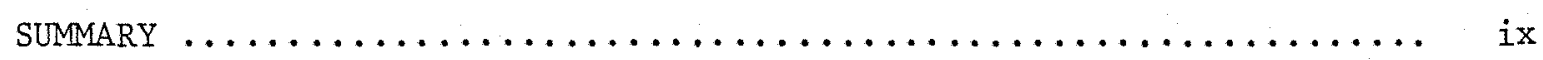

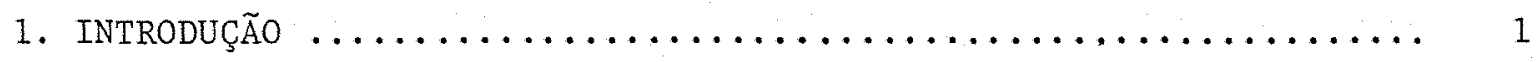

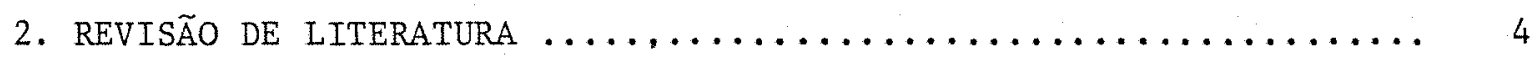

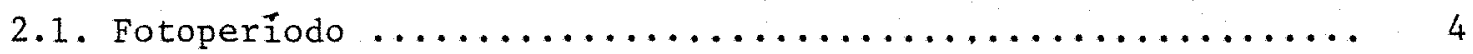

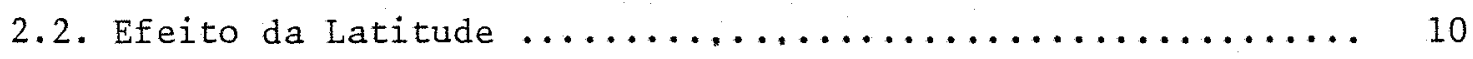

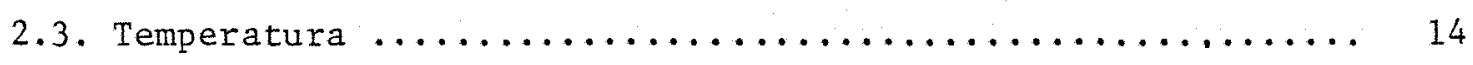

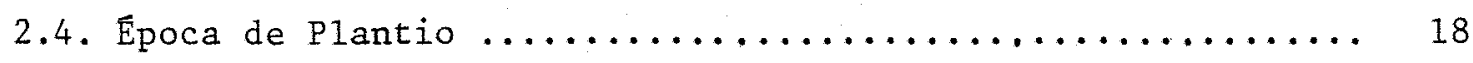

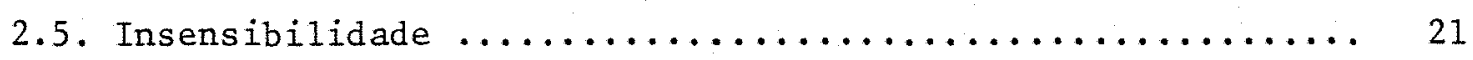

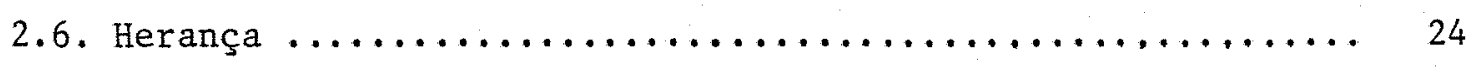

2.7. Heterose e Heterobeltiose $\ldots \ldots \ldots \ldots \ldots \ldots \ldots \ldots \ldots \ldots \ldots . \ldots \ldots$

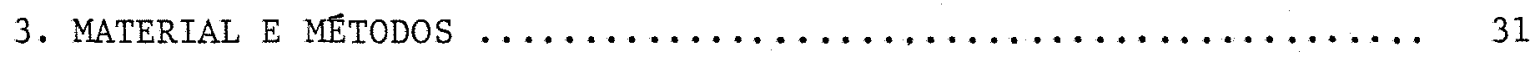

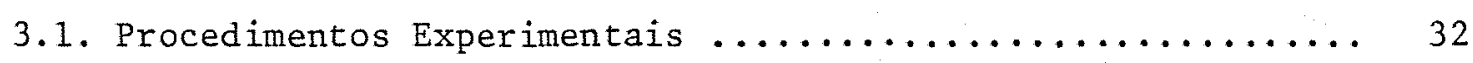

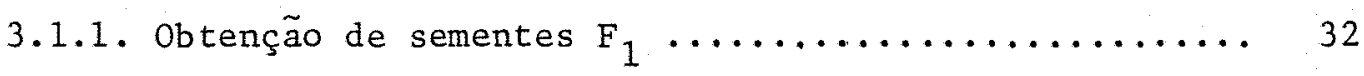

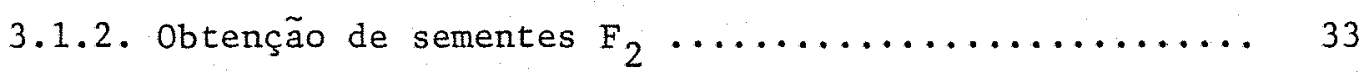

3.1.3. Delineamentos e descriçōes dos experimentos ...... 34

3.1.4. Caracteres avaliados ................... 36

3.2. Anälises Estatistico-Genēticas ............... 38

3.2.1. Anālise de variância $\ldots \ldots \ldots \ldots \ldots \ldots \ldots \ldots \ldots \ldots \ldots \ldots$

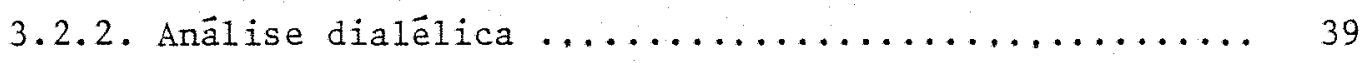

3.3. Heterose e Heterobeltiose $\ldots \ldots \ldots \ldots \ldots \ldots \ldots \ldots \ldots \ldots .43$

3.4. Comparação dos tipos de parcelas experimentais ......... 44 


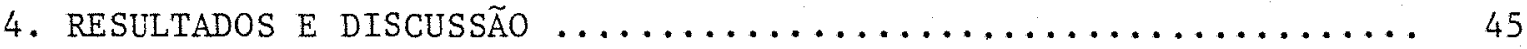

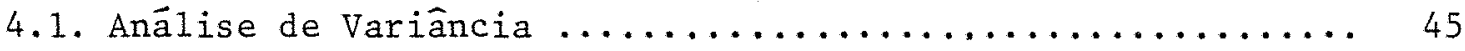

4.2. Avaliação dos parentais, progênies $F_{2}$, heterose e

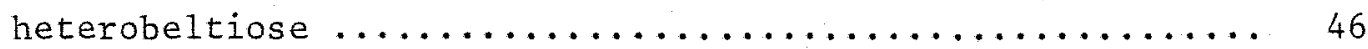

4.2.1. Caracteres relacionados ao florescimento ........ 46

4.2.2. Caracteres relacionados à maturidade .......... 51

4.2.3. Acamamento, valor agronōmico e produtividade ..... 57

4.3. Anālise dialélica de Griffing .................. 63

4.3.1. Efeitos da CGC $\ldots \ldots \ldots \ldots \ldots \ldots \ldots \ldots \ldots \ldots \ldots \ldots \ldots$

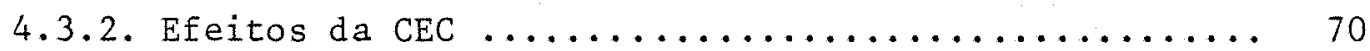

4.4. Comparação dos tipos de parcelas experimentais ........ 77

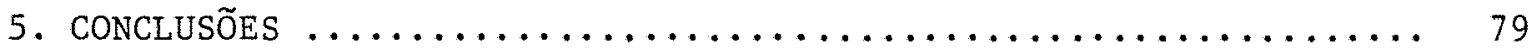

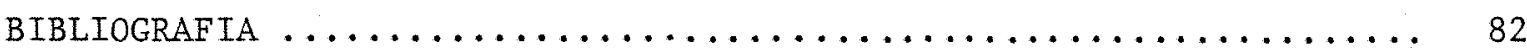

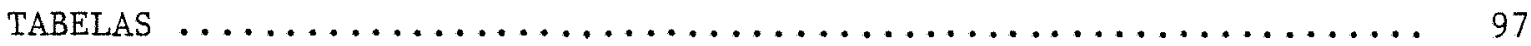

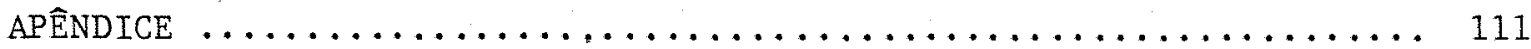




\author{
POTENCIALIDADE DE GENOTIPOS DE SOJA (Glycine max (L.) \\ MERRILL) PARA CULTIVO DE INVERNO AVALIADA POR \\ CRUZAMENTOS DIALELICOS
}

Autor: Luciano Lourenço Nass

Orientador: Prof. Dr. Natal Antonio Vello

RE S UMO

No Estado de São Paulo, como alternativa tecnológica, a so ja vem sendo cultivada no inverno em sucessão ao cultivo de verão, repre sentado preferencialmente por uma gramínea de ciclo precoce. o presente trabalho teve como objetivos principais a avaliação do potencial genético e da capacidade de combinação de genótipos semi-tardios de soja, visando ao cultivo de inverno. Foram utilizados dez parentais (Cristalina, EMGOPA-301, IAC-4, IAC-5, IAC-6, IAC-8, IAC-9, IAC-11, Santa Rosa e SS-1, por apresentarem período juvenil acentuado, níveis altos de produtividade e certa divergência genëtica) e as progênies $F_{2}$ obtidas por cruzamentos dia lë1icos.

No período de 21 de janeiro (plantio) a 21 de julho de 1988 (colheita do genótipo mais tardio), foram conduzidos três experimentos em Piracicaba-SP, em ambiente caracterizado por $22042^{\prime}$ de latitude Sul, 47038' de longitude Oeste e $537 \mathrm{~m}$ de altitude. O experimento 1 incluiu todos os cruzamentos e conservou o esquema dialélico; foi usado o delineamento em lätice $8 \times 8$ com tratamentos adicionais e cinco repetições; a parcela foi representada por nove plantas distribuidas individualmente em covas; 
- espaçamento entre covas foi de $0,60 \mathrm{~m}$. Os outros dois experimentos possuíram menor nümero de tratamentos, sendo as parcelas representadas por fileiras de 1 e 3m. Nestes dois experimentos, foi utilizado o delineamen to em blocos casualizados com quatro repetições. Os caracteres avaliados foram os seguintes: nümero de dias para florescimento e maturidade, número de internódios no florescimento e na maturidade, altura da planta no florescimento e na maturidade, acamamento, valor agronômico (notas visuais) e produtividade de planta individual.

o lātice não apresentou eficiência em relação a blocos casualizados, assim as anālises foram refeitas em blocos. Os parentais e as progênies $\mathrm{F}_{2}$ apresentaram diferenças significativas entre si para todos os caracteres, evidenciando um elevado potencial para formação de uma população de base genêtica ampla, visando a obtenção de combinações superiores para o cultivo de inverno. A heterose e a heterobeltiose apresentaram variação ampla; geralmente as suas maiores estimativas estiveram relacionadas às maiores médias, porém, nem sempre corresponderam às maiores variâncias. A anālise de Griffing revelou maior importância da capacidade geral de combinação (CGC) em relação a capacidade especî́fica de combinação (CEC), sendo a razão $C G C /(C G C+C E C)$ superior a 0,9 em todos os caracteres. As esti mativas do efeito da capacidade geral de combinação $\left(g_{\dot{1}}\right)$, do efeito da capacicade específica de combinação de um parental com ele mesmo $\left(s_{i j}\right)$ e do efeito da capacidade específica de combinação para o cruzamento entre dois parentais ( $s_{i j}$ para $i \neq j$ ), apresentaram variação em todos os caracteres. No caräter produtividade (PPI), os parentais Cristalina, IAC-11 e SS-1, obtiveram as melhores estimativas para $g_{i}$; alem disso, participaram dos cruzamentos mais expressivos para esse carāter. A avaliação das progê- 
nies $\mathrm{F}_{2}$ em covas individuais, mostrou-se bastante satisfatória em discriminar os cruzamentos de maior potencial. 


\author{
POTENTIAL OF SOYBEAN (Glycine max (L.) MERRILL) \\ GENOTYPES AS WINTER CROP EVALUATED THROUgh DIALLEL CROSSES
}

Author: Luciano Lourenço Nass Adviser: Prof. Dr. Natal Antonio Vello

SUMMARY

Soybean has been grown as a winther crop as a technological alternative, succeeding the summer crops usually represented by maize, sorghum, or other early graminaceous crop, in the State of São Paulo, Brazil. This research aimed to evaluate the potential of semi-late soybean genotypes for winter cropping. Based on juvenile period, high seed yielding, and genetic divergence, ten genotypes were chosen as parents: Cristalina, EMGOPA-301, IAC-4, IAC-5, IAC-6, IAC-8, IAC-9, IAC-11, Santa Rosa and SS-1. These ten parents and their $F_{2}$ diallel progenies were tested in field conditions.

Three experiments were carried out in Piracicaba, State of São Paulo, Brazil, at 22042' South latitude, 47038' West longitude, and $537 \mathrm{~m}$ altitude, from January 21 (planting) to June 21, 1988 (harvest of the latest genotype). The first experiment included all $F_{2}$ progenies of the diallel crossing system, in a $8 \times 8$ lattice design with five replications; each plot corresponded to nine hills spaced $0.60 \mathrm{~m}$ apart, with one plant each; an additional $0.60 \mathrm{~m}$ space separated two neighbour plots. The other two experiments included only part of the $F_{2}$ progenies in a 
randomized complete block design with four replications. In these two experiments, a plot was represented by rows of $1 \mathrm{~m}$ and $3 \mathrm{~m}$, respectively, spaced $0.60 \mathrm{~m}$ apart. The ten parents participated in all three experiments. Nine characters were evaluated: time to flowering and to maturity, numbers of internodes at flowering and at maturity, plant height at flowering and at maturity, lodging, agronomic value (visual scores), and seed yield on individual plant basis.

The lattice design was not efficient, and data were then analysed as a randomized complete block design. Significance was detected among parents and $F_{2}$ progenies for all the characters. This fact showed the high potential of these materials in synthesizing a population with large genetic basis for recurrent selection of genotypes appropriate to winter cropping. Large ranges of values were estimated for heterosis and heterobeltiosis; the largest estimates were related to the largest means, but not always they corresponded to the largest variances. Grif fing's analysis revealed that general combining ability (gca) was much more important than specific combining ability (sca); the relation gca/(gca+sca) was superior to 0.9 for all characters. There were variations among general and specific effects for all characters. 'Cristalina', 'IAC-1I', and 'SS-1' presented the largest values of general combining effect and participated in the crosses with superior seed yield. Relatively high correlations indicated efficiency of individual plant hill plot in discriminating the crosses with superior potential for winter cropping, when compared to evaluations using rows as plots. 
1. INTRODUÇÃO

A soja (Glycine $\max$ (L.) Merrill) è uma espécie autōgama, de grande importância mundial, atingindo aproximadamente 100 milhões de toneladas em 1985. No Brasil, em 1986, a produção foi de $13.335 .000 t$ em uma ärea de $9.186 .000 \mathrm{ha}$, com produtividade de $1.452 \mathrm{~kg} / \mathrm{ha}$ (FAO PRODUCTION YEARBOOK, 1986).

De acordo com VELLO (1985) o interesse mundial pela soja deve-se à excelente combinação que a espécie apresenta em termos de produtividade (geralmente acima de $2 t / h a$ ) e porcentagens de óleo e de proteína, que em média, correspondem a 20 e $40 \%$ do peso das sementes, respectivamente.

Na década de 70, a soja apresentou aumentos significativos de produção, porém, esse cultivo limitava-se às regiões sul e Sudeste. A partir de 1980 , a região Central contribuiu para a expansão da cultura no território nacional, com produtividade atual semelhante às obtidas nas regiões tradicionais. Recentemente, com a disponibilidade de cultivares adaptados às baixas latitudes, tornou-se possivel o cultivo de soja em todas as regiões do Brasil (BONATO \& DALL'AGNOLL, 1985). 
A crescente expansão da soja requer cultivares com caracteres específicos para atender às exigências dos diversos ambientes. Um des tes caracteres é o período juvenil longo. Entende-se por período juvenil o número de dias entre a emergência da plântula (início da recepção de 1uz) e o começo do processo de indução do florescimento. A ampliação do periodo juvenil de 9 dias (genótipos sensíveis ao fotoperíodo) para mais de 20 dias (genótipos tolerantes ao fotoperíodo) permite maior crescimento vegetativo da planta e, conseqlentemente, aumenta o seu potencial de pro dutividade de sementes. Diferenças genéticas entre cultivares de soja quan to à duração do período juvenil, sob condições de dias curtos, foram detec tadas por KIIHL (1976) e TISSELI JUNIOR (1981), possibilitando alteração desse caräter em programas de melhoramento conduzidos sob tais condições.

As influências de fatores ambientais sobre os genótipos de soja são muito pronunciadas. A temperatura tem efeito mais pronunciado so bre os genótipos precoces, enquanto que o fotoperiodo é mais limitante nos genótipos tardios. Os genótipos classificados como tardios na época normal de cultivo (plantio em outubro ou novembro) são os que oferecem melhores possibilidades para cultivo de inverno (plantio em fevereiro), princi palmente devido ao menor efeito da temperatura sobre o desenvolvimento e a produtividade destes genótipos. O deslocamento da época de plantio de outubro para fevereiro traz como conseqtência imediata o encurtamento do ciclo, tornando os genótipos menos tardios. Este efeito sobre o ciclo pode ser muito drástico, ao ponto de limitar a utilização, no cultivo de inverno, da maioria dos genótipos de soja atualmente disponíveis.

Esse trabalho integra o Programa de Soja do Setor de Genética Aplicada às Espécies Autógamas do Instituto de Genética da Escola 
Superior de Agricultura "Luiz de Queiroz", da Universidade de São Pau10, que entre seus objetivos visa desenvolver novos genótipos de soja me nos sensiveis ao fotoperíodo, para utilização na safra de inverno. No Estado de São Paulo, o cultivo de inverno apresenta-se como uma tecnologia al ternativa em relação ao cultivo normal. Esta possibilidade è particularmente promissora em sistemas agronômicos que envolvem sucessão de espécies diferentes e nos quais o cultivo da época normal (verão) $\vec{e}$ representa do por uma gramínea (milho, sorgo, etc) de ciclo precoce. Para alcançarem níveis altos de produtividade em cultivos de inverno, os cultivares de vem apresentar período juvenil longo, tolerância às baixas temperaturas e pouca exigência em ägua. Assim sendo, este estudo teve os seguintes objetivos:

a) avaliação do potencial genētico e da capacidade de com binação de genōtipos parentais;

b) identificação dos cruzamentos de maior potencial com base na mëdia, na variância da geração $F_{2}$ e na capacidade de combinação dos parentais;

c) estimação de parâmetros genēticos para caracteres agronō micos;

d) comparação do comportamento dos parentais e das progênies $F_{2}$ em diferentes tipos de parcelas experimentais. 


\section{REVISÃO DE LITERATURA}

\subsection{Fotoperiodo}

A influência do período luminoso para o crescimento e desenvolvimento das plantas tem sido objeto de muitos estudos. Mooers, citado por HOWELL (1963), observou diferenças no fotoperíodo da soja semeada em épocas diferentes. GARNER \& ALLARD (1920) após estudarem o efeito do comprimento do dia no desenvolvimento de algumas espécies, sugeriram os termos fotoperiodo para designar o comprimento do dia favorävel para cada organismo e fotoperiodismo para a resposta do organismo para o comprimento relativo entre dia e noite.

Quando a soja foi classificada como uma espécie de dias curtos, acreditava-se que um período luminoso curto seria o responsável pela indução do florescimento. Sabe-se hoje que é o número de horas de escuridão que determina a indução do florescimento e não o número de horas do periodo luminoso diärio (BORTHWICK \& PARKER, 1938a,b). Estes autores observaram que o estimulo causado por dois fotoperiodos curtos sucessivos foram suficientes para dar início à diferenciação dos 
primórdios florais e relataram que as folhas são os pontos de percepção do estimulo. Em estudos posteriores, utilizando o cultivar "Biloxi", BORTHWICK \& PARKER (1940) analisaram a relação da idade e posição das folhas quanto à sua eficiência na iniciação floral. Concluíram que a folha mais eficiente é a que recentemente atingiu o completo desenvolvimento; após este estādio, sua eficiência declina gradualmente. PARKER et alii (1946) observaram a ação do espectro no controle fotoperiódico da iniciação floral em plantas de dias curtos. Os resultados apontaram ser o comprimento de onda, entre 600 a $680 \mathrm{~nm}$, o mais eficiente na iniciação floral, sendo $720 \mathrm{~nm}$ o limite superior, acima do qual o florescimento é inibido, e apresentando o mínimo de efetividade na região dos 480nm.

A iniciação do primōrdio floral em algumas variedades sob luz contínua mostrou não ser o período de escuridão uma condição necessāria para a iniciação flora1 (BORTHWICK \& PARKER, 1939 e CRISWELL \& HUME, 1972). JOHNSON et alii (1960) estudaram a resposta ao fotoperíodo de diversos cultivares de soja com diferentes maturidades e observaram que tanto na indução floral quanto no desenvolvimento da planta após a indução, os cultivares precoces foram menos influenciados pelo fotoperíodo do que os cultivares tardios. BYTH (1968) comparou a resposta fotoperiódica em cultivares de soja de origem tropical e temperada. A taxa de iniciação floral e o desenvolvimento das plantas foram mais influenciadas pelo fotoperíodo nos cultivares de clima tropical do que nos de clima temperado. Observando tais variações, HARTWIG (1973) enfatizou que um cultivar de soja não poderia ser simplesmente descrito em termos de 
maturação precoce, média ou tardia, sem que esses termos estivessem relacionados à uma latitude específica. Atualmente, a soja é classificada, para os Estados Unidos e Canadā, em 13 Grupos de Maturação: $\quad 000$, $00,0, I$, II, III, IV, V, VI, VII, VIII, IX e X, sendo que os grupos identificados por Indices de valores menores são adaptados à latitudes mais elevadas e os grupos identificados por indices maiores contëm genötipos adaptados às baixas latitudes (próximo do Equador). Os grupos de maturação se diferenciam por intervalos de 10 a 15 dias e são referidos a um ou dois cultivares como padrão.

HARTWIG (1973), relacionando latitude com fotoperiodo, salientou que na transferencia de um cultivar de $15^{\circ}$ para $10^{\circ}$ de latitude existe uma redução de apenas 12 minutos no fotoperiodo; entretanto, quando esta transferência é praticada de $45^{\circ}$ para $40^{\circ}$, há uma redução de 35 minutos. Considerando estas alterações, o autor sugeriu que um cultivar adaptado para produção em baixas latitudes deveria ter uma faixa de adaptação mais ampla do que um cultivar adaptado para produção em latitudes elevadas. Esse é um dos motivos pelo qual, material tardio selecionado no Estado de São Paulo, adapta-se bem a latitudes menores (MIRANDA et alii, 1977).

A importância na disponibilidade de genótipos de soja não sensiveis ou insensiveis a fotoperíodo, foi salientada por CRISWELL \& HUME (1972), POLSON (1972) e SHANMUGASUNDARAM (1979), quanto à utilização dos mesmos em programas de melhoramento para o desenvolvimento de cultivares com maior ärea de adaptação. CRISWELL \& HUME (1972) analisaram 12 cultivares de soja sob fotoperiodos de $12,16,20$ e 24 horas 
em câmara de crescimento. O número de dias da semeadura ao início do florescimento aumentou com fotoperiodos longos em 11 dos 12 cultivares, sendo que os cultiváres precoces foram menos sensiveis que os tardios. Desta forma, 111 linhagens do Grupo de Maturação 00 foram conduzidas sob fotoperiodos de 12, 22, 23 e 24 horas e aproximadamente $70 \%$ das linhagens não tiveram o subperíodo semeadura-florescimento afetado pelo fotoperíodo.

POLSON (1972) testou genótipos de soja dos Grupos 00 e 0 para neutralidade ou insensibilidade ao fotoperíodo com relação à antese. Cerca de 400 linhagens foram avaliadas em casa de vegetação sob diferentes fotoperiodos. Neste experimento, foram identificadas linhagens que floresceram praticamente no mesmo número de dias, sob fotoperíodos com amplitude entre 12 e 22 horas. Värias linhagens identificadas em casa de vegetação como sendo de resposta neutra em relação ao fotoperĩodo, mantiveram o mesmo comportamento em condições de campo sob diferentes fotoperiodos. Algumas destas linhagens sofreram um atraso na maturação, is to devido à exposição das mesmas a fotoperíodos longos.

SHANMUGASUNDARAM \& TSOU (1978) trabalharam com uma linhagem sensível ao fotoperiodo e outra de reação insensível, com o objetivo de determinar o estádio crítico anterior à indução do florescimento e o comportamento da fotoindução necessārios para a antese. Nos tratamentos fotoperiódicos utilizados, 10 e 16 horas, não foram detectadas diferenças na época de florescimento da linhagem insensivel. Entretanto, na linhagem sensivel, o número de dias para o início do florescimento não foi afetado pela troca do fotoperíodo de 16 para o de 10 horas 
atē nove dias após a emergência. Plantas mudadas de fotoperiodo de 10 para 16 horas, não floresceram antes de 36 dias após a emergência, indicando que a indução foi completada 36 dias apös a emergência, sendo que a antese mais precoce ocorreu 46 dias após a emergência. Os autores con cluíram que o período de indução foi de 27 dias curtos (10 horas), que a antese ocorreu 10 dias depois de encerrada a indução do florescimento e que o tempo crítico para se iniciar a indução foi de nove dias após a emergência para a linhagem sensivel. Estes resultados indicaram que a soja possui uma fase juvenil, na qual é insensivel ao fotoperiodo; na linhagem do experimento anterior, este periodo foi de nove dias; poderá ser diferente em outras linhagens.

A variação na resposta fotoperiödica em alguns caracteres da soja foi relatada por SHANMUGASUNDARAM (1979), utilizando fotoperíodos de 10 horas (dias curtos) e 16 horas (dias 1ongos). Entre os 40 cultivares analisados 17 não mostraram diferenças significativas entre os fotoperiodos para todos os caracteres em estudo. 0 número de vagens por planta, dias para maturidade e número de nós por planta foram altamente correlacionados com a produtividade por planta em ambos os fotoperídos. O primeiro nó a florescer, altura da planta no florescimento, dias para oflorescimento, número de nós no florescimento e peso de cem sementes foram menos influenciados pelos fotoperíodos na maioria dos cultivares, enquanto a altura na maturidade, número de nös na maturi dade, número de dias para maturidade e produtividade foram mais influenciados. 
NISSLY et alii (1975) testaram 515 genótipos do Grupo de Maturação III em relação à sensibilidade ao comprimento do dia, sob condições de comprimento do dia natural e dia natural complementado de 5 ho ras com luz incandescente. Os dados mostraram variação muito grande do germoplasma quanto à sensibilidade. Entretanto, PI 317334 B, apresentou um alto grau de insensibilidade a fotoperiodos longos. A diferença foi somente de dois dias no florescimento e de três dias na maturidade quando comparados os dois tratamentos fotoperiódicos. A seleção realiza da em Porto Rico, sob iluminação contínua, mostrou resultados similares aos obtidos nos Estados Unidos. Os genótipos PI 317334 A e PI 196160 apresentaram reação neutra ao comprimento do dia e PI 317334 B mostrou bai xo grau de sensibilidade ao fotoperíodo, em câmara de crescimento, sob períodos de $12,14,16$ e 20 horas de 1 uz.

A reação fotoperiódica que regula o florescimento, aparentemente controla alguma reação básica que é essencial não somente ao florescimento, mas a todos os estädios do desenvolvimento reprodutivo (JOHNSON et alii, 1960). Para esses autores, alguns cultivares são aparentemente mais sensiveis do que outros ao fotoperiodo posterior ao florescimento, encurtando o subperíodo florescimento-maturidade. HARTWIG (1975) procurou identificar genótipos de florescimento tardio, destinados a estações curtas, atravēs da obtenção de maior porte e maior altura de inserção de vagens em cultivares de häbito determinado; PI 171450 e "Hill" quando utilizados como parentais originaram linhagens mais produtivas, que floresciam mais tarde, porém maturavam praticamente junto com os cultivares testemunhas, devido à redução do subperíodo 
florescimento-maturidade. 0 autor salientou que os resultados obtidos tornam possivel a modificação de dias para o início do florescimento sem provocar muita alteração nos dias para completar a maturidade.

\subsection{Efeito da Latitude}

A latitude atua de maneira muito pronunciada nos genótipos de soja. Segundo Ball, citado por HARTWIG (1973), a altura da planta e o número de dias para a maturidade de genótipos introduzidos, foram muito reduzidos quando cultivadós na região da Costa do Golfo em relação aos cultivos realizados em Washington, DC. Os genótipos de soja säo muito sensiveis ao fotoperíodo e esta sensibilidade determina em grau considerāvel a ärea de adaptação e o tempo para maturidade de cada cultivar (HARTWIG, 1970).

WANG et alii (1980) estudando a resposta fotoperiódica em sojas coletadas em localidades de diferentes latitudes na China, observaram que a resposta a dias curtos foi maior em genótipos selvagens do que em material semi-cultivado. Os autores consideraram que as sojas com resposta fraca a dias curtos (precoces) foram originadas daquelas com resposta forte (tardias) e migraram gradualmente de baixas latitudes para regiões de latitudes mais elevadas.

HARTWIG (1970) testou em Mayaguez, Porto Rico $\left(18^{\circ} 14^{\prime} \mathrm{N}\right)$ o comportamento de cultivares de soja adaptados aos Estados Unidos. Quase todos os cultivares floresceram em 30 dias ou menos. O cultivar "Hil1", Grupo V, floresceu no mesmo periodo que "Hardee", pertencente ao Grupo 
VIII. Entretanto, "Hill" alcançou a maturidade 24 dias antes que "Hardee". Is to sugere a existência de variabilidade genética, a qual permite seleção para um periodo relativamente longo entre a emergência e o início do florescimento. O genótipo PI 274454 considerado como um dos mais tardios disponíveis em Stoneville $\left(33^{\circ} 20^{\prime} \mathrm{N}\right)$, iniciou o florescimento em 98 dias quando cultivado no início de junho em Porto Rico $\left(18^{\circ} 14^{\prime} \mathrm{N}\right)$ e quando cultivado na Colômbia $\left(3^{\circ} \mathrm{N}\right)$ floresceu em 65 dias. Outra avaliação sobre a influência da latitude foi realizada em Beltsville por JOHNSON et alii (1960), onde diferentes condições fotoperiódicas foram simuladas para latitudes de $39^{\circ}, 36^{\circ} 40^{\prime}$ e $34^{\circ} 20^{\prime}$. As plantas cresceram sob condições naturais das 8:00 às 17:00 horas e foram colocadas em câmaras escuras onde o fotoperiodo foi complementado. Embora a máxima diferença no fotoperiodo fosse 17 minutos, o tempo médio para o florescimento ou maturidade tornou-se menor com o decrëscimo do comprimento do dia. O nümero médio de dias para a maturidade de seis cultivares plantados em 23 de maio, para latitudes simuladas de $39^{\circ}, 36^{\circ} 40^{\prime}, 34^{\circ} 20^{\prime}$ foi 146, 141 e 139 dias, respectivamente. Para plantio em 4 de junho,os dias para maturidade foram 119,116 e 113, respectivamente.

Ilustrando a magnitude da diferença fotoperiödica em relação à latitude, HARTWIG (1973) ressaltou que em 20 de maio o fotoperío do para latitude de $45^{\circ}$ é uma hora e 40 minutos maior que a $30^{\circ}$ de 1 atitude e é três horas maior que a $10^{\circ}$. Assumindo que um cultivar adaptado esteja disponível para semeadura em 20 de maio (aproximadamente 20 de novembro no Hemisfério Su1), a diferença do fotoperíodo na data de plantio e na maturidade poderia variar de 30 minutos em $10^{\circ}$ atè mais de 3 horas em $45^{\circ}$ de latitude. 
NISSLY et alii (1981) salientaram que genōtipos de soja com maturidade tardia e reação neutra ou quase-neutra ao fotoperíodo, de vem ser um recurso valioso para programas de melhoramento, devido a suas potencialidades de ampla adaptação a diferentes latitudes e estações do ano. A soja è cultivada em muitas partes do mundo, sendo que a maioria das äreas localizam-se em latitudes superiores a $23^{\circ}$. 0 Brasil constitui-se numa exceção porque possui em torno de dois milhões de hectares de soja em latitudes menores que $23^{\circ}$, existindo uma tendência de deslocamento para āreas próximas do equador. (KIIHL et alii, 1985).

VILELA et alii (1979) avaliaram o comportamento de cultivares de soja em cultivo de inverno no cerrado. As linhagens mais tardias Lo 75-1410, Lo 75-2660 e L 109-ICA apresentaram bom desempenho no plantio de inverno quando comparadas com o plantio normal, no que diz respeito à produção de grãos, altura da planta, altura de inserção da pri meira vagem e ciclo. Os autores concluíram que a seleção de material segregante em época de dias curtos, com ênfase às linhagens mais tardias, poderia ser feita visando à obtenção de cultivares menos sensíveis ao fotoperiodo e de possivel adaptação a regiões mais próximas do equador.

A soja cultivada numa latitude menor do que a de melhor adaptação, apresenta porte e rendimento reduzidos devido aos dias curtos, pois as plantas não se encontram suficientemente desenvolvidas quan do atingem o florescimento. Por outro lado, quando plantada numa latitude maior à recomendāvel, os dias mais longos não permitem que ela floresça, mudam o florescimento para fora da época normal, ficando demasiadamente tardia (GANDOLFI et alii, 1977). Quanto a este respeito, 
HARTWIG (1970), sugeriu que sob condições de dias curtos, um mínimo de 45 dias entre a emergência e o início do florescimento é requerido para permitir o desenvolvimento vegetativo necessārio para produzir rendimento razoável e com altura de vagem suficiente para viabilizar a colheita mecanizada sem perdas excessivas.

CREGAN \& HARTWIG (1984) testaram 12 genótipos de soja em fotoperíodos constantes, variando entre 11 a 20 horas, para caracterizar - comportamento de cada genótipo. Em fotoperiodos constantes e menores do que 14 horas, os genótipos PI 274454, PI 159925 e linhagens derivadas de cruzamentos com PI 159925 floresceram significativamente mais tarde em relação aos outros genötipos testados, incluindo os cultivares "Biloxi" e "Jüpiter", que normalmente apresentam maturidade tardia. A regressão de dias para o início do florescimento sobre duração do fotoperiodo foi utilizada para caracterizar a resposta fotoperiódica de cada genótipo. Os mesmos foram classificados em três categorias: aqueles que não respondem, aqueles somente com resposta linear e os que apresentaram respostas linear e quadrätica significativas. Os genótipos caracterizados como de florescimento tardio sob condições de dias curtos mostraram somente resposta linear.

FRANCIS (1970) ressaltou que a eliminação da sensibilidade ao fotoperiodo é um objetivo dos programas de melhoramento modernos, pois é um fator que pode ser limitante na adaptação de novos cultivares às diferentes latitudes. Em trabalho realizado para as condições brasileiras, KIIHL et alii (1982) obtiveram o cultivar "Tropical", proveniente do cruzamento Hampton X $570-51$, sendo que E 70-51 era uma 
linhagem $\mathrm{F}_{4}$ selecionada a partir do cruzamento Hill X PI 240664. "Tropical" é um cultivar adaptado às baixas latitudes, apresentando ciclo de 115 a 125 dias para ăreas entre zero e $15^{\circ}$ de latitude. Outro cultivar desenvolvido no Brasil para regiões de baixa latitude foi BR-9 (Savana), sendo resultado de seleção em "Bulk" formado por cruzamentos entre "Davis" com Santa Rosa, IAC 73-481, IAC 73-1075 e F 67-5221 (SOUZA et alii, 1984)

\subsection{Temperatura}

A interação entre o comprimento do dia e a temperatura exerce uma importante influência sobre algumas espēcies. O fator comprimento do dia é essencialmente constante entre os anos, enquanto a temperatura è geralmente variāvel. A primeira observação mostrando que a resposta ao comprimento do dia é modificada pela temperatura, foi relatada por GARNER \& ALIARD (1930). Os autores obtiveram evidências indicando que sob condições de campo em Washington, DC, as variações de ano para ano na data de florescimento, em cultivares precoces e tardios de soja plantados em qualquer data, ocorreram principalmente devido a diferenças na temperatura, enquanto o comprimento do dia foi o principal fator externo responsável pelo fato de um cultivar ser sempre relativamente precoce e outro tardio para atingir o estádio reprodutivo.

A temperatura noturna é um importante fator que afeta a indução floral, bem como outras reações nas plantas (ROBERTS, 1943). Sua influência alterou a morfologia da cultura (THOMAS \& RAPER JUNIOR, 1978). 
Segundo Summerfield et alii, citados por THOMAS \& RAPER JUNIOR (1978), um aumento da temperatura noturna promoverā redução no tempo para florescimento de certos cultivares de soja e, à medida que a planta matura, um aumento na temperatura diurna provocará redução na produtividade. Também ressaltaram que para alguns cultivares adaptados aos trópicos, uma alteração de $5^{\circ} \mathrm{C}$ na temperatura noturna è mais eficiente que uma alteração de 100 minutos no comprimento do dia, no que se refere à influên cia sobre o início do florescimento. SCHAIK \& PROBST (1958) estudando - efeito dos fatores ambientais na produção de flores e na eficiência reprodutiva da soja, observaram que a porcentagem de flores e vagens abortadas aumentou devido às altas temperaturas e aos fotoperíodos longos.

LAWN \& BYTH (1973) concluíram que a temperatura apresentou uma influência significativa somente nos cultivares menos sensiveis ao fotoperíodo. As fases de pré-florescimento mais longas, para cultivares de maturidade precoce plantados antecipadamente, estão associadas com temperaturas diärias mais baixas ocorridas nosubperíodo emergência-floração. Em trabalho realizado no Sul do Canadā, MAJOR et alii (1975), observaram que baixas temperaturas e dias longos determinam efeitos aditivos no retardamento do florescimento. Os efeitos das baixas temperaturas predominavam no inicio da primavera e nos dias longos próximo ao inicio do verão. Por outro lado, a maturidade foi apressada de tal forma pelos dias curtos do outono, que superavam os efeitos de retardamento das baixas temperaturas dessa estação sobre o amadurecimento das plantas. 
A alteração em $5^{\circ} \mathrm{C}$ da temperatura noturna mantida por todo o período de crescimento influenciou o desenvolvimento vegetativo de alguns cultivares de caupi e soja. O fotoperíodo e a temperatura noturna influenciaram o tempo para o início do florescimento, entretanto, a taxa de desenvolvimento vegetativo foi mais dependente da temperatura noturna em relação a diurna e ao comprimento do dia (HUXLEY \& SUMMERFIELD, 1974). A importância da temperatura noturna foi enfatizada por SEDDIGH \& JOLLIFF (1984) como um critério em potencial para o desenvolvimento de novos cultivares de soja.

De acordo com BOARD \& HALL (1984), a maior razão para a redução da produtividade em plantios realizados em datas não recomendadas é o desenvolvimento inadequado devido ao florescimento prematuro. Dependendo da temperatura e de outras condições ambientais, $\bar{e}$ necessārio um período vegetativo de 42 até 58 dias para promover um indice de área foliar em torno de 3,0 que è requerido para produtividades elevadas (CONSTABLE, 1977; HARTWIG, 1970; HUXLEY \& SUMMERFIELD, 1974; SCHAIK \& PROBST, 1958; THOMAS \& RAPER JUNIOR, 1977). Respotas morfológicas em soja foram avaliadas por THOMAS \& RAPER JUNIOR (1977) sob fotoperíodos curtos e longos, em diferentes combinações entre temperaturas diurnas e noturnas. 0 desenvolvimento de ramos axilares em nós mais baixos do caule principal variou com a temperatura e com o estádio de desenvolvimento na indução. Para iniciação floral foram relacionados três sítios potenciais: nós do caule principal, ramos axilares e nós dos ramos axilares. As variações nas razões entre mëdias de flores/nós e vagens/nós, evidenciaram a importância da idade da planta e da temperatura em alterar a resposta fotoperiódica da soja. 
As influências da temperatura e do fotoperíodo na redução da produtividade da soja, por florescimento prematuro em datas não recomendadas, foram estudadas por BOARD \& HALL (1984). Os resultados observados mostraram que temperaturas altas $\left(27^{\circ} \mathrm{C}\right)$ e fotoperíodos curtos reduziram o período vegetativo, enquanto temperaturas menores $\left(21^{\circ} \mathrm{C}\right)$ e fotoperiodos longos prolongaram o mesmo. Interação significativa foi detectada entre fotoperíodo e temperatura no caráter tempo para o início do florescimento. Os autores concluíram que esta interação foi devida ao maior efeito de temperaturas altas em diminuir o período vegetativo sob dias curtos em relação aos dias longos.

Os resultados obtidos por POLSON (1972) indicaram que algumas linhagens podem ser sensiveis à temperatura e que esta sensibilidade era controlada geneticamente. As linhagens identificadas como neutras ao comprimento do dia foram geralmente insensiveis à temperatura. Diferentes termoperiodicidades sobre o desenvolvimento de cultivares de soja, sob condições de dias curtos no Rio Grande do Sul, foram estudadas por GANDOLFI et alii (1979). O trabalho foi realizado em câmara clí mática para avaliar os termoperiodos de $30^{\circ} / 30^{\circ}, 30^{\circ} / 24^{\circ}, 24^{\circ} / 24^{\circ}$ e $24^{\circ} / 18^{\circ}$ (dia/noite). As anälises demonstraram haver diferenças significativas na resposta. da maioria dos cultivares, com relação aos caracteres: nümero de dias da emergência ao florescimento, comprimento do cau le principal, nümero de nōs do caule principal e nümero de folhas da plan ta. De uma maneira geral, os cultivares apresentaram tendência a prolongar o periodo vegetativo, tanto sob altas como em baixas temperaturas. Os cultivares que mostraram menor influência do termoperíodo sobre 
o nümero de dias da emergência à floração foram: PI 307838, IAS-4, Santa Rosa e UFV-1.

\subsection{Epoca de Plantio}

Devido ao fato de os genótipos de soja não serem suscetíveis ao mesmo comprimento de dia critico, WHIGHAM \& MINOR (1978), salientaram que - efeito da data de plantio sobre o número de dias para o florescimento e dias para a maturidade deve ser distinto para os diferentes cultivares.

HARTWIG (1954) estudando os fatores que afetam a época de plantio da soja em Stoneville $\left(33^{\circ} 20^{\prime} \mathrm{N}\right)$, reportou que o comprimento do dia, a temperatura do solo e a umidade, foram os principais determinantes da época adequada. O tempo entre a emergência e o florescimento não apresentou variação para os cultivares precoces, sendo o mesmo aproximadamente de 30 dias, independentemente da época de plantio. Entretanto, para a variedade com maturidade tardia "Roanoke", foram requeridos 47 dias para o início do florescimento quando plantada em 10 de abril e 63 dias no plantio em 01 de maio. Quanto à data de maturidade foram observados atrasos significativos nos cultivares precoces devido ao retardamento do plantio, enquanto que nos tardios, a variação foi de menor magnitude. Oplantio antecipado(abri1) reduziualtura dos cultivares tardios, sendo a redução atribuỉda ao florescimento precoce sob condições de dias curtos e também a uma menor taxa de crescimento provocada por baixas temperaturas do solo. Estudos têm sido conduzidos nos quais foi demonstrado que a soja emerge e cresce mais rapidamente quando a 
temperatura minima do solo atinge ou excede $18,3^{\circ} \mathrm{C}$ (HARTWIG, 1958).

ABEL JUNIOR (1961) reportou que o atraso no plantio reduziu em $50 \%$ o tempo entre oflorescimento e a maturidade nos cultivares precoces, enquanto que a fase de pré-florescimento foi diminuỉda nos tax dios. Os cultivares de ciclo médio apresentaram redução nas fases de pré e pós-florescimento pelos dias curtos. A data de maturidade dos cul tivares tardios mostra-se menos influenciada pela data de plantio que nos precoces (ABEL JUNIOR, 1961; HARTWIG, 1954, 1958; OSLER \& CARTTER, 1954).

JOHNSON et alii (1960) observaram o efeito relativo de pequenas diferenças fotoperiódicas em soja, tais como ocorrem em diferentes latitudes ou como conseqüência das variações nas datas de plantio. Interações significativas entre cultivares e fotoperiodos e entre cultivares e datas de plantio foram detectadas para a maioria dos caracteres. Simulando a mudança no comprimento do dia devido à troca de estação do ano, com fotoperíodo variando dia a dia, foram observadas diferenças no periodo entre a emergência e a maturidade. Entretanto, as maiores diferenças foram estabelecidas durante o periodo entre a emergência e o florescimento.

o fotoperíodo tem uma influencia direta sobre a iniciação floral em muitas espécies; com isso, o comprimento do dia durante os estädios iniciais de desenvolvimento da cultura, ē um importante fator na determinação da data de plantio (FRANCIS, 1970). Quanto à influência do fotoperíodo sobre os subperíodos do prë ao pös-florescimento, LAWN \& BYTH (1973) observaram que os cultivares de maturidade mais precoces 
eram neutros ao comprimento do dia e apresentavam resposta significativa ao fotoperiodo somente durante o florescimento, enquanto que os cultivares tardios foram sensiveis ao fotoperiodo durante as fases de préflorescimento e de florescimento, sendo que a fase de pós-florescimento foi retardada até a ocorrência de dias mais curtos.

Os efeitos da data de plantio foram avaliados em sete cul tivares de soja em latitude $30^{\circ} 13^{\prime} \mathrm{s}$ por CONSTABLE (1977). Os dados mostraram que a taxa média de redução na produtividade foi de $8 \%$ para cada semana de atraso no plantio. O peso das sementes foi levemente reduzido com o plantio no cedo, porém não houve efeito consistente da data de plantio sobre o número de sementes por vagem. O número de nós por planta também foi reduzido com o atraso do plantio. De acordo com SHANMUGASUNDARAM \& TSOU (1978), nos trópicos e sub-tröpicos, o comportamento do florescimento poderá variar entre cultivares plantados no mes mo local durante diferentes épocas do ano, mesmo que o fotoperíodo seja similar no plantio. Exemplificando, em $15^{\circ} \mathrm{N}$ de latitude, um cultivar plantado em 21 de março e 23 de setembro terā um fotoperíodo de 12 horas. Após o plantio, o experimento plantado em março terá acréscimos fotoperiódicos, enquanto o fotoperíodo para setembro serä reduzido.

FARIAS NETO (1987) relatou que a incorporação de genes pa ra período juvenil longo nos cultivares, pode ser uma estratégia promissora para sobrepujar a interação pronunciada entre o comportamento dos genótipos e as épocas de cultivo, de maneira a tornar possível que um mesmo genótipo tenha comportamento superior e relativamente estävel em épocas diferentes de cultivo. 
CHIPALA (1985) avaliou o comportamento de genótipos que apresentam o caräter periodo juvenil longo, em diferentes épocas de plan tio para ambientes tropicais. Os genótipos com período juvenil floresceram e maturaram mais tarde e foram maiores que as testemunhas. Além disso, foram os mais produtivos em sete ambientes estudados; a amplitude observada no florescimento, maturidade e altura de planta indicaram a existência de variabilidade suficiente para este carāter, com possibilidade de seleção para ambientes específicos.

FARIAS NETO (1987), analisando o comportamento e a variabilidade de genótipos de soja em cultivos de verão e inverno, em Piracicaba-SP, concluiu que as épocas de cultivo influenciaram a duração dos estádios de desenvolvimento dos cultivares, provocando reduções maiores no tempo para florescimento e menores no período reprodutivo dos cultivares no inverno. Também salientou que o nümero de dias para o florescimento e a altura da planta no florescimento são caracteres importantes em programas de melhoramento para maior produtividade em cultivo de inverno ou em baixas latitudes.

\subsection{Insensibilidade}

A identificação de insensibilidade fotoperiōdica ē de grande interesse no desenvolvimento de cultivares com ampla faixa de adaptação. MIYASAKA et alii (1970) avaliaram o desempenho de 200 genötipos de soja, com relação ao fotoperiodismo e às temperaturas baixas. o comportamento dos cultivares Santa Maria-1 e Aliança Preta-1, revelou a existência de genótipos indiferentes ao fotoperiodismo e tolerantes às 
temperaturas baixas.

o comportamento de cultivares dos Grupos I até V, sob diferentes condições termo-fotoperiódicas, foi observado por MAJOR et alii (1975); os resultados mostraram que a maior diferença entre os genótipos foi devida à sensibilidade ao comprimento do dia no período de florescimento. Também relataram que os cultivares de maturidade tardia foram mais sensiveis ao fotoperiodo que os cultivares precoces, concordando com observações anteriores de BYTH (1968), CRISWELL \& HUME (1972) e JOHNSON et alii (1960).

Para avaliar plantas $F_{2}$, SHANMUGASUNDARAM \& WANG (1977), desenvolveram uma técnica para selecionar genótipos insensiveis ao fotoperiodo. Quanto a este carāter, foram utilizadas três alternativas: enraizamento de ramos, enxertia sobre garfo comum a ambas e decapitação. Os genōtipos PI 194647 e PI 248407 (insensíveis) e uma linhagem pura de PI 86736 (sensível) foram os testadores. 0 enraizamento de ramificações e a enxertia não deram resultados satisfatórios. Por outro lado, a técnica da decapitação para provocar a formação de duas hastes por planta, permitindo diferentes tratamentos fotoperiódicos, foi considerada eficiente na identificação de plantas sensíveis e insensíveis, possibilitan do também o estudo da herança desse carāter. Tendo como objetivo identificar para condições de baixas latitudes os cultivares de soja menos sensiveis, GANDOLFI et alii (1977) avaliaram 555 genötipos pertencentes aos Grupos tardios VII, VIII, IX e X. A maioria dos genótipos estudados mostraram sensibilidade marcante ao fotoperíodo em relação às seguintes caracteristicas: número de nōs, comprimento do caule principal e número 
de folhas trifolioladas da planta. De modo geral, os genótipos testados apresentaram diferenças significativas somente para 14 horas de luz, quando comparados com 10 e 12 horas. Os genótipos PI 85416 e PI 95960 , originários da Coréia e pertencentes ao Grupo VII, não diferiram em comportamento nos três fotoperíodos, sendo considerados como os menos sensíveis em relação ao tempo necessärio para o inicio do florescimento.

SHANMUGASUNDARAM (1978) relatou a variação na resposta fotoperiódica no florescimento da soja, utilizando dia normal, fotoperíodo curto e longo. Genótipos de dez Grupos de Maturação foram avaliados em condições de campo e foram observados diferentes graus de atra so no florescimento sob dias 1ongos. Dez classes foram empregadas para distinguir os genótipos de acordo com a sensibilidade. As classes de 0 a 1 corresponderam aos genōtipos insensiveis, enquanto que 8 e 9 ao mäximo de sensibilidade. Os genótipos precoces apresentaram menor sensibilidade que os tardios, porēm, foram identificados alguns genótipos tar dios com baixa sensibilidade, os quais foram indicados como promissores para programas de melhoramento em regiões tropicais. Outro estudo sobre sensibilidade para tempo de florescimento e maturidade foi relatado por NISSLY et alii (1981), para. Iinhagens do Grupo III, em experimentos realizados em Illinois $\left(40^{\circ} \mathrm{N}\right)$ e Porto Rico $\left(18^{\circ} \mathrm{N}\right)$. Os genótipos foram submetidos ao comprimento de dia natural, fotoperiodo continuo e fotoperíodo de 19 horas, obtidos por suplementação com luz incandescente. As 1inhagens submetidas a fotoperiodos longos eventualmente floresceram, porëm mostraram grande amplitude de atraso no florescimento, comparadas com as conduzidas sob dia normal. Os autores identificaram 32 linhagens 
com baixa sensibilidade ao fotoperíodo e uma delas, PI 317334 B praticamente não exibiu sensibilidade nos dois ambientes.

\subsection{Herança}

SINGH \& ANDERSON (1949) estudaram a herança da maturidade em soja, utilizando gerações $F_{2}$ e $F_{3}$ de seis cruzamentos diferentes. Existiram evidências de que a maturidade da soja é influenciada por poucos genes maiores e alguns genes menores. A segregação transgressiva em direção à maturidade tardia obtida em $F_{3}$ na maioria dos cruzamentos foi atribuỉda à influência da complementação de genes para marutidade tardia nos parentais. BERNARD (1971) reportou dois pares de genes independentes, denominados $E_{1} / e_{1}$ e $E_{2} / e_{2}$, os quais afetam $\circ$ tempo para florescimento e a maturidade da soja. A herança do tempo para florescimento em soja sob condições de dias longos foi relatada por BUZZELL (1971), on de as plantas foram submetidas a fotoperíodos de 20 horas com luz fria fluorescente. No controle da resposta ao florescimento foi encontrado um gene maior com dois alelos. 0 alelo dominante $\left(E_{3}\right)$ apresentou resposta sensível pelo atraso observado no florescimento e na maturidade, en quanto que o alelo recessivo $\left(e_{3}\right)$ teve resposta insensivel, apresentando maturidade precoce.

BUZZELL \& VOLDENG (1980) sugeriram a denominação $E_{4} / e_{4}$ para a resposta ao florescimento em dias longos com luz incandescente. Os autores obtiveram evidências de que um ünico gene recessivo controla. a insensibilidade. Recentemente, $010 c 0 E_{5} / e_{5}$ foi descrito por McBLAIN \& BERNARD (1987), sendo que $\mathrm{E}_{5}$ ocasiona atraso na maturidade. 
KIIHL (1976) constatou que o cultivar Santa Maria tem, aparentemente, um período juvenil que é responsāvel por seu bom desenvolvimento, ainda que sob condições de comprimento de dia mais curto que o seu valor crítico máximo. Observou que, cultivares com o caräter florescimento tardio, poderiam ser adaptados em āreas e épocas do ano onde os demais floresceriam muito cedo e alcançariam pouca altura na maturidade. Concluiu também, que o controle de dias longos e dias curtos é diferente e, que o"caräter florescimento tardio é geneticamente controlado" e pode ser transferido em programas de melhoramento conduzidos sob condições de dias curtos. SHANMUGASUNDARAM (1978), utilizando a técnica da decapitação, estudou a herança do florescimento em fotoperíodo de 10 e 16 horas, com os cultivares "Shih-Shih", PI 194647, PI 230970, PI 230971 e uma 1inhagem pura de PI 86736. Em 10 horas, o $F_{1}$ foi precoce em todos os casos, sendo dominante o florescimento precoce nesse periodo; $\quad \mathrm{F}_{2}$ confirmou esse resultado. Entretanto, sob 16 horas, $0 F_{1}$ apresentou dominância parcial para florescimento tardio e o $F_{2}$ uma distribuição continua. O autor salientou que sob 16 horas de luz, o gene maior que age sobre o número de dias para o florescimento $\bar{e}$ modificado por uns poucos genes menores ou pela interação com outros genes.

HARTWIG \& KIIHL (1979) indicaram que o controle genético de dias para o florescimento sob condições de dias curtos, no cruzamento D 72-7842 X Santa Maria, foi diferente do observado em dias 1ongos. o caräter florescimento tardio sob condições de dias curtos é recessivo e é controlado relativamente por poucos genes. Os autores consideraram que três locos podem estar envolvidos. 
TISSELI JUNIOR (1981) estudou a herança do carāter período juvenil longo sob condições de dias curtos e longos. Este carāter foi recessivo para os cultivares PI 159925 e FC 31919. A segregação transgressiva observada na população $F_{2}$ do cruzamento entre esses cultivares e a estimativa do número de genes indicaram que os mesmos possuem genes diferentes para o carāter, ocorrendo no mínimo dois genes diferentes para juvenilidade. De acordo com as estimativas do número de genes, "Davis" diferiu na resposta ao florescimento, sob condições de dias curtos, de "Tracy" e de PI 159925 por um gene e de FC 31919 por cinco genes. "Tracy" diferiu de PI 159925 por dois genes. O autor salientou que "Davis" e PI 159925 poderiam compartilhar um fator comum para periodo juvenil longo. Altas estimativas de herdabilidade e do ganho gene-tico esperado para este caráter, sob condições de dias curtos, poderiam justificar a prätica de seleção para o mesmo em populações segregantes. PI 159925 foi indicado como um germoplasma promissor para obtenção de progênies adaptadas às condições tropicais.

A herança do nümero de dias para florescimento foi estudada por GILIOLI et alii (1984) em quatro mutantes naturais sob condif̧ões de dias curtos. Para as avaliações foram utilizados os seguintes cruzamentos: Paranā X Paranagoiana; São Luiz X PR 77-10001; Viçoja X UFV-1 e "Hardee" X IAC 73-2736-10. Os genótipos Paranagoiana, PR 77-10001, UFV-1 e IAC 73-2736-10 são de florescimento e maturidade tar dios e oriundos de mutações gênicas naturais ocorridas nos genótipos Paranā, São Luiz, Viçoja e "Hardee", respectivamente. 0 teste do $\chi^{2}$ aplicado às populações $F_{2}$ e $F_{3}$ de todos os cruzamentos estudados, exceto Viçoja X UFV-1, indicou ausência de significância ao nível de $5 \%$ para 
segregação de genōtipos precoces e tardios, na proporção $3: 1$. Os resultados indicando que os genōtipos tardios são controlados por um alelo recessivo foram coerentes, exceto para UFV-1, com os obtidos sob condições de dias longos, em que foi constatado um alelo recessivo controlando o número de dias para oflorescimento nos genótipos mutantes Paranagoiana, PR 77-10001, IAC 73-2736-10 e UFV-1. Os autores salientaram que em um programa de melhoramento utilizando Paranagoiana, PR 77-10001 e IAC 73-2736-10 como fonte de genes, a seleção de genótipos tardios poderá ser aplicada igualmente em dias com 10 a 13 horas de luz.

KIIHL et alii (1985) avaliaram cinco genótipos com florescimento tardio (Paranagoiana, BR 80-7553, Tropical, Santa Maria e PI 159925) e verificaram que o florescimento tardio desses genótipos foi devido à combinação de um período juvenil longo e um período maior entre o início da indução até a abertura das flores.

\subsection{Heterose e Heterobeltiose}

0 cruzamento entre individuos notadamente não aparentados resulta em descendentes mais vigorosos. Esse fenômeno è denominado vigor de hỉbrido, sendo que o termo heterose corresponde a essa manifestação do vigor de híbrido. Do ponto de vista prätico, tem interesse o vigor de híbrido quando este é comparado ao parental melhor, tal comparação ē denominada heterobeltiose (PATERNIANI, 1974).

WENTZ \& STEWART (1924) relataram evidências de vigor de híbrido para produtividade dos híbridos sobre os parentais com amplitude 
de 59,58 a 394,37\%. VEATCH (1930) detectou heterose em värios caracteres, destacando-se os valores obtidos para produtividade, altura de planta e número de dias para o florescimento, com médias de 35,47, 15,04 e 7,92\%, respectivamente. A comparação com o parental superior também foi realizada apresentando médias de $19,55,2,07$ e $0,64 \%$, respectivamente. CHAUDHARY \& SINGH (1974) observaram heterose para a maioria dos caracteres estudados, exceto para número de dias para 0 florescimento $(-0,9 \%)$ e tamanho das sementes $(-1,6 \%)$. Os caracteres número de sementes por planta, produção de sementes por planta e número de vagens por planta apresentaram heterose de $57,2,59,9$ e $55,1 \%$, respectivamente. A heterobeltiose para produtividade variou de $-30,3$ a $67,8 \%$ com mëdia de 26,1\%. Os autores ressaltaram que a heterose para produtividade pode estar relacionada com os efeitos aditivos dos componentes da produtividade.

PASCHAL II \& WILCOX (1975) avaliaram genōtipos exōticos (China e Coréia) e cultivares melhorados nos Estados Unidos em esquema dialélico parcial. A heterose e a heterobeltiose apresentadas por parentais de mesma origem foram 16,4 e $9,4 \%$, respectivamente, valores estes levemente superiores aos valores de heterose e heterobeltiose relativos aos parentais de origens diferentes (mëdias de 15,5 a 7,0\%, respectivamente). Esses autores indicaram que o caräter peso da planta è talvez melhor testador da heterose do que a produtividade. Para esse caräter a mesma relação foi mantida, ou seja, os parentais de mesma origem mostraram-se superiores $(15,1$ e $7,7 \%)$ em relação aos de origem diferente $(14,5$ e $6,4 \%)$. Embora os parentais utilizados no estudo fossem 
supostamente distintos geneticamente, a heterose para produtividade e outros caracteres não foi significativa.

A heterose e a heterobeltiose parecem não ser bons critërios para predizer o potencial de um cruzamento (WEISS et alii, 1947; LEFFEL \& HANSON, 1961). Porēm, em ambos os casos, o espaçamento utilizado para avaliar as plantas $\mathrm{F}_{1}$ foi maior que o convencional. CHAUHAN \& SINGH (1982) avaliaram $20 \mathrm{~F}_{1}$ 's e 17 populações em $F_{2}$ envolvendo parentais com alta, moderada e baixa divergência genética, com o objetivo de encontrar uma relação entre divergência genêtica dos parentais com a heterose na geração $F_{1}$ e a variabilidade genética na geração $F_{2}$. As progênies com moderada e alta divergência dos parentais mostraram heteroses superiores às de baixa divergência, com poucas exceções. Progênies $F_{1}$ que exibiram heteroses superiores apresentaram maior variabilidade em $F_{2}$ e foi evidenciada a relação entre heterose e variabilidade para produtividade. Os autores salientaram que a diversidade genëtica parece ser essencial para a manifestação da heterose; entretanto, os dados foram insuficientes para correlacionar de forma definitiva divergência genétí ca e heterose.

Para que a utilização de hỉbridos em soja seja viāvel, dois requisitos devem ser atendidos: a) um método para obtenção de sementes hỉbridas em larga escala; b) existência de heterose para produtividade (KUNTA et alii, 1985). Esses autores verificaram heterose para vārios caracteres, sendo que a média para produtividade, número de va gens por planta, peso da planta e altura da planta foram $24,6, \quad 18,0$, 19,5 e $13,5 \%$, respectivamente. A heterobeltiose para os mesmos caracteres 
foram, respectivamente, $20,1,6,9,14,0$ e 7,6\%. Os híbridos apresentaram maior estabilidade que os parentais para produtividade, número de vagens por planta, nümero de sementes por planta e tamanho de sementes, quando analisadas as interações com anos para os dois grupos. Outro fator que dificulta o uso comercial de hïbridos $F_{1}$ de soja é a pequena dis persão dos grãos-de-pólen. 


\section{MATERIAL E METTODOS}

Dez genötipos de soja (Glycine max (L.) Merri11), compreendendo cultivares comerciais e linhagens experimentais, foram deliberadamente escolhidos para esse estudo. Os genótipos utilizados como parentais foram: Cristalina, EMGOPA-301, IAC-4, IAC-5, IAC-6, IAC-8, IAC-9, IAC-11, Santa Rosa e SS-1. Os genótipos Cristalina, IAC-8, IAC-9 e IAC-11 são os mais recomendados para cultivo de inverno em são Paulo. Os outros genótipos foram selecionados com base no comportamento superior em testes conduzidos pelo Setor de Genética Aplicada às Espécies Autógamas do Instituto de Genética da Escola Superior de Agricultura "Luiz de Queiroz", da Universidade de São Paulo, durante dois anos, em três locais contrastantes.

Os experimentos foram conduzidos em ärea experimental do Departamento de Genética da ESALQ, no município de Piracicaba-SP, situado a $22^{\circ} 42^{\prime} 30^{\prime \prime}$ de latitude sul, $47^{\circ} 38^{\prime} 00^{\prime \prime}$ de longitude oeste e a $537 \mathrm{~m}$ de altitude em relação ao nível do mar. 0 solo dessa área é do tipo terra roxa estruturada - série "Luiz de Queiroz" 
(RANZANI et alii, 1966). A duração do comprimento do dia, temperaturas média, máxima e mínima, umidade relativa e precipitação pluvial durante o periodo experimental, encontram-se no Apêndice 1.

Os parentais foram selecionados devido ao fato de apresentarem tolerância às variações do fotoperiodo (período juvenil), níveis altos de produtividade e certa divergência genética constatada no exame de genealogias (HIROMOTO \& VELLO, 1986; VELLO et alii, 1988).

\subsection{Procedimentos Experimentais}

3.1.1. Obtenção de sementes $F_{1}$

Durante o outono de 1986 , os dez genótipos parentais foram plantados em vasos de cerâmica e cultivados em telado. Os parentais foram classificados atravēs de caracteres qualitativos (cor do hipocótilo, cor das flores, cor das vagens, cor da pubescência, häbito de cres cimento e cor de hilo) para uso futuro como marcadores visando separar cruzamentos de autofecundações indesejāveis. No inicio do inverno de 1986, os dez genótipos parentais foram novamente plantados em vasos de cerâmica e cultivados em telado, como também sob condições de campo. Estes plantios foram realizados em diferentes épocas, de forma que não hou vesse defasagem da época de florescimento, fato este que poderia prejudicar a obtenção das sementes hïbridas desejadas.

As plantas do telado foram utilizadas, preferencialmente, como parental feminino nos cruzamentos; quando estas plantas apresentaram 
excesso de flores, parte destas flores foram utilizadas também como parental masculino. As plantas instaladas em condições de campo foram utilizadas somente como fonte de pólen para os cruzamentos. A coleta das flores foi realizada no período matinal, armazenando-se em vidros con tendo silica, que foram lacrados e acondicionados em geladeira; no periodo da tarde, estas flores foram utilizadas nas hibridações com plantas cultivadas em telado.

Para completar o esquema dialélico com os dez ( $n$ ) parentais, excluindo-se os recíprocos, num total de $(n(n-1) / 2)=45$ cruzamentos, foram conduzidos outros três lotes de cruzamentos, em três épocas distintas, sendo que o primeiro foi instalado na segunda quinzena de outubro. O segundo lote foi instalado 15 dias após e o terceiro lote 30 dias em relação ao primeiro.

\subsubsection{Obtenção de sementes $\mathrm{F}_{2}$}

As sementes $F_{1}$ obtidas na primeira etapa (1986) foram semeadas em copos plásticos e em torno de oito dias após a emergência as plântulas foram transplantadas para condições de campo. A eficiência deste avanço foi prejudicada por granizo que ocorreu em fevereiro de 1987. As sementes $\mathrm{F}_{2}$ obtidas foram armazenadas em cāmara seca.

As sementes $F_{1}$ obtidas na segunda etapa (inicio de 1987) foram semeadas em copos plästicos e em torno de oito dias após a emergência as plântulas foram transplantadas para sacos de polietileno e cul tivadas em condições de telado. A utilização de telado foi necessária 
para evitar o risco de granizo, como aconteceu na primeira etapa.

O substrato usado nos copos plásticos e nos sacos de polietileno compreendeu uma mistura de terra e esterco na proporção de $2: 1$. As plantas receberam nümeros para identificação de cada semente $F_{1}$, visando-se a observação quanto à expressão de genes marcadores como cor de flor, häbito de crescimento, cor da pubescência e cor da vagem, sendo possivel discriminar cruzamentos de possiveis autofecundações indesejaveis. As plantas que não expressaram o gene marcador do cruzamento foram descartadas. As sementes $F_{2}$ da segunda etapa foram colhidas, devidamente identificadas e acondicionadas em câmara seca.

As sementes $\mathrm{F}_{2}$ obtidas nas duas etapas foram utilizadas nos experimentos para coleta dos dados experimentais.

\subsubsection{Delineamentos e descrições dos experimentos}

Devido à grande variação no nümero de sementes disponiveis entre os cruzamentos, decidiu-se instalar três experimentos: o experimento 1 envolveu todos os cruzamentos e conservou o esquema dialelico; os outros dois experimentos possuiam menor nümero de tratamentos e foram constituídos por cruzamentos com maior disponibilidade de sementes. Os três experimentos encontram-se descritos abaixo:

Experimento 1: este experimento foi composto por todos os cruzamentos possiveis, exceto pelo cruzamento entre EMGOPA-301 x IAC-5, no qual não foi possível a obtenção de sementes $F_{2}$. 
o esquema dialélico foi mantido e o experimento delineado em reticulados quadrados (lätice) $8 \times 8$ com cinco repetições. 0 experimento constou de 64 tratamentos, sendo dez parentais, 44 progênies $F_{2}$ e dez progênies $F_{2}$ adicionais. A parcela experimental foi representada por nove plantas, utilizando-se covas individuais para avaliação. O espaçamento entre covas foi de $0,60 \mathrm{~m}$ com caminhos de $1,20 \mathrm{~m}$ entre parcelas, sen do a área total da parcela de $5,76 \mathrm{~m}^{2}$.

Experimento 2: este experimento constou de 39 tratamentos, sendo 30 progenies $F_{2}$ e nove parentais. A parcela foi composta por uma fileira com 1,0m de comprimento. o espaçamento entre fileiras foi de $0,60 \mathrm{~m}$ e foram semeadas 25 sementes por metro linear de sulco. Aos 25 dias pós-semeadura foi realizado um desbaste para 16 plantas por metro linear. Foi utilizado o delineamento em blocos casualizados com quatro re petiçöes.

Experimento 3: o terceiro experimento foi constituido por 19 tratamentos, sendo dez progênies $F_{2}$ e nove parentais. A parcela foi composta por uma fileira de $3,0 \mathrm{~m}$ de comprimento. 0 espaçamento entre fileiras foi de $0,60 \mathrm{~m}$ e foram semeadas 75 sementes por 3,0 metros $1 \mathrm{i}-$ neares de sulco. Aos 25 dias pós-semeadura foi realizado um desbaste para 48 plantas por 3,0 metros lineares. Foi utilizado o delineamento em blocos casualizados com quatro repetições.

Os experimentos 2 e 3 foram conduzidos paralelamente ao experimento 1 , com o objetivo de realizar comparações entre o desempenho dos cruzamentos nos diversos tipos de parcelas. Além da disponibilidade de sementes dos mesmos, outra razão considerada é que o material expe- 
rimental foi constituĩdo de sementes $F_{2}$, ou seja, geração em que se dispõe de maior segregação. em espécies autógamas.

Para a instalação dos três experimentos foram realizadas uma aração e duas gradagens, adubação com a mistura NPK 3-15-15, no sulco e na cova, dependendo do ensaio. As sementes foram tratadas com fungicida (Captan) e inoculadas (Rhizobium japonicum), visando garantir a ger minação das sementes. A instalação dos experimentos foi realizada em 21/01/88 e a disponibilidade de ägua foi completada com irrigações periódi cas, sempre que se fizeram necessärias.

\subsubsection{Caracteres avaliados}

As observações foram realizadas nas plantas individuais devidamente etiquetadas. As etiquetas foram distribuĩas logo apōs o desbaste, enquanto as plantas apresentavam-se uniformes. Os dados coletados foram os seguintes:

$$
\text { NDF - nümero de dias para o início do florescimento. }
$$

Correspondente ao período entre a data de semeadura até a antese da primei ra flor.

NIF - nümero de internódios na haste principal no início do florescimento. Contados a partir do nó cotiledonar até o äpice da haste principal.

APF - altura da planta (cm) no início do florescimento. Compreendeu a distância entre o colo e a inserção da inflorescência mais distal da haste principal. 
NDM - número de dias para maturidade. Correspondente ao período entre a data de semeadura até aproximadamente $95 \%$ das vagens apresentarem-se maturas.

NIM - nümero de internódios na maturidade. Contados a partir do nó cotiledonar até o āpice da haste principal.

APM - altura da planta na maturidade. Compreendeu a distância entre o colo e a inserção da vagem mais distal da haste principal.

ACM - acamamento. Avaliado na maturidade através de uma escala de notas visuais variando de 1 a 5 , onde a nota 1 correspondeu a uma planta ereta e a nota 5 a uma planta completamente acamada.

VAG - valor agronômico. Avaliado na maturidade atravēs de uma escala de notas visuais variando de 0 a 5 , onde a nota zero correspondeu a uma planta sem nenhum valor agronômico e a nota 5 a uma plan ta com excelentes caracteristicas agronômicas (grande nümero de vagens, sem sintomas de doenças, sem acamamento, ausência de hastes verdes, sem debulha de vagens).

PPI - produtividade de planta individual. Avaliada na maturidade através do peso dos grãos das plantas individuais amostradas (etiquetadas) na parcela. A unidade utilizada foi gramas por planta.

Após a colheita foi realizada uma complementação da secagem à sombra antes do beneficiamento. Todo o material, após o beneficiamento, foi exposto ao sol por dois dias e recolhido ao laboratório, esperando-se três dias para o início das pesagens. 


\subsection{Anālises Estatístico-Genēticas}

As anālises foram realizadas com base na média a nível de parcelas das observações feitas em plantas individuais para todos os caracteres. Os dados foram transformados para $\sqrt{x+1}$ nos seguintes caracte res: número de internódios no florescimento e na maturidade, acamamento e valor agronômico.

\subsubsection{Anālise de variância}

Duas anälises de variância foram realizadas, sendo uma em látice e outra em blocos completos casualizados.

O modelo linear utilizado para anālise em blocos casualizados (FREIRE FILHO, 1988; MIRANDA, 1987; TOLEDO \& KIIHL, 1982) foi:

$$
Y_{i j k}=\mu+T_{i j}+B_{k}+e_{i j k}
$$

onde:

$$
\begin{aligned}
\mathrm{Y}_{i j k}= & \text { observação realizada no ixj-ēsimo tratamento no k-ésimo } \\
& \text { bloco; } \\
\mu= & \text { média geral dos tratamentos; } \\
\mathrm{T}_{i j}= & \text { efeito do ixj-ésimo tratamento; } \\
B_{k}= & \text { efeito do k-ésimo bloco; } \\
e_{i j k}= & \text { efeito do erro experimental, que é normal e independente- } \\
& \text { mente distribuîdo com mëdia zero e variância } \sigma_{e}^{2} ; \\
i=j= & 1,2, \ldots, 10, \text { corresponde aos parentais; }
\end{aligned}
$$




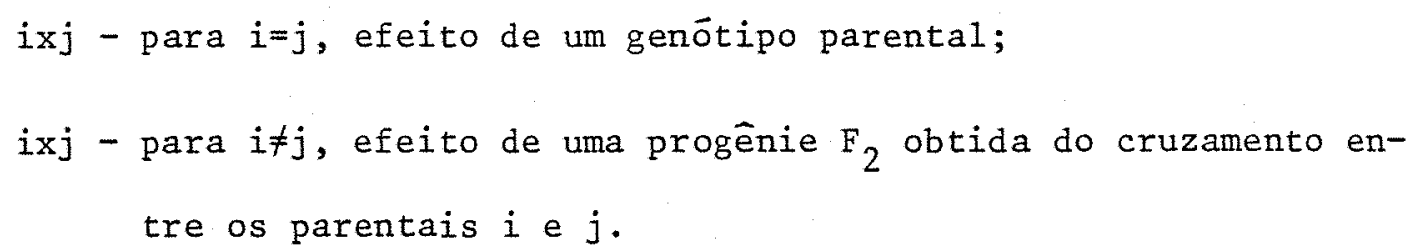

Na análise de blocos casualizados, fez-se a decomposição da soma de quadrados de grupos em parentais, progênies $\mathrm{F}_{2}$ e a respectiva comparação entre os grupos (parentais versus progênies $F_{2}$ ).

As comparações entre as mëdias dos tratamentos foram realizadas utilizando-se o teste de Tukey ao nível de probabilidade de 5\%.

\subsubsection{Anālise dialélica}

Para a anālise dialēlica utilizou-se o método 2 , modelo misto B, definido por GRIFFING (1956). O método 2 compreende os parentais e o conjunto dos $n(n-1) / 2$ hỉbridos (progênies $F_{2}$ ), sem incluir os reciprocos. Nesse modelo, os efeitos de tratamentos são fixos e os de blocos e erro experimental são aleatörios.

0 uso do modelo misto $B$ decorre da escolha deliberada dos parentais, os quais constituem a população a respeito da qual podem ser tiradas conclusões vālidas. Isso implica em que as possíveis inferências e conclusões limitam-se ao material experimental utilizado no presente estudo.

Sendo os efeitos de tratamentos fixos, os objetivos bási$\cos$ do estudo são a comparação das capacidades de combinação dos parentais quando os próprios são usados como testadores e a identificação das 
melhores combinações hỉbridas.

Para a anālise da capacidade de combinação considerou-se o mesmo modelo utilizado na análise de variância, desdobrando-se os efei tos de tratamentos em capacidade geral de combinação (CGC) e capacidade específica de combinação (CEC), de tal modo que:

$$
Y_{i j k}=\mu+g_{i}+g_{j}+s_{i j}+\frac{1}{b} \sum_{k=1}^{b} e_{i j k}
$$

onde:

$$
\begin{aligned}
\mu= & \text { média geral do dialelo; } \\
g_{i}= & \text { efeito da CGC do parental de ordem } i ; \\
g_{j}= & \text { efeito da CGC do parental de ordem } j ; \\
s_{i j}= & \text { efeito da CEC para o cruzamento entre os parentais de ordem } \\
& i \text { e de ordem } j . \text { Para os parentais } \\
& s_{i j}=s_{i i}=s_{j j} ; \\
& i, j=1,2,3, \ldots, n \\
& k=1,2,3, \ldots, b
\end{aligned}
$$

As seguintes restrições são impostas para que esse mode-

lo seja välido:

$e_{i j k}$ - deve apresentar distribuição normal e ser independentemente distribuído com mëdia zero e variância $\sigma_{e}^{2}$;

$$
\sum_{i=1}^{n} g_{i(j)}=0
$$


$\begin{aligned} \sum_{j} s_{i j}+s_{i i}= & 0 \quad(\text { para cada } i) . \\ & \text { Os efeitos da média, CGC e CEC foram estimados como se se- }\end{aligned}$ gue:

$$
\begin{aligned}
& \hat{\mu}=\frac{2}{n(n+1)} Y \ldots ; \\
& \hat{g}_{i}=\frac{1}{n+2}\left(Y_{i .}+Y_{i i}-\frac{2}{n} Y . .\right) ; \\
& \widehat{s}_{i j}=Y_{i j}-\frac{1}{n+2}\left(Y_{i .}+Y_{i i}+Y_{j}+Y_{j j}\right)+\frac{2}{(n+1)(n+2)} Y \ldots ;
\end{aligned}
$$

As variâncias das estimativas dos efeitos e das diferenças entre os efeitos foram estimadas da seguinte forma:

$$
\begin{aligned}
& \operatorname{Var}(\hat{\mu})=\frac{2}{n(n+1)} \hat{\sigma}^{2} ; \\
& \operatorname{Var}\left(\hat{g}_{i}\right)=\frac{n-1}{n(n+2)} \hat{\sigma}^{2} ; \\
& \operatorname{Varr}\left(\hat{s}_{i i}\right)=\frac{n(n-1)}{(n+1)(n+2)} \hat{\sigma}^{2} ; \\
& \operatorname{Var}\left(\hat{s}_{i j}\right)=\frac{n^{2}+n+2}{(n+1)(n+2)} \hat{\sigma}^{2} ; \text { com } i \neq j ; \\
& \operatorname{Varr}\left(\hat{g}_{i}-\hat{g}_{j}\right)=\frac{2}{n+2} \hat{\sigma}^{2}, \quad \text { com } i \neq j ;
\end{aligned}
$$


$\widehat{\operatorname{Var}}\left(\hat{s}_{i i}-\hat{s}_{i j}\right)=\frac{2(n-2)}{n+2} \hat{\sigma}^{2}$, com $i \neq j$

$\operatorname{Var}\left(\widehat{s}_{i j}-\widehat{s}_{i j}{ }^{\prime}\right)=\frac{2(n+1)}{n+2} \hat{\sigma}^{2}$, com $i \neq j$ e $j \neq j^{\prime}$;

$\operatorname{Var}\left(\hat{s}_{i j^{-}}-\hat{s}_{i j^{\prime}}\right)=\frac{2 n}{n+2} \hat{\sigma}^{2}$, com $i \neq j, i^{\prime}, j^{\prime} ;$

$j \neq i^{\prime}, j^{\prime}$ e $i^{\prime} \neq j^{\prime}$.

Além dessas variâncias para a média de qualquer parental ou progênie $F_{2}$, tem-se que:

$$
\hat{\operatorname{Var}}\left(\overline{\mathrm{Y}}_{i j}\right)=\hat{\sigma}^{2}=\mathrm{QMe}
$$

e que a variância da diferença entre duas mëdias quaisquer é

$$
\hat{\operatorname{Var}}\left(\overline{\mathrm{Y}}_{i j}-\overline{\mathrm{Y}}_{\mathrm{i}^{\prime} j^{\prime}}\right)=2 \hat{\sigma}^{2} ;
$$

sendo $\widehat{\sigma}^{2}=(\mathrm{QM}$ resíduo $) / b$.

Como salientado anteriormente, a obtenção de sementes $\mathrm{F}_{2}$ para o cruzamento EMGOPA-301 x IAC-5, não foi possivel. Os valores desse cruzamento para os värios caracteres foram estimados pela förmula (ECKHARDT, 1952):

$$
a \times b=\frac{(n-1)\left(T^{\prime} a+T^{\prime} b\right)-2 T^{\prime}}{n^{2}-5 n+6}
$$

onde:
$a \times b=$ estimativa do cruzamento para determinado caräter;
$\mathrm{n} \quad=$ nümero de parentais; 
T'a = somatōrio da Iinha "a" em uma tabela dialélica, excluindo o valor a x b;

$T^{\prime} b$ = somatōrio da linha "b" em uma tabela dialélica, excluindo o valor a $\times$ b;

linha "a" = cruzamentos que envolvem o parental "a";

linha "b" = cruzamentos que envolvem o parental "b";

$2 \mathrm{~T}^{\prime}$ = somatōrio geral da tabela dialélica menos $2 \mathrm{ab}$;

a fórmula utilizada não inclui os parentais na estimativa do cruzamento.

\subsection{Heterose e Heterobeltiose}

Devido à utilização de progênies $F_{2}$, os resultados foram multiplicados por dois para que os mesmos fossem expressos ao nivel de $F_{1}$. As estimativas foram obtidas da seguinte forma:

$$
\begin{aligned}
& \text { Heterose }=\frac{2\left(\overline{\mathrm{F}}_{2}-\overline{\mathrm{MP}}\right)}{\overline{\mathrm{MP}}} \cdot 100 ; \\
& \text { Heterobeltiose }=\frac{2\left(\overline{\mathrm{F}}_{2}-\overline{\mathrm{PS}}\right)}{\overline{\mathrm{PS}}} \cdot 100 ;
\end{aligned}
$$

sendo:

$$
\begin{aligned}
& \overline{\mathrm{F}}_{2}=\text { média da progênie } \mathrm{F}_{2} ; \\
& \overline{\mathrm{MP}}=\frac{\overline{\mathrm{P}}_{i}+\overline{\mathrm{P}}_{j}}{2} \text {, média dos parentais da progênie } \mathrm{F}_{2(i j)} ; \\
& \overline{\mathrm{PS}}=\text { média do respectivo parental superior. }
\end{aligned}
$$


As significâncias das estimativas foram testadas aos niveis de probabilidade de 5 e $1 \%$ pelo teste " $t$ ", para os contrastes $2\left(\overline{\mathrm{F}}_{2}-\overline{\mathrm{MP}}\right)$ e $2\left(\overline{\mathrm{F}}_{2}-\overline{\mathrm{PS}}\right)$, conforme procedimento adotado por PIMENTEL GOMES $(1985)$.

\subsection{Comparação dos tipos de parcelas experimentais}

Nesta pesquisa, foram utilizados três tipos de parcelas des critos em 3.1.3: covas (experimento 1), fileiras de 1 metro de comprimen to (experimento 2) e fileiras de 3 metros (experimento 3). 0 grau de concordância entre os resultados obtidos nos três tipos de parcelas foi avaliado através do coeficiente de correlação linear simples, combinandose dois a dois os três tipos de parcelas.

Foram estimadas três correlações a partir das médias de tratamentos de cada caräter, envolvendo: 39 pares de médias ( 9 parentais e 30 progênies $F_{2}$ ) na correlação entre covas e fileiras de $1 \mathrm{~m} ; 19$ pares de médias ( 9 parentais e 10 progênies $F_{2}$ ) tanto na correlação entre covas e fileiras de $3 \mathrm{~m}$ quanto na correlação entre fileiras de $1 \mathrm{~m}$ e fileiras de 3m. Desta maneira, foram estimadas 27 correlações ( 3 tipos de parcelas $x$ 9. caracteres) para cada grupo de tratamentos: parentais, progênies $F_{2}$ e (parentais + progênies $\mathrm{F}_{2}$ ). No total, foram estimadas 81 correlações.

A significância dos coeficientes de correlação fenotípica foi verificada pelo teste " $t$ ", com $n-2$ graus de liberdade, aos niveis de 5 e $1 \%$ de probabilidade, segundo procedimento adotado por PIMENTEL GOMES (1985). 


\section{RESULTADOS E DISCUSSÃO}

\subsection{Anälise de Variância}

Os valores e respectivas significâncias dos quadrados médios das anālises de variância em blocos casualizados para os caracteres número de dias para o início do florescimento (NDF), nümero de internōdios no florescimento (NIF), altura da planta no florescimento (APF), nümero de dias para a maturidade (NDM), nümero de internödios na maturidade (NIM), altura da planta na maturidade (APM), acamamento (ACM), valor agronômico (VAG) e produtividade de planta individual (PPI) são apresentados na Tabela 2. Para todos os caracteres são apresentados tambēm os respectivos coeficientes de variação experimental.

Verificou-se através dos coeficientes de variação que a precisão das anālises apresentou níveis bastante satisfatörios. Para cinco caracteres foram inferiores a $5 \%$, para outros três foram aproximadamente de $10 \%$ e somente para o caráter PPI ficou ao redor de $20 \%$.

Os quadrados médios para tratamentos (grupos) e os desdobramentos em parentais, progênies $F_{2}$ e $P$ Vs $F_{2}$, foram significativos ao 
nivel de $1 \%$ pelo teste "F", para todos os caracteres avaliados, exceto para NDF e ACM, nos quais não houve diferença significativa para $P$ vs $F_{2}$. A significância dos quadrados médios dos parentais e das progênies $F_{2}$ mostra que há uma grande variabilidade nesse conjunto de parentais, evidenciando a possibilidade de formação de uma população de base genética bastante ampla a partir desse material. A significância da comparação entre os grupos, feita através da fonte de variação parentais versus progênies $F_{2}$ ( $P$ vs $F_{2}$ ), indica a presença de heterose nos hỉbridos.

4.2. Avaliação dos parentais, progênies $\mathrm{F}_{2}$, heterose e heterobeltiose

\subsubsection{Caracteres relacionados ao florescimento}

A média, variância e as porcentagens de heterose e heterobeltiose, para os caracteres $\mathrm{NDF}$, NIF e APF, e as respectivas diferenças mínimas significativas (DMS) ao nível de $5 \%$ pelo teste de Tukey para comparações entre parentais e entre progênies $F_{2}$, são apresentados na Tabela 3 .

Para o caräter NDF os parentais apresentaram média de 53 dias e variância de 3 (dias) $^{2}$, enquanto as progênies $F_{2}$ floresceram em 52 dias em média com variância de 14 (dias) $^{2}$. Mesmo tratando-se de um grupo de cultivares semi-tardios, diferenças significativas (5\%) para NDF foram observadas. Entre os parentais, a amplitude de variação foi de 47 dias (Santa Rosa e IAC-4) a 59 dias $(I A C-6)$; os demais parentais tiveram tempo para florescimento dentro do intervalo anterior. Os parentais Cristalina, 
IAC-6, IAC-8 e IAC-9 apresentaram variâncias relativamente altas para esse caräter; isto sugere que esses parentais podem não estar totalmente homozigotos para NDF.

$$
\text { Observa-se que entre as progênies } F_{2} \text {, O NDF variou de } 46
$$
dias no cruzamento IAC-4 x IAC-5 a 59 dias no cruzamento EMGOPA-301 x IAC8, muito semelhante ao intervalo observado nos parentais. Os cruzamentos mais tardios foram EMGOPA-301 x IAC-8 (59,0 dias), IAC-6 x SS-1 (57,6 dias), IAC-6 6 IAC-9 (57,3 dias), IAC-6 $\times$ IAC-11 (57,0 dias) e EMGOPA-301 $x$ IAC-6 (56,0 dias). As respectivas variâncias foram de 8,$07 ; 2,31 ; 4,40$; 8,20 e 6,46 (dias) $^{2}$. Percebe-se que esses parentais apresentam um grande potencial para retardar o florescimento mesmo em cultivo de inverno.

A heterose foi predominantemente negativa para NDF; dos 44 cruzamentos, 29 apresentaram heterose negativa e 15 foram positivas. Os valores com heterose positiva mais expressivos foram detectados nos cruzamentos EMGOPA-301 x IAC-8 $(19,4 \%)$, IAC-5 x Santa Rosa $(3,9 \%)$, IAC-6 $\times$ IAC-11 (3,6\%) e Cristalina $x \operatorname{IAC}-11(3,6 \%)$. A heterobeltiose foi calcala da com relação ao parental mais precoce e ao parental mais tardio. Para a maioria dos cruzamentos, a progênie $F_{2}$ foi mais tardia que o parental mais precoce, apresentando diferenças significativas em 27 cruzamentos. Considerando-se a heterobeltiose em relação ao parental mais tardio, cinco cruzamentos mostraram estimativas positivas; entretanto, somente o cru zamento EMGOPA-301 x IAC-8 $(16,64 * *)$ apresentou significância. As demais progênies $F_{2}$ apresentaram estimativas negativas em relação ao parental mais tardio, evidenciando uma tendência das progênies $F_{2}$ terem tempo para florescimento intermediärio em relação aos respectivos parentais. Através 
das estimativas da média e da variância para esse caräter, verifica-se a possibilidade de serem obtidos materiais mais tardios que os integrantes deste grupo de parentais; por exemplo, o cruzamento EMGOPA-301 x IAC-8 apresentou média de 59 dias e variância de 8 (dias) ${ }^{2}$.

VEATCH (1930) constatou maior freqüência de cruzamentos apresentando heterose e heterobeltiose positivas, resultado que difere do observado neste estudo. Entretanto, CAMPOS (1979) e CHAUDHARY \& SINGH (1974) obtiveram estimativas predominantemente negativas. FREIRE FILHO (1988) observou em 45 cruzamentos, 32 com heterose negativa, das quais sete foram significativas; quanto à heterobeltiose, detectou 17 cruzamen tos com diferenças significativas em relação ao parental mais precoce e 25 cruzamentos com relação ao parental mais tardio. Os resultados obtidos confirmaram a dominância do florescimento precoce, estando de acordo com os demais autores, exceto com os resultados observados sob condições de dias longos por VEATCH (1930).

A média do NIF variou de 10,4 no parental IAC-4 a 13,8 no parental IAC-6, o qual diferiu significativamente dos outros parentais. A variāncia dos parentais Cristalina e IAC-4 foram relativamente altas com relação aos demais, sugerindo que os mesmos poderão não estar totalmente em homozigose para o NIF. Nas progênies $F_{2}$, $\circ$ NIF variou de 10,3 no cruzamento IAC- 8 x Santa Rosa a 14,4 no cruzamento Cristalina x IAC-6. Os cruzamentos com maiores valores para NIF foram Cristalina $x$ IAC-6 $(14,4)$, Cristalina $x$ EMGOPA-301 $(14,1)$, IAC-6 x IAC-9 $(14,0)$, IAC-6 $x$ IAC-11 $(13,8)$ e Cristalina X IAC-11 $(13,5)$. Os dados mostram que os parentais Cristalina, IAC-6 e IAC-11, apresentaram grande potencial para 
elevar o NIF. As variāncias observadas variaram de 1,2 no cruzamento EMGOPA-301 x IAC-9 a 7,6 no cruzamento Santa Rosa x SS-1. Os maiores valores foram observados nos cruzamentos Santa Rosa x SS-1 $(7,6)$, IAC-8 $x$ SS-1 $(6,3)$, Cristalina $\times$ SS-1 $(6,0)$, IAC-9 $\times$ SS-1 $(5,3)$ e IAC-5 x SS-1 $(4,9)$. Verifica-se que o parental SS-1 participou dos cruzamentos com maior variância para NIF; isto indica que este genótipo pode contribuir com o aumento do NIF através de seleção.

A heterose foi predominantemente positiva, sendo significativa para 36 cruzamentos. A variação foi de $-21,5$ no cruzamento IAC-4 x IAC-6 a 31,4 no cruzamento Cristalina $x$ EMGOPA-301. Os dados sugerem uma tendência das progênies $F_{2}$ apresentarem NIF superior à mëdia dos parentais.

A heterobeltiose variou de $-43,4$ no cruzamento IAC $-4 \mathrm{x}$ IAC-6 a 20,4 no cruzamento Cristalina $x$ EMGOPA-301. Para NIF, 50\% das progênies $\mathrm{F}_{2}$ apresentaram valores positivos, sendo 21 significativos. Isso indica que $50 \%$ das progênies $\mathrm{F}_{2}$ situaram-se entre a média dos parentais e o respectivo parental superior; a outra metade apresentou média superior ao respectivo parental superior. Nas progênies $F_{2}$ com heterobeltiose positiva e significativa, evidenciou-se a ocorrência de sobredomināncia para o carāter NIF.

o nümero de nós na haste principal, que se mostra como medida semelhante ao NIF, apresentou heterose predominantemente positiva VEATCH (1930) e CAMPOS (1979). O caráter NIF foi avaliado por FREIRE FILHo (1988) em genótipos precoces de soja, sendo obtidos resultados similares aos detectados neste estudo para heterose. Para a heterobeltiose, 
VEATCH (1930) observou maior frequência de valores positivos; por outro lado, CAMPOS (1979) e FREIRE FILHO (1988) obtiveram valores predominantemente negativos. Entretanto, os resultados obtidos nesse estudo aproxi mam-se dos obtidos por CHAUDHARY \& SINGH (1974), onde a comparação com o parental superior apresentou metade dos cruzamentos com valores positivos.

Os parentais apresentaram em média $38,7 \mathrm{~cm}$ de $A P F$, enquanto as progênies $\mathrm{F}_{2}$ foram levemente superiores, com média de $40,7 \mathrm{~cm}$. A APF nos parentais variou de $28,8 \mathrm{~cm}$ no parental $1 A C-4$ a $46,5 \mathrm{~cm}$ no parental IAC-6. Os parentais EMGOPA-301 e IAC-6, obtiveram as maiores variâncias, respectivamente 74,0 e 53,6 , sendo inclusive superiores às variâncias de alguns cruzamentos. Entre as progênies $F_{2}$, a variação foi de $31,2 \mathrm{~cm}$ no cruzamento IAC-4 x Santa Rosa a $54,5 \mathrm{~cm}$ no cruzamento Cristalina $\mathrm{x}$ EMGOPA301. As variâncias dos cruzamentos foram relativamente altas; isto refletiu a ampla variabilidade existente para APF.

A heterose para APF foi predominantemente positiva, sendo significativa em 22 cruzamentos. Os cruzamentos com valores mais expressivos foram Cristalina x EMGOPA-301 $(83,2)$, Cristalina x IAC- $8(34,5)$, IAC-4 x IAC-5 $(29,2)$, Cristalina $\times$ IAC-6 $(28,6)$ e EMGOPA-301 x Santa Rosa $(28,1)$. Esses resultados indicaram que as progênies $F_{2}$ tenderam a apresentar APF superior à média dos parentais.

A heterobeltiose apresentou valores negativos para a maioria dos cruzamentos; entretanto, para 19 cruzamentos obtiveram-se estimativas positivas, das quais cinco foram significativas: Cristalina x EMGOPA-301 $(67,0)$, EMGOPA-301 $\times \operatorname{IAC}-9(21,7)$, EMGOPA-301 x SS-1 $(21,4)$, EMGOPA-301 $\times$ 
IAC-11 (17,0) e Cristalina x SS-1 $(14,8)$. Os parentais Cristalina, EMGOPA-301 e SS-1 mostraram-se com grande potencial para elevar a APF, o que $\bar{e}$ altamente desejävel.

As estimativas de heterose e heterobeltiose indicaram que as progênies $\mathrm{F}_{2}$ tenderam a se colocar entre a média dos parentais e o parental superior. FREIRE FILHO (1988) obteve na média de 15 cruzamentos, valor positivo para heterose e negativo para heterobeltiose, respectiva mente 5,9 e $-12,0 \%$. Esses resultados, em média, estão de acordo com os obtidos neste estudo, evidenciando a ocorrência de dominância parcial para maior altura no florescimento.

\subsubsection{Caracteres relacionados à maturidade}

A média, variância e as porcentagens de heterose e heterobeltiose, para os caracteres NDM, NIM e APM, e as respectivas diferenças minimas significativas ao nível de $5 \%$ pelo teste de Tukey para comparação entre parentais e entre progênies $F_{2}$, são apresentados na Tabela 4.

Os parentais apresentaram diferenças significativas para NDM, alcançando em média a maturidade com $125,1 \pm 8,6$ dias. Os parentais IAC-4 e Santa Rosa foram os mais precoces $(112,9$ dias) e os mais tardios foram Cristalina ( 136,7 dias) e IAC-6 ( 132,4 dias), fato que implicou numa diferença em torno de 24 dias para atingir a maturidade. Essa ampli tude é de considerável importância prática, visto que o plantio foi realizado em janeiro. Os parentais Cristalina e IAC-6 foram também os que apresentaram florescimento mais tardio; isto indicou a existência de genes para período juvenil nos mesmos. 
As progênies $F_{2}$ foram, em média, mais precoces que os parentais, atingindo a maturidade com $122,9 \pm 6,1$ dias. Foram detectadas diferenças significativas para os cruzamentos, sendo o mais precoce, o cruzamento IAC-4 x Santa Rosa $(111,9$ dias) e o mais tardio Cristalina $\mathrm{x}$ IAC-9 (134,6 dias). Verificou-se que tal variação foi praticamente a mes ma observada para os parentais e que os dois cruzamentos envolveram os parentais mais precoces (IAC-4 e Santa Rosa) e o mais tardio (Cristalina), respectivamente, em termos de maturidade. As variâncias dentro de progênies $F_{2}$ foram relativamente altas, variando de 1,9 (IAC-6 x SS-1) a 192,8 dias $^{2}$ (IAC-11 x SS-1); a variância média dentro de progênies $\mathrm{F}_{2}$ foi $42,1 \pm 42,2$ dias $^{2}$. Todos os cruzamentos que apresentaram variância acima de 42 (dias) $^{2}$ ofereceriam oportunidade para a prätica de seleção visando-se genótipos com maturidade mais precoce e com periodo juvenil.

A heterose foi negativa na maioria dos cruzamentos, apresentando média de $-3,5 \pm 4,3 \%$, indicando que as progênies $F_{2}$ situaramse em torno da média dos parentais com uma tendência de dominância parcial para maturidade precoce.

A heterobeltiose com relação ao parental mais precoce apre sentou média de 4,9 $\pm 6,3 \%$. Em 34 cruzamentos, a heterobeltiose foi positiva, dos quais 13 apresentaram diferenças significativas, sendo portan to, mais tardios em relação ao parental mais precoce. Entretanto, a heterobeltiose com relação ao parental mais tardio foi predominantemente negativa, observando-se somente uma estimativa positiva, porém não significativa; a média foi de $-11,0 \pm 7,5 \%$, indicando que as progênies $F_{2}$ tenderam a ser mais precoces que os respectivos parentais mais tardios. 
Esses resultados estão de acordo com os obtidos por FREIRE FILHO (1988) que obteve médias negativas para heterose e heterobeltiose com relação ao parental mais tardio e média positiva em relação ao parental mais precoce. Tambēm foram similares às estimativas de CAMPOS (1979) e KAW \& MENON (1979) que obtiveram médias negativas tanto para heterose quanto para heterobeltiose, considerando-se o parental mais tardio. WEBER et alii (1970) em um período de quatro anos, obtiveram heterose média positiva em três anos e negativa em apenas um ano; entretanto, a média do NIM nos parentais foi de $14,8 \pm 1,5$ internódios, enquanto as progênies $F_{2}$ apresentaram 15,2 $\pm 1,4$; praticamente, não existiu diferenças para NIM, em termos médios. Contudo, os parentais e as progēnies $F_{2}$ apresentaram diferenças significativas dentro de cada grupo. O NIM variou de 12,2 no parental IAC-4 a 16,9 no parental IAC-5, o qual diferiu significativamente dos outros parentais. Esses parentais foram os que apresentaram tambëm menor e maior APM, respectivamente 36,5 e $63,4 \mathrm{~cm}$. Nota-se que omaior valor para NIM ocorreu no parental IAC-5, sendo que o mesmo è o único de crescimento indeterminado. A variância média entre os parentais foi de $2,9 \pm 0,9$ (internōdios) ${ }^{2}$.

Nas progênies $F_{2} \circ$ NIM variou de 12,4 no cruzamento EMGOPA$301 \times$ IAC-4 a 18,7 no cruzamento IAC-5 x IAC-11, variação esta que superou o valor do parental com maior NIM. Verificou-se que os parentais IAC-4 e IAC-5, respectivamente os que apresentaram menor e maior NIM, participaram das progênies $F_{2}$ contribuindo na mesma direção. As progênies $\mathrm{F}_{2}$ apresentaram variância média de $5,2 \pm 3,5$ (internódios) $^{2}$ e variaram de 1,9 no cruzamento IAC-6 x IAC-11 a 18,2 no cruzamento IAC-5 x IAC-9. 
Isto indicou a existência de variabilidade para seleção quanto ao NIM.

A heterose apresentou média de $5,6 \pm 10,3 \%$ para NIM, variando de $-12,8$ no cruzamento IAC-4 x SS-1 a 30,6 no cruzamento IAC-5 $x$ IAC-11. O valor mais expressivo para heterose foi observado no cruzamento que apresentou maior NIM. As estimativas foram predominantemente positivas, sendo que 31 cruzamentos apresentaram diferenças significativas. Os resultados evidenciaram tendência de dominância para maior NIM.

A heterobeltiose foi negativa para a maioria dos cruzamentos; entretanto, 17 cruzamentos apresentaram valores positivos, sendo 15 significativos. A média foi de $-5,4 \pm 12,2 \%$ com variação de $-34,0$ no cru zamento IAC-4 x SS-1 a 21,6 no cruzamento IAC-5 x IAC-11. Esses resultados de um modo geral, indicaram que as progênies $F_{2}$ situaram-se entre a média dos parentais e o parental superior; entretanto, em vârios cruzamentos as progênies superaram a média do parental com maior NIM. A partir deste fato, visualizou-se a possibilidade de sucesso na seleção de progênies com NIM maior que os parentais.

A utilização de covas individuais poderia ter influenciado a expressão do vigor de hỉbrido, devido ao espaçamento mais largo entre plantas dentro de fileiras. Entretanto, tal fato não ocorreu, pois os resultados obtidos nesse estudo estão de acordo com CAMPoS (1979) e KAW \& MENON (1979) para o caräter nümero de nös. Assim como são concordantes com as estimativas obtidas por FREIRE FILHO (1988) para NIM, embora esse autor tenha utilizado parcelas constituídas por fileiras de. $5 \mathrm{~m}$ de comprimento. 
Os parentais apresentaram APM média de $51,6 \pm 8,5 \mathrm{~cm}$ varian do de $36,5 \mathrm{~cm}$ no parental IAC-4 a $63,4 \mathrm{~cm}$ no parental IAC-5. A média das variâncias nos parentais foi de $48,4 \pm 22,5(\mathrm{~cm})^{2}$, sendo que quatro parentais apresentaram valores maiores que a variância média: EMGOPA-301 $\left(91,9 \mathrm{~cm}^{2}\right), \operatorname{IAC}-8\left(72,5 \mathrm{~cm}^{2}\right), \operatorname{IAC}-6\left(62,2 \mathrm{~cm}^{2}\right)$ e IAC-9 $\left(57,7 \mathrm{~cm}^{2}\right)$. Esses valores sugerem que os mesmos podem ter sido influenciados pelo ambiente, ou então não estarem totalmente homozigóticos para os genes que contro$\operatorname{lam}$ a APM.

As progênies $F_{2}$ apresentaram média superior aos parentais, atingindo $54,9 \pm 8,3 \mathrm{~cm}$ na maturidade. A altura das progênies variou de $37,5 \mathrm{~cm}$ no cruzamento $\mathrm{IAC}-4 \mathrm{x}$ Santa Rosa a $71,1 \mathrm{~cm}$ no cruzamento IAC-5 $\mathrm{x}$ IAC-11. Observou-se que nos valores extremos os parentais IAC-4 e IAC-5, os quais apresentaram respectivamente, menores e maiores estimativas para NIM e APM, mantiveram a mesma tendência nas suas progênies. A média das variâncias dentro de progennies foi de $118,6 \pm 83,9(\mathrm{~cm})^{2}$, sendo detectados valores relativamente altos em värios cruzamentos, cuja variação foi de 39,8 no cruzamento IAC-6 $\times$ IAC-11 a 384,0 no cruzamento IAC-5 $x$ SS-1. Verificou-se, através desses resultados, a existência de variabilidade suficiente na APM para prática de seleção.

A heterose foi predominantemente positiva, apresentando significância em 26 cruzamentos. A média das estimativas foi de $12,9 \pm$ $18,0 \%$, variando de $-24,0$ no cruzamento IAC-4 x SS-1 a 72,8 no cruzamento Cristalina x EMGOPA-301. Vale salientar que em todos os cruzamentos em que o parental IAC-5 participou, a heterose foi positiva e significativa, evidenciando que neste caso a média da progênie $F_{2}$ foi sempre superior à 
média dos parentais. Estimativas positivas para heterose tem sido relatadas por diversos autores (CHAUDHARY \& SINGH, 1974; CHAUHAN \& SINGH, 1982; FREIRE FILHO, 1988; KUNTA et alii, 1985; VEATCH, 1930; WEBER et alii, 1970; WENTZ \& STEWART, 1924). Atravēs da literatura consultada ape nas o trabalho de KAW \& MENON (1979) diferiu dos resultados obtidos nesse estudo, sendo detectada heterose média negativa para a APM. Entretanto, com base na revisão efetuada, percebe-se maior freqüencia de heterose positiva para APM.

A heterobeltiose para APM apresentou estimativas negativas na maioria dos cruzamentos, porém, estimativas positivas foram observadas em 20 cruzamentos, sendo dez significativas. A média foi de $-5,4 \pm 22,3 \%$ e variou de $-56,3$ no cruzamento IAC-4 x SS-1 a 59,4 no cruzamento Cristalina x EMGOPA-301. PASCHAL II \& WILCOX (1975) relataram que as progênies $\mathrm{F}_{1}$ tenderam a ser intermediärias em relação aos parentais. A mesma tendência foi observada por FREIRE FILHO (1988) utilizando progênies $\mathrm{F}_{2}$ para obtenção das estimativas, salientando ainda que, as progênies $\mathrm{F}_{2}$ tenderam a situar-se entre a média dos parentais e o parental superior. A mesma tendência foi observada nesse estudo; entretanto, em alguns cruzamentos; verificou-se que as progênies $F_{2}$ mostraram-se superiores ao parental com maior APM.

As estimativas para heterobeltiose média são contrastantes na literatura, existindo estimativas negativas (CAMPOS, 1979; FREIRE FILHO, 1988; WEBER et alii, 1970), como tambëm heterobeltioses médias positivas (CHAUDHARY \& SINGH, 1974; KUNTA et alii, 1985; VEATCH, 1930). As progênies que excederam o parental superior nesse estudo, podem ter 
sido influenciadas pela utilização de covas individuais, no sentido de favorecer a expressão do vigor de hỉbrido.

\subsubsection{Acamamento, valor agronômico e produtividade}

Na Tabela 5 são apresentados os dados referentes à média, variância e as porcentagens de heterose e heterobeltiose para os caracteres $A C M, V A G$ e PPI, e as respectivas diferenças minimas significativas (DMS) ao nível de $5 \%$ pelo teste de Tukey para comparações entre parentais e entre progênies $F_{2}$.

Os caracteres ACM e VAG foram avaliados através de uma escala de notas visuais e as análises de dados foram processadas com transformação dos mesmos para $\sqrt{x+1}$.

o melhor comportamento para o carāter ACM, correspondeu as menores notas da escala. A média dos parentais foi de $1,7 \pm 0,5$ e variou de 1,1 no parental IAC-4 a 2,5 no parental IAC-6. A média das variâncias dos parentais foi de $1,5 \pm 1,0$ com valores compreendidos entre 0,1 a 3,6 nos parentais IAC-4 e EMGOPA-301, respectivamente.

O ACM nas progênies $\mathrm{F}_{2}$ foi praticamente igual ao observado nos parentais, com média de $1,8 \pm 0,4$ e variou de 1,1 nos cruzamentos IAC-4 x Santa Rosa e IAC-8 x Santa Rosa a 2,9 no cruzamento IAC-5 x IAC-8. A variância média das progênies $F_{2}$ foi de $1,6 \pm 0,7$, sendo o maior valor obtido no cruzamento Cristalina x EMGOPA-301 $(2,7)$.

As estimativas da heterose foram positivas para a maioria dos cruzamentos, com média de $14,3 \pm 38,9$. A variação observada foi de 
$-62,6$ no cruzamento IAC-8 x Santa Rosa a 86,2 no cruzamento IAC-6 x SS-1. Esses resultados mostraram que as progênies $F_{2}$ tenderam a apresentar grau de ACM levemente superior em relação a média dos parentais. Os dados obtidos por FREIRE FILHO (1988) são um pouco discordantes deste trabalho; - autor obteve estimativas de heterose negativas para a maioria dos cruzamentos e constatou média também negativa $(-11,3 \pm 24,6 \%)$. As condições de competição foram diferentes; FREIRE FILHO (1988) utilizou plantas competitivas ( $10 \mathrm{~cm}$ entre plantas dentro de fileiras), enquanto que, neste estudo as estimativas obtidas basearam-se em plantas sem competição.

As heterobeltioses estimadas foram positivas para a maioria dos cruzamentos, quando comparadas com o parental superior, neste caso 0 que apresentou menor escore. A heterobeltiose média foi de $57,1 \pm 54,8 \%$ e apresentou significância para a maioria dos cruzamentos. Para esse caräter, seria interessante que a heterobeltiose fosse negativa, assim as progênies $\mathrm{F}_{2}$ apresentariam maior resistência ao $\mathrm{ACM}$ em relação ao parental mais resistente. Quanto às estimativas da heterobeltiose, os resultados desse estudo estão de acordo com FREIRE FILHo (1988), o qual detectou média de $25,0 \pm 30,0 \%$ e estimativas positivas para a maioria dos cruzamentos. Contudo, as progênies $F_{2}$ exibiram variabilidade adequada pa ra a prática de seleção visando a maior resistência ao ACM.

Os parentais apresentaram mëdia de $2,9 \pm 0,5$ para VAG, havendo diferenças significativas entre os mesmos, que variaram de 1,9 no parental IAC-4 a 3,4 no parental IAC-6. As variancias foram relativamente uniformes, com média de $0,24 \pm 0,1$, variando de 0,2 a 0,4 nos parentais EMGOPA-301 e IAC-6, respectivamente. 
As progēnies $\mathrm{F}_{2}$ tambēm apresentaram diferenças significativas para VAG, com média de $3,0 \pm 0,4$ e variação de 2,1 no cruzamento IAC-4 x Santa Rosa a 3,7 no cruzamento Cristalina x EMGOPA-301. Vale observar que o cruzamento IAC-4 x Santa Rosa foi o mais precoce e também. o que apresentou menor altura na maturidade, enquanto que o cruzamento Cris talina x EMGOPA-301, apresentou a maior altura no florescimento e a maior estimativa de heterose para APM. A média das variâncias foi de $0,4 \pm 0,2$ e variou de 0,1 no cruzamento IAC-6 $\times$ IAC-11 a aproximadamente 1,0 no cru zamento IAC-5 x SS-1. Os resultados obtidos indicaram a existência de variabilidade considerävel para o VAG.

As estimativas de heterose foram predominantemente positivas, das quais 31 mostraram-se significativas. A média foi de $8,2 \pm 16,8 \%$, variando de $-28,9$ no cruzamento IAC-6 x Santa Rosa a 51,7 no cruzamento IAC-4 x IAC-5. Aproximadamente metade das estimativas para heterobeltiose foram positivas, apresentando média de $-7,6 \pm 24,8 \%$. Entre as estimativas positivas apenas uma não foi significativa, indicando que o VAG das progênies mostrou-se superior à mẻdia dos parentais e em muitos cruzamentos foi maior que o respectivo parental superior. Os resultados obtidos sugerem apreciāvel variabilidade para esse caräter.

A avaliação de uma planta ou progēnie, através do VAG, reflete a utilização de um Indice mental que engloba um conjunto de vārios caracteres agronômicos simultaneamente, sendo expresso através de uma nota. Como ressaltou FREIRE FILHO (1988), o VAG empregado para avaliar progênies $F_{2}$, não apresenta uma boa eficiencia para fins de seleção. Devido à considerâvel ação da heterose nessa geração, a avaliação visual 
poderā refletir, pelo menos em parte, o vigor de híbrido, o qual não se mantēm através do processo de avanço de gerações em direção à homozigoze. BRIM (1973) relatou que esquemas de seleção visual têm sido utilizados visando reduzir o nümero de progênies para um nível tal, que viabilize a avaliação do potencial produtivo, enfatizando ainda, que tais esquemas são efetivos para caracteres de alta herdabilidade.

A avaliação da produtividade foi realizada atravēs do peso de grãos em plantas individuais (PPI) amostradas nas parcelas. o conjunto dos parentais apresentou diferenças significativas ao nível de probabilidade de $1 \%$. A média dos parentais foi de $68,4 \pm 14,9 \mathrm{~g} / \mathrm{p} 1$ anta e variou de 43,2 no parental Santa Rosa a $88,1 \mathrm{~g} / \mathrm{planta}$ no parental sS- 1 . As variāncias dos parentais tiveram média de $780,8 \pm 327,1$ (g/planta) ${ }^{2}$. Os valores mais expressivos foram apresentados pelos parentais Cristalina, EMGOPA-301, IAC-6 e IAC-9, respectivamente $1223,902,1420$ e 880 (g/planta) ${ }^{2}$.

A PPI mëdia das progênies $F_{2}$ foi de $78,6 \pm 17,1 \mathrm{~g} / \mathrm{planta}$, superando em média $10 \mathrm{~g} / \mathrm{planta}$ o conjunto dos parentais. A produtividade variou de 44,1 no cruzamento IAC-4 x Santa Rosa a 108,9 g/planta no cruzamento Cristalina $\times$ IAC-6. Entre as progênies $F_{2}, 29$ apresentaram média superior ao conjunto dos parentais, sendo que 16 superaram o parental mais produtivo. A média das variâncias foi de $1369,5 \pm 666,0$ (g/planta) ${ }^{2}$ e variou de 331,4 no cruzamento IAC-4 x Santa Rosa a 3249,0 (g/planta) ${ }^{2}$ no cruzamento IAC-5 x SS-1.

A maioria das estimativas de heterose foram positivas e 16 apresentaram diferenças significativas. A média foi de $28,1 \pm 31,0 \%$ e 
variou de $-38,3$ no cruzamento IAC-4 x IAC-6 a 94,8 no cruzamento Cristalina $\times$ EMGOPA-301. O cruzamento Cristalina x EMGOPA-301 apresentou a maior APF, a heterose mais pronunciada para APM e foi o segundo mais produtivo entre as progênies $\mathrm{F}_{2}$, com mëdia de $107,0 \mathrm{~g} / \mathrm{planta.} \mathrm{Esses} \mathrm{resul-}$ tados indicaram que o cruzamento Cristalina x EMGOPA-301 mostrou ótimo desempenho, evidenciando a possibilidade de obtenção de combinações superiores para o cultivo de inverno.

As estimativas de heterobeltiose foram predominantemente positivas com média de $2,5 \pm 34,7 \%$. Entre os 25 cruzamentos que apresentaram heterobeltiose positiva, apenas quatro foram significativas ao nivel de $5 \%$ de probabilidade: Cristalina x EMGOPA-301 $(48,0)$, Cristalina $\mathrm{x}$ IAC-6 $(52,3) ; \operatorname{EMGOPA-301} \times \operatorname{IAC}-8(43,9)$ e $\operatorname{IAC}-8 \times \operatorname{IAC}-9(49,2)$. A heterobeltiose variou de $-62,3$ no cruzamento IAC-4 4 IAC-6 a 52,3 no cruzamento Cristalina $\mathrm{x}$ IAC-6. Esses resultados mostraram que a maioria das progênies $F_{2}$ foi superior à média dos parentais, sendo que algumas progênies superaram a média do respectivo parental superior. Observou-se através das médias e das estimativas de variância das progênies $F_{2}$, que hâ considerāvel variabilidade para o carāter PPI.

A heterose média obtida nesse estudo está de acordo com tó dos os resultados na literatura consultada, geralmente avaliando a produtividade em gramas/planta e constatando estimativas positivas. A média obtida por CAMPOS (1979) foi de 19,0\%; CHAUHAN \& SINGH (1982), 48,4\%; FREIRE FILHO (1988), 5,2\%; KAW \& MENON (1979), 17,4\%; KUNTA et alii (1985), 24,6\%; VEATCH (1930), 35,5\%; WEBER et alii (1970), 25,1\% e WEISS et alii $(1947), 20,8 \%$. 
A mesma tendência foi observada para heterobeltiose, onde as estimativas na literatura foram predominantemente positivas, estando de acordo com o resultado desse estudo. A média obtida por CAMPOS (1979) foi de $3,3 \%$; CHAUDHARY \& SINGH (1974), 26,1\%; KAW \& MENON (1979), 4,3\%; KUNTA et alii (1985); 20,1\%; PASCHAL II \& WILCOX (1975), 8,0\%; VEATCH (1930), 19,6\%; WEBER et alii (1970), 13,4\% e WEISS et alii (1947), 14,5\%. A ünica estimativa negativa para heterobeltiose média na literatura consultada, foi obtida por FREIRE FILHO (1988), com média de -22,2\%. Entretanto, o autor ressaltou que duas progênies $F_{2}$ superaram o melhor parental do grupo no carāter PPI.

Para que haja exploração comercial de hïbridos em soja, dois requisitos devem ser satisfeitos: a) um método econômico para produção de sementes híbridas em larga escala; b) suficiente heterose para produtividade (WEBER et alii, 1970; PASCHAL II \& WILCOX, 1975; KUNTA et alii, 1985). As evidências experimentais quanto a esses aspectos, indicaram que embora a variância aditiva seja o principal componente da variância hereditāria, os efeitos genéticos não aditivos podem contribuir significativamente para a variação de alguns caracteres em certas populações de soja. A heterose constitui-se em uma manifestação esperada dos efeitos não aditivos (BURTon, 1987). O autor relatou ainda que, não se conhece quanto do efeito heterótico é devido à dominância, aos tipos de epistasia envolvendo dominância e quanto poderia ser atribuído à epistasia aditiva $x$ aditiva. Provavelmente, uma linhagem homozigótica com comportamento equivalente à progénie $F_{1}$ poderia ser selecionada a partir das gerações segregantes. A probabilidade desta linhagem ser encontrada, 
entretanto, seria influenciada pelo nümero de genes envolvidos e pela relativa importância dos efeitos de dominância, os quais não podem ser fi xados e, também, pelos efeitos aditivo $\mathrm{x}$ aditivo que podem ser fixados. 0 autor concluiu que a identificação de tal linhagem seria difícil e de cus to elevado, se o caráter for influenciado por um grande número de genes e/ou se a dominância e os tipos de epistasia dominantes estiverem envolvidos significativamente. BURTON \& CARTER JUNIOR (1983) propuseram um mé todo para produção de sementes hỉbridas em quantidades experimentais. Todavia, a exploração comercial do vigor de híbrido em soja ainda è muito remota, devido principalmente à dificuldade de dispersão dos grãos-de-pōlen de uma planta para outra.

Verificou-se pelos resultados obtidos para produtividade e para os outros caracteres avaliados, que as diferenças observadas entre parentais e principalmente entre progênies $F_{2}$, como também, a variação das estimativas da heterose e da heterobeltiose, que esse grupo de parentais possui ampla variabilidade para todos os caracteres avaliados. Quanto à produtividade, existiu possibilidade de obtenção de combinações superiores visando futura utilização no cultivo de inverno.

\subsection{Anālise dialêlica de Griffing}

Na análise de variância apresentada na Tabela 2 constatou-se diferenças significativas ( $1 \%$ pelo teste "F") para tratamentos e para os desdobramentos em efeitos de parentais e de progênies $F_{2}$ para todos os caracteres avaliados. Essa significância indicou que hâ diferenças entre os genótipos. Procedeu-se então, à análise da capacidade de 
combinação, desdobrando-se a soma de quadrados de tratamentos em soma de quadrados para capacidade geral de combinação (CGC) e capacidade específi ca de combinação (CEC), de acordo com o método 2 , modelo misto $B$ de GRIFFING (1956).

A anālise de variância para CGC, CEC, relação entre CGC e CEC, e a média dos quadrados médios dos efeitos da CGC e CEC, para os nove caracteres estudados são apresentados na Tabela 6 . A capacidade geral de combinação (CGC) foi significativa (1\%) para oito caracteres, exceto para, ACM. Para capacidade especifica de combinação (CEC) não foi detectada significância para os caracteres avaliados. SPRAGUE \& TATUM (1942) e KEMPTHORNE \& CURNOW ( 1961) ressaltaram que a CGC decorre principalmente da variância genética aditiva e da variância epistática aditiva $x$ aditiva e que a CEC resulta da variância genêtica dominante e de vārios tipos de componentes da variância epistätica. Portanto, pode-se admitir que para os caracteres NDF, NIF, APF, NDM, NIM, APM, VAG e PPI, foram predominantemente controlados por ação gênica aditiva e possivelmen te por interação epistática aditiva $x$ aditiva.

A relação entre CGC e CEC foi avaliada segundo BAKER (1978) para o modelo com efeito de tratamentos fixos. Em oito caracteres a relação CGC/(CGC + CEC) foi superior a $93 \%$, sendo que a menor relação foi observada para ACM, que apresentou 89,5\%. KAW \& MENON (1981), PASCHAL II \& WILCOX (1975) e WEBER et alii (1970) obtiveram predominância da CGC em relação à CEC para produtividade, componentes da produtividade e outros caracteres na geração $F_{1}$. A mesma tendência tem sido observada para geração $\mathrm{F}_{2}$ : BHATADE et alii (1977) obteve relação de $79,4 \%$ e FREIRE 
FILHO (1988) estimou em $88,8 \%$ a participação da CGC para PPI.

Os resultados desse estudo evidenciaram maior importāncia da CGC em relação à CEC, estando de acordo com a literatura consultada. FREIRE FILHO (1988) e MIRANDA (1987) relataram que quando o conjunto de parentais è heterogêneo essa superioridade da CGC é esperada. A CEC não foi significativa nessa população; BAKER (1978) salientou que em tal situação, o comportamento de uma progênie pode ser adequadamente predito com base na capacidade geral de combinação. Para determinado carāter, a progênie mais promissora pode ser obtida através do cruzamento dos parentais que apresentarem os maiores valores para CGC (BAKER, 1978 e KAW \& MENON, 1981), A magnitude da CGC em relação à CEC enfatiza a ação gênica aditiva e possivelmente epistātica aditiva $\mathrm{x}$ aditiva para expressão dos caracteres avaliados. Os efeitos aditivo e aditivo $\mathrm{x}$ aditivo podem ser fixados em linhagens homozigöticas. Portanto, como afirmou BRIM (1973), quando o produto final de um programa de melhoramento são linhagens, a presença de epistasia aditiva $x$ aditiva significativa não deve alterar muito o programa, pois, o maior efeito da espitasia é tornar a avaliação precoce das progênies menos efetiva.

KUNTA et alii (1985) e PASCHAL II \& WILCOX (1975) constataram interações significativas, particularmente com anos. Porem, os autores concluíram que embora as interações tenham sido significativas, elas foram de pequena magnitude, podendo ser desprezadas. Este estudo foi rea lizado em um ano e em um único local; pode-se concluir que os dados obtidos em um ano e um local (não sendo atípicos) podem ser considerados satisfatórios para as estimativas da CGC e CEC. 


\subsubsection{Efeitos da CGC}

Os efeitos da capacidade geral de combinação $\left(g_{i}\right)$, os erros padrões de $g_{i}$ e de $\left(g_{i}-g_{j}\right)$, para os parentais em todos os caracteres avaliados são apresentados na Tabela 7 .

Quando se tem uma estimativa de $g_{i}$ com baixo valor abso1uto, o valor da CGC do parental, calculado com base em seus híbridos com os demais parentais, situa-se em torno da média da CGC de todos os parentais. Por outro lado, a estimativa de $g_{i}$ com alto valor absoluto indica que o parental em questão tem CGC superior ou inferior, respectivamente $g_{i}$ positivo e negativo, com relação ao comportamento médio dos cruzamentos (SPRAGUE \& TATUM, 1942).

Para o caráter $\mathrm{NDF}$, os valores de $g_{i}$ variaram de $-3,375$ a 2,951. Sete parentais apresentaram $g_{i}$ positivos, sobressaindo-se os parentais Cristalina, EMGOPA-301, IAC-6 e IAC-9, respectivamente com valores de 1,$216 ; 1,269 ; 2,951$ e 1,336 dias. Isto indicou que esses parentais contribuiram geneticamente com atrasos superiores a um dia para o inicio do florescimento. Os parentais IAC-4, IAC-5 e Santa Rosa, contribuíram no sentido de reduzir o inicio do florescimento em dois ou três dias, apresentando valores de $g_{i}$ de $-3,375 ;-2,115$ e $-2,617$, respectivamente.

A mesma tendência de valores positivos e negativos foi observada para o NIF, com exceção do parental IAC-8, que apresentou estimativa de $g_{i}$ negativa para $\operatorname{NIF}(-0,047)$. Os parentais Cristalina $(0,093)$, EMGOPA-301 $(0,019), \operatorname{IAC}-6(0,102), \operatorname{IAC}-9(0,079), \operatorname{IAC}-11(0,058)$ e SS-1 $(0,017)$, mostraram potencial para aumentar $\circ$ NIF. 
As estimativas de $g_{i}$ para APF variaram de $-5,749$ a $3,764 \mathrm{~cm}$, valor este apresentado pelo parental IAC-8, o qual mostrou o maior potencial para aumentar a APF. Os parentais IAC-4 e Santa Rosa contribuiram negativamente para esse carāter, reduzindo em aproximadamente 6 e $5 \mathrm{~cm}$ a $\mathrm{APF}$, respectivamente.

Para o carāter NDM, foi mantida a tendência das estimativas para $\mathrm{NDF}$, com sete parentais apresentando valores de $g_{i}$ positivos. Des tacaram-se os parentais Cristalina, EMGOPA-301, IAC-6 e IAC-9, respectivamente com $g_{i}$ de $5,597,2,631,3,471$ e 3,336 dias. Portanto, contribuindo geneticamente para atrasar o NDM atē aproximadamente seis dias, valor obtido para o parental Cristalina. No outro extremo está o parental IAC-4, com $g_{i}$ de $-7,243$ dias, o que representa uma contribuição média para reduzir en sete dias esse carāter.

No carāter NIM seis parentais apresentaram $g_{i}$ positivos. As estimativas variaram de $-0,201$ no parental IAC-4 a 0,237 no parental IAC-5. A estimativa de $g_{i}$ para o parental IAC-5 é relativamente alta, deve-se ressaltar que o mesmo, apresenta crescimento indeterminado. Esse resultado está de acordo com as estimativas obtidas por FREIRE FILHO (1988) .

Os parentais que mais contribuíram para aumentar a APM foram EMGOPA-301 e IAC-5, respectivamente com valores de $g_{i}$ de 4,183 e $9,642 \mathrm{~cm}$. Os parentais IAC-4 e Santa Rosa contribuíram com as maiores reduções para esse carāter, com $-9,591$ e -8,010 dias, respectivamente. 0 parental IAC-5 apresentou um comportamento interessante nos caracteres re lacionados à maturidade; com estimativa de $g_{i}$ negativa $(-3,198$ dias) para 
NDM e com maiores valores para os caracteres NIM e APM, respectivamente 0,237 e $9,642 \mathrm{~cm}$. Isso significou que o parental contribuiu simultaneamente para precocidade e para aumentar o NIM e a APM. FREIRE FILHO (1988) observou comportamento semelhante em parentais precoces, relacionando essas estimativas ao häbito de crescimento indeterminado do parental.

Para o carāter ACM, seis parentais apresentaram estimativas de $g_{i}$ negativas, indicando potencial genético para reduzir o ACM. As estimativas de $g_{i}$ variaram de $-0,089$ no parental IAC-4 a 0,143 no parental IAC-5. Verificou-se que, o parental com maior estimativa positiva de $g_{i}$ foi o que apresentou a maior contribuição para o aumento da APM.

A avaliação visual de vārios caracteres agronômicos simultaneamente, torna o VAG um caräter bastante complexo. Oito parentais apresentaram estimativas de $g_{i}$ positivas, sobressaindo-se os parentais Cristalina, EMGOPA-301, IAC-5, IAC-6 e IAC-8, respectivamente com valores de $0,052,0,050,0,041,0,043$ e 0,042, estimativas superiores ao erro padrão para o carāter. Os parentais com estimativas de $g_{i}$ positivas, pra ticamente mantiveram a mesma tendência para PPI, exceção feita ao parental IAC-6, que mudou de sinal de uma avaliação para outra. O VAG tende a refletir principalmente os componentes da produtividade, fato este vantajoso, visto que a produtividade geralmente é o caráter de maior interesse.

Para PPI, os parentais apresentaram estimativas que variaram de $-19,435$ no parental Santa Rosa a $14,094 \mathrm{~g} /$ planta no parental Cristalina. Os parentais Cristalina, IAC-11 e SS-1 foram os que apresentaram as maiores estimativas de $g_{i}$, respectivamente $14,094,7,347$ e 7,662 g/planta. 
Esses resultados indicaram que existiu potencial genético no sentido de contribuir com aumentos em torno de 7 a $14 \mathrm{~g}$ na PPI.

$$
\text { Verificou-se na Tabela } 7 \text {, que os parentais Cristalina, }
$$

SS-1 e IAC-11 destacaram-se com progênies $F_{2}$ mais produtivas visando ao cultivo de inverno. O parental Cristalina apresentou $g_{i}$ satisfatório para todos os caracteres com progênies seis dias mais tardias em maturidade, enquanto os parentais SS-1 e IAC-11 originaram progênies com estimativas de $g_{i}$ mais próximas da média de todos os genōtipos. HARTWIG (1970) sugeriu que sob condições de dias curtos, um mínimo de 45 dias entre a emergência e o início do florescimento è requerido para permitir o desenvolvimento vegetativo necessärio para produzir rendimento razoável; os resultados obtidos neste estudo confirmaram esta hipötese, pois em média foi observado um mínimo de 53 dias após semeadura para o início do florescimento nos parentais Cristalina, IAC-11 e SS-1.

A incorporação de genes para período juvenil longo nos cultivares foi salientada por FARIAS NETO (1987), como uma estratégia promissora para possibilitar que um mesmo genótipo tenha comportamento su perior e relativamente estāvel em diferentes épocas de cultivo. Uma anālise geral desse conjunto de parentais, evidenciou considerável variabilidade entre os mesmos, cujo potencial pode ser devidamente explorado, atravēs de intercruzamentos sucessivos para formação de uma população com ampla base genética. 


\subsubsection{Efeitos da CEC}

A interpretação do efeito da capacidade especifica de combinação, compreende o desvio de um hỉbrido em relação ao que seria esperado com base na CGC de seus parentais. Assim sendo, baixos valores abso lutos de $s_{i j}$ indicariam que os híbridos comportar-se-iam conforme o esperado a partir da CGC de seus parentais, enquanto, altos valores absolutos de $s_{i j}$ demonstrariam que o comportamento de um cruzamento particular é superior ( $s_{i j}$ positivo) ou inferior ( $s_{i j}$ negativo) ao esperado com base na CGC dos respectivos parentais.

As estimativas dos efeitos $s_{i i}$, que correspondem à CEC do parental $i$ com ele mesmo e os efeitos $s_{i j}$ que correspondem a CEC do parental $i$ com o parental $j$, são apresentados nas Tabelas 8 e 9 , respectivamente.

Vários autores utilizaram o método 2 de GRIFFING (1956), - qual inclui os hïbridos e os respectivos parentais, para anālise de cruzamentos dialélicos em soja (BHATADE et alii, 1977; KAW \& MENON, 1981; SRIVASTAVA et alii, 1978). Entretanto, os efeitos $s_{i i}$ não foram discutidos necessitando ainda de um significado genético mais realístico (MIRANDA, 1987)

De acordo com CRUZ \& VENCOVSKY ${ }^{1}$, os valores de $s_{i i}$ têm gran de significado genético, tanto no seu sinal quanto na sua magnitude

1 CRUZ, C.D. \& VENCOVSKY, R. (Universidade Federal de Viçosa, Viçosa, MG e Escola Superior de Agricultura "Luiz de Queiroz"/USP, Piracicaba, $\mathrm{SP}$ ) Comparação de alguns métodos de anālise dialélica. (Em elaboração). 
relativa. No modelo aditivo-dominante o estimador $s_{i i}$ é uma medida da divergência genética do parental i em relação à média dos outros parentais incluỉdos no dialelo. Esta divergência serā maior quanto maior for - valor absoluto de $s_{i i}$. Quando $s_{i i}$ for negativo, a heterose (em relação à média dos parentais) manifestada nos hỉbridos do parental i, será em média positiva; quando $s_{i i}$ for positivo, a heterose será em média negativa, e quando $s_{i i}$ for zero ou pröximo de zero a divergência do parental i em relação aos outros será pequena ou nula e a heterose nos híbridos do parental i será também pequena ou nula.

Com base na interpretação dada por CRUZ \& VENCOVSKY, as estimativas de $s_{i i}$ apresentaram grande variação para todos os caracteres (Tabela 8). Isso indicou que há uma considerável divergência entre os parentais, observando-se também que nenhum dos parentais apresentou os maiores ou menores valores absolutos de $s_{i i}$ para todos os caracteres. Verificou-se que parentais diferentes apresentaram os extremos de divergência genētica para os värios caracteres avaliados.

A proporção do nümero de parentais com valores $s_{i i}$ positivos e negativos variou com o caräter considerado. Valores de $s_{i i}$ predominantemente positivos foram observados apenas em dois caracteres $\quad 8: 2$ (NDF e NDM); para ambos os caracteres, a heterose média foi negativa (Ta belas 3 e 4). Para os outros caracteres foi observada predominância de valores de $s_{i i}$ negativos; $3: 7$ (NIF), $1: 9$ (APF), 3:7 (NIM), $4: 6$ (APM), $3: 7$ ( $\mathrm{ACM}$ ), 2:8 (VAG) e 2:8 (PPI), sendo que a heterose média foi positiva para os sete caracteres (Tabelas 3,4 e 5). Pode-se concluir que os resultados obtidos estão de acordo com as afirmativas de CRUZ \& VENCOVSKY. 
Na Tabela 9, são apresentados os resultados para CEC referentes aos efeitos $s_{i j}$ para $i \neq j$, ou seja, correspondente a um hibrido do cruzamento entre os parentais $i$ e $j$, para todos os caracteres avaliados. Verificou-se que as estimativas $s_{i j}$ apresentaram uma ampla variação para todos os caracteres. FREIRE FILHO (1988) ressaltou que em soja, onde o produto final do melhoramento são linhagens homozigóticas, as quais encerram somente efeitos aditivos e epistáticos aditivo $x$ aditivo, a importância da CEC depende da magnitude da proporção da variância epistātica aditiva $x$ aditiva que ela contēm. Nesse contexto, a CEC, por si sō, apresenta um valor limitado para o progresso de seleção. Assim sendo, deve-se considerar a CEC juntamente com outros parâmetros, tais como a média e a variância do híbrido, considerando-se uma geração segregante, e a CGC dos respectivos parentais.

No caräter NDF, visando-se florescimento tardio, os cruzamentos que apresentaram melhores valores para $s_{i j}$ foram IAC-6 $\mathrm{x}$ SS-1, Cristalina $\times$ IAC-11, IAC-6 $\times$ IAC-11, IAC-5 $\times$ Santa Rosa e IAC-6 $\times$ IAC-9, respectivamente com $1,925,1,747,1,583,1,183$ e 0,956 dias. Desses cruzamentos, os três mais tardios apresentaram estimativas de $g_{i}$ positivas para ambos os parentais e variâncias menores que a média da variância dos híbridos do dialelo. Vale ressaltar que entre os cruzamentos mais tardios para NDF, o parental IAC-6 participou em três combinações hĩbridas; esse parental foi em média o mais tardio e apresentou a melhor estimativa de $g_{i}$ para esse caräter (Tabelas 3 e 7 ).

As maiores estimativas de $s_{i j}$ para NIF foram apresentadas pelos cruzamentos Cristalina x EMGOPA-301, Cristalina x IAC-8, EMGOPA-301 $x$ 
Santa Rosa, Cristalina x IAC-6 e IAC-4 x Santa Rosa, respectivamente com $0,137,0,095,0,095,0,089$ e 0,088 . Entre os seis parentais envolvidos nesses cruzamentos, apenas Cristalina, EMGOPA-301 e IAC-6 apresentaram estimativas de $g_{i}$ positivas (Tabela 7 ).

Para APF, as maiores estimativas para $s_{i j}$ foram observadas nos cruzamentos Cristalina x EMGOPA-301, IAC-4 x IAC-5, Cristalina x IAC-8, IAC-8 x SS-1 e IAC-6 x SS-1, respectivamente com 9,902, 4,137, 3,313, 3,119 e 3,042. Verificou-se que esses cinco cruzamentos envolveram sete dos dez parentais avaliados e que cinco parentais (Cristalina, EMGOPA-301, IAC-6, IAC-8 e SS-1) apresentaram estimativas de $g_{i}$ positivas (Tabela 7). Os parentais com $g_{i}$ positivo originaram progênies $F_{2}$ com mëdias superiores e geralmente com variâncias de elevada magnitude, considerando-se a média e a variância do conjunto de híbridos (Tabela 3).

No carāter NDM, a maioria das estimativas de $s_{i j}$ foi negativa; isso estā de acordo com a tendência observada das progênies $F_{2}$ atingirem a maturidade antes que os parentais (mëdias e heterose média negativa, Tabela 4). As maiores estimativas de $s_{i j}$ foram obtidas nos cru zamentos IAC-6 $\mathrm{x}$ SS-1, Cristalina $\times$ IAC-11, IAC-5 $\times$ Santa Rosa, IAC-4 $\mathrm{x}$ Santa Rosa e Cristalina x IAC-9, respectivamente com 5,287, 2,750, 2,685, 2,329 e 2,299 dias. Entre os oito parentais que participaram desses cruzamentos, cinco apresentaram $g_{i}$ positivos (Tabela 7). As progênies originadas dos parentais Cristalina, IAC-6, IAC-9, IAC-11 e SS-1 ( $g_{i}$ positivos) apresentaram médias superiores e variâncias inferiores ao conjunto de hỉbridos. Entretanto, foram observados cruzamentos com média em torno do conjunto de progênies $F_{2}$, porém com variâncias de elevada magnitude, 
caso dos cruzamentos Cristalina x SS-1, EMGOPA-301 x SS-1, IAC-5 x SS-1, IAC-9 $\times$ SS-1 e IAC-11 × SS-1. Percebe-se que além de participar da combinação hỉbrida de maior estimativa para $s_{i j}$, o parental sS-l deu origem a progênies $\mathrm{F}_{2}$ com variâncias relativamente altas com praticamente todos os parentais envolvidos no esquema dialêlico.

Para NIM, os cruzamentos IAC-5 x IAC-11 com estimativa de 0,146, Cristalina $\times$ EMGOPA-301 de 0,101, IAC-4 x IAC-8 de 0,092, IAC-5 $x$ IAC- 6 de 0,087 e IAC-5 5 IAC- 8 de 0,082 , foram os que apresentaram os maiores efeitos da CEC. Cinco parentais desses cruzamentos apresentaram estimativas de $g_{i}$ positivas (Tabela 7 ). Nota-se que dos cinco cruzamentos de maior efeito $s_{i j}$ para NIM, o parental IAC-5 participou em três combinações e que as progênies $F_{2}$ nas quais esteve envolvido, apresentaram as médias e variâncias mais elevadas dos cruzamentos avaliados (Tabela 4 ).

No carāter APM, a maioria das estimativas de $s_{i j}$ foram positivas e os valores mais expressivos foram apresentados pelos cruzamentos Cristalina $x$ EMGOPA-301, IAC-5 x IAC-11, Cristalina $x$ IAC-8, EMGOPA-301 x IAC-5 e IAC-5 x IAC-6, respectivamente com 10,345, 6,811, $4,640,4,039$ e $3,642 \mathrm{~cm}$. Os seis parentais que participaram desses cruzamentos apresentaram estimativas de $g_{i}$ positivas (Tabela 7 ). Os cruzamentos IAC-5 x IAC-11 e Cristalina x EMGOPA-301 obtiveram as maiores médias para APM, os demais cruzamentos tambēm apresentaram médias superiores ao conjunto de progênies $\mathrm{F}_{2}$. As variâncias observadas foram iguais ou superiores à média da variância de todos os cruzamentos (Tabela 4). 
Para ACM, houve um equilíbrio quanto ao número de estimativas de $s_{i j}$ positivas e negativas. Os cruzamentos Cristalina $x$ IAC-6, IAC-8 x Santa Rosa, EMGOPA-301 x SS-1, IAC-9 x IAC-11, Cristalina x IAC-11 e IAC-8 x IAC-11 apresentaram os melhores valores de $s_{i j}$, respectivamente $-0,158,-0,150,-0,143,-0,097,-0,092$ e $-0,092$. Nesses cruzamentos, participaram oito parentais e todos eles reuniram um parental com $g_{i}$ positivo e outro com $g_{i}$ negativo, exceto os cruzamentos Cristalina x IAC-11. e IAC-9 $\times$ IAC-11, nos quais ambos os parentais apresentaram $g_{i}$ negativos (Tabela 7). A média desses cruzamentos foi sempre inferior à média dos cruzamentos do dialelo; as variâncias situaram-se em torno da média das variâncias dos cruzamentos, com exceção do cruzamento IAC-9 x IAC-11. Para ○ ACM, médias pröximas de 1,0 são de interesse, visto que a nota 1,0 foi atribuida a uma planta ereta (Tabela 5).

Para o carāter VAG, os cruzamentos que apresentaram as me1hores estimativas de $s_{i j}$ foram IAC-4 $\times$ IAC-5, IAC-5 $\times$ IAC-11, Cristalina $\times$ EMGOPA-301, IAC-8 $\times$ IAC-9 e EMGOPA-301 × IAC-9, respectivamente com valores de $0,108,0,077,0,067,0,052$ e 0,051 . As estimativas de $g_{i}$ foram positivas para ambos os parentais, com exceção do cruzamento IAC-4 $x$ IAC-5, onde o parental IAC-4 apresentou $g_{i}$ negativo e o parental IAC-5 $g_{i}$ positivo (Tabela 7). A mëdia desses cruzamentos foi igual (IAC-4 $x$ IAC-5) ou superior à média dos cruzamentos do dialelo. As variancias dos cruzamentos IAC-4 × IAC-5 e IAC-8 × IAC-9 foram inferiores e os cruzamentos IAC-5 x IAC-11, Cristalina x EMGOPA-301 e EMGOPA-301 x IAC-9 apresentaram variâncias superiores à média das variâncias dos cruzamentos dialélicos (Tabela 5). 
No carāter PPI, dos dez cruzamentos que apresentaram os maiores valores de $s_{i j}$, oito envolveram parentais com estimativas positivas para $g_{i}$ e dois tiveram parentais com sinais diferentes para $g_{i}$. Os cinco cruzametos que apresentaram os valores mais expressivos para os efeitos $s_{i j}$ foram Cristalina $x$ IAC-6, Cristalina $x$ EMGOPA-301, IAC-5 $x$ IAC-11, IAC-8 × IAC-9 e IAC-9 x SS-1, respectivamente com valores de 19,0, $13,8,12,5,11,9$ e 9,6 g/planta. Esses cruzamentos apresentaram médias superiores à mëdia geral dos cruzamentos e com exceção do cruzamento IAC-8 $\times$ IAC-9, tiveram variâncias maiores que a média das variâncias do dialelo (Tabela 5). Vale registrar, que embora apresentando baixos efeitos de CEC, hä outros cruzamentos como Cristalina x IAC-9, Cristalina $x$ IAC-11, Cristalina $\times$ SS-1, EMGOPA-301 x IAC-11, IAC-5 x IAC-9, IAC-5 x SS-1, IAC-8 $\times$ SS-1 e IAC-11 $\times$ SS-1, que apresentaram mëdia de PPI e particularmente variâncias superiores aos cruzamentos que apresentaram os valores mais expressivos para CEC. Verificou-se que nos cruzamentos citados, principalmente no ültimo grupo, sobressairam-se os parentais Cristalina, IAC-11 e SS-1; sendo os mesmos, os parentais que apresentaram as maiores estimativas de $g_{i}$ para a produtividade de planta individual (Tabela 7). Esses resultados indicaram que os parentais Cristalina, IAC-11 e SS-1, assim como os cruzamentos dos quais eles participaram, mostraram-se como os mais promissores para o melhoramento para produtividade visando o cultivo de inverno.

Para todos os caracteres avaliados, os cruzamentos que mais se destacaram em termos de efeitos $s_{i j}$, reuniram parentais com efeitos da CGC de mesmo sentido, sendo que a maioria dos parentais apresentou estimativa de $g_{i}$ positiva. Nesse estudo, as maiores estimativas de 
$s_{i j}$ para a maioria dos caracteres, geralmente estiveram relacionadas às maiores médias e estimativas de $g_{i}$, entretanto nem sempre corresponderam às maiores variâncias. Desse modo, a CEC mostrou-se relativamente pouco vą liosa para a identificação dos melhores parentais e cruzamentos.

Como foi salientado por SPRAGUE \& TATUM (1942) e KEMPTHORNE \& CURNOW (1961), a CEC é dependente da variância dominante e dos efeitos epistāticos, entre os quais se inclui as interações com dominância. 0 objetivo final do melhoramento em soja, que é uma espécie autógama, é a obtenção de linhagens homozigóticas. Assim, a importância da CEC depende da magnitude da contribuição da interação epistätica aditiva $x$ aditiva que ela contēm. Porém, como ressaltou FREIRE FILHO (1988), a epistasia depende da interação interalëlica, sendo instāvel em gerações segregantes e podendo ter seus efeitos anulados em decorrência da segregação. Desse modo, para se explorar melhor os efeitos da CEC em soja, as avaliações da capacidade específica de combinação devem ser realizadas em gerações mais avançadas.

\subsection{Comparação dos tipos de parcelas experimentais}

A instalação de três experimentos com diferentes tipos de parcelas possibilitou a comparação de parentais e de progênies $F_{2}$ em värios arranjos experimentais. A Tabela 10 apresenta as correlações fenotipicas dos parentais, progênies $F_{2}$ e de ambos em conjunto, em três arran jos experimentais distintos para os nove caracteres avaliados. 
Os resultados observados apresentam correlações significativas para todos os caracteres, exceto para ACM, nos diferentes tipos de parcelas. Vale salientar, que nos caracteres relacionados ao florescimento e à maturidade, a utilização de covas individuais foi bastante eficiente. Para a avaliação da produtividade (PPI) a maioria das correlações foram significativas, sendo que as comparações onde não foi detectada significância, os resultados observados situaram-se muito próximos do limite de $5 \%$ de probabilidade pelo teste " $t$ ". Os dados obtidos indicaram a possibilidade da utilização de diferentes tipos de parcelas experimentais na avaliação de populações segregantes; particularmente o emprego de covas individuais mostrou-se bastante satisfatório em discriminar os cruzamentos mais promissores para o cultivo de inverno.

0 processo de avaliação deve incluir tantos genōtipos quan to possível para aumentar a chance de obtenção de combinações superiores. Este processo deve ser suficientemente preciso para separar diferenças genéticas do erro experimental e da interação genōtipo x ambiente. FEHR (1987) salientou duas vantagens da utilização de parcelas em covas sobre fileiras: a) obtenção de sementes suficientes a partir de uma planta para testes com repetições sem a necessidade de uma geração adicional para aumentar a quantidade de sementes; b) menor ārea por parcela, sendo importante quando um grande número de genótipos são avaliados. GARLAND \& FEHR (1981) relataram que as parcelas em covas são mais vantajosas no tes te inicial para avaliar o potencial de produção das progênies; entretanto, as covas não devem ser consideradas como um substituto para as fileiras nos testes em fases mais avançadas. 
5. CONCLUSÕES

Para as condições em que foi realizado este estudo, pôdese concluir:

a) 0 comportamento dos parentais per se e a heterose média observada nos cruzamentos, indicaram que os cultivares utilizados nesse trabalho, representam um conjunto geneticamente promissor para programas de melhoramento visando ao cultivo de inverno.

b) A variabilidade genética variou entre os cruzamentos e entre os nove caracteres avaliados. Nenhum cruzamento apresentou variância superior em todos os caracteres, suge rindo que os parentais possuem caracteristicas complementares.

c) A heterose e a heterobeltiose apresentaram ampla variação; geralmente as maiores estimativas para heterose e heterobeltiose estiveram relacionadas às maiores 
médias; entretanto, nem sempre corresponderam às maiores variâncias. Em termos de PPI, 16 progênies $F_{2}$ superaram o parental mais produtivo (SS-1), evidenciando heterose padrão para PPI na geração $\mathrm{F}_{2}$.

d) A capacidade geral de combinação (CGC) foi mais importante que a capacidade específica de combinação (CEC). A magnitude desta relação enfatiza a ação gênica aditiva e possivelmente a epistasia aditiva $\mathrm{x}$ aditiva para a expressão dos caracteres avaliados.

e) Os maiores valores de $g_{i}$ ocorreram em parentais diferentes para os värios caracteres avaliados, indicando a complementação de caracteres nos parentais. As maiores estimativas de $s_{i j}$ reuniram parentais com $g_{i}$ positi vos; estiveram relacionadas às maiores médias e estimativas de $g_{i}$, mas nem sempre corresponderam às maiores variâncias.

f) Com base nas médias e na capacidade de combinação, prin cipalmente nos efeitos da CGC, os parentais Cristalina, IAC-11 e SS-1, assim como os cruzamentos dos quais eles participaram, apresentaram maior potencial para o melho ramento da produtividade de grãos visando ao cultivo de inverno. 
g) Os parentais apresentaram complementação de caracteres e considerável variabilidade genética para formação de população básica a ser utilizada em programas de seleção recorrente, objetivando o desenvolvimento de genótipos com periodo juvenil acentuado e com maior produti vidade de grãos para o cultivo de inverno ou em baixas latitudes.

h) A utilização de covas individuais para avaliação das progênies $\mathrm{F}_{2}$ mostrou-se bastante satisfatöria em discriminar os cruzamentos mais promissores. 
BIBLIOGRAFIA

ABEL JUNIOR, G.H. Response of soybean to dates of planting in the imperial valley of California. Agronomy Journat, Madison, 53:95-8, 1961.

BAKER, R.J. Issues in diallel analysis. Crop Science, Madison, 18:533-6, 1978.

BERNARD, R.L. Two major genes for time of flowering and maturity in soybeans. Crop Science, Madison, 11:242-4, 1971.

BHATADE, S.S.; SINGH, C.B.; TIWARI, A.S. Diallel analysis of yield and its components in soybean. Indian Journal Agricultural Science, New Delhi, 47:322-4, 1977 .

BOARD, J.E. \& HALL, W. Premature flowering in soybean yield reductions at nonoptimal planting dates as influenced by temperature and photoperiod. Agronomy JournaZ, Madison, 76:700-4, 1984. 
BONATO, E.R. \& DALL'AGNOLL, A. Soybean in Brazil-Production and research. In: WORLD SOYBEAN RESEARCH CONFERENCE, 3., Ames, 1984. Proceedings. Boulder, Westview Press, 1985. p.1248-56.

BORTHWICK, H.A. \& PARKER, M.W. Effectiveness of photoperiodic treatments of plants of different age. Botanical Gazette, Chicago, 100:245-9, 1938a.

BORTHWICK, H.A. \& PARKER, M.W. Photoperiodic perception in Biloxi soybeans . Botanical Gazette, Chicago, 100:374-87, $1938 \mathrm{~b}$.

BORTHWICK, H.A. \& PARKER, M.W. Photoperiodic responses of several varieties of soybeans. Botanical Gazette, Chicago, 101:341-65, 1939.

BORTHWICK, H.A. \& PARKER, M.W. Floral initiation in Biloxi soybean influenced by age and position of leaf. Botanical Gazette, Chicago, $101: 806-17,1940$.

BRIM, C.A. Quantitative genetics and breeding. In: CALDWELL, B.E., ed. Soybecns; improvement, production, and uses. Madison, American Society of Agronomy, 1973. p.155-86.

BURTON, J.W. Quantitative genetics; results relevant to soybean breeding. In: WILCOX, J.R. Soybeans; improvement, production and uses. Madison, American Society of Agronomy, 1987. p.211-47. 
BURTON, J.R. \& CARTER JUNIOR, T.E. A method for production of experimental quantities of hybrid soybean seed. Crop Science, Madison, 23:388-90, 1983.

BUZZELL, R.I. Inheritance of a soybean flowering response to fluorescentdaylength conditions. Canadian Journal of Genetics and Cytology, Ottawa, 13:703-7, 1971.

BUZZELL, R.I. \& VOLDENG, H.D. Inheritance of insensitivity to long daylength. Soybean Genetics Newsietter, Ames, 7:26-9, 1980.

BYTH, D.E. Comparative photoperiodic responses for several soybean varieties of tropical and temperate origin. Australian Journal Agricultural Research, Melbourne, 19:879-90, 1968.

CAMPOS, L.A.C. Estudo da heterose, da herdabilidade e de correlações de algumas características agronômicas em cruzamentos de soja (Glycine $\max ($ I.) Merrill). Viçosa, 1979. 76p. (M.S. - Universidade Federal de Viçosa)

CHAUDHARY, D.N. \& SINGH, B.B. Heterosis in soybean. Indian Joumal of Genetics \& Plant Breeding, New Delhi, 34:69-74, 1974.

CHAUHAN, V.S. \& SINGH, B.B. Heterosis and genetic variability in relation to genetic divergence in soybean. Indian Journal of Genetics \& Plant Breeding, New Delhi, 42:324-8, 1982 . 
CHIPALA, E. Utilization of a juvenile trait in soybeans (Glycine $\max$ (L.) Merri11). Dissertation Abstracts International. Séries B, Annarbor, 45:1963, 1985.

CONSTABLE, G.A. Effect of planting date on soybeans in the namoi valley, new south wales. Australian Joumal of Experimental Agriculture and Animal Husbandry, Melbourne, 17:148-55, 1977.

CREGAN, P.B. \& HARTWIG, E.E. Characterization of flowering response to photoperiod in diverse soybean genotypes. Crop Science, Madison, 24: $659-62,1984$.

CRISWELL, G.J. \& HUME, D.J. Variation in sensitivity to photoperiod among early maturing soybean strains. Crop Science, Madison, 12:657-60, 1972 .

ECKHART, R.C. Predicting yields of missing single crosses of corn. Agronomy Journal, Madison, 44:215-6, 1952.

ESCOLA SUPERIOR DE AGRICULTURA "LUIZ DE QUEIROZ". Departamento de Física e Meteorologia. Análise dos dados meteorológicos de Piracicaba. Piracicaba, 1975. 23p. (Boletim Técnico Científico, 32).

FALCONER, D.S. Introdução à genética quantitativa. Viçosa, Imprensa Universitária da Universidade Federal de Viçosa, 1987. 279p. 
FAO PRODUCTION YEARBOOK 1985. Rome, 39:142, 1986.

FARIAS NETO, J.T. Comportamento e variabilidade de genótipos de soja (Glycine $\max$ (L.) Merri11) em cultivos de verão e inverno. Piracicaba, 1987. 87p. (Mestrado - Escola Superior de Agricultura "Luiz de Queiroz"/USP)

FEHR, W.R. Breeding methods for cultivar development. In: WILCOX, J.R. Soybeans; improvement, production and uses. Madison, American Society of Agronomy, 1987. p.249-93.

FRANCIS, C.A. Effective day lengths for the study of photoperiod sensitive reactions in plants. Agronomy Journal, Madison, 62:790-2, 1970.

FREIRE FILHO, F.R. Anālise genética de um dialelo entre genótipos precoces de soja (Glycine max (L.) Merrill). Piracicaba, 1988. 224 p. (Doutorado - Escola Superior de Agricultura "Luiz de Queiroz"/USP)

GANDOLFI, V.H.; SOUZA, B.H. de; MULLER, I. Efeitos de diferentes termoperiodicidades sobre desenvolvimento de cultivares de soja (Glycine $\max$ (L.) Merril1) em condições de dias curtos. Agronomia SuZriograndense, Porto Alegre, 15:33-51, 1979. 
GANDOLFI, V.H.; MULLER, L.; MINOR, H.C.; BERLATO, M.A. Identificação de cultivares de soja (Glycine max (L.) Merrill) menos sensiveis ao fotoperíodo entre cultivares tardias. Agronomia SuZriograndense, Porto Alegre, 13:63-82, 1977.

GARLAND, M.L. \& FEHR, W.R. Selection for agronomic characters in hill and row plots of soybeans. Crop Science, Madison, 21:591-5, 1981.

GARNER, W.W. \& ALLARD, H.A. Effect of the relative length of day and night and other factor of the environment on growth and reproduction in plants. Journal of Agricultural Research, Washington, 18:553-606, 1920.

GARNER, W.W. \& ALLARD, H.A. Photoperiodic response of soybeans in relation to temperature and other environmental factors. Journal of Agricultural Research, Washington, 41:719-35, 1930.

GILIOLI, J.L.; SEDIYAMA, T.; FONSECA JUNIOR, N. Herança do número de dias para a floração em quatro mutantes naturais de soja, estudada sob condições de dias curtos. In: SEMINARIO NACIONAL DE PESQUISA DE SOJA, 3., Campinas, 1984. Anais. Londrina, EMBRAPA/CNPSo, 1984. p.323-37.

GRIFFING, B. Concept of general and specific combining ability in relation to diallel crossing systems. Australian Joumal of Biological Sciences, Melbourne, 9:463-93, 1956. 
HARTWIG, E.E. Factors affecting time of planting soybeans in the southern states. Washington, USDA, 1954. 13p.

HARTWIG, E.E. Time of planting soybeans in the south. Soybean Digest, Hudson, $18: 16-9,1958$.

HARTWIG, E.E. Growth and reproductive characteristics of soybeans (Glycine max (L.) Merril1) grown under short-day conditions. Tropical Science, London, 12:47-53, 1970.

HARTWIG, E.E. Varietal development. In: CALDWELL, B.E., ed. Soybeans; improvement, production, and uses. Madison, American Society of Agronomy, 1973. p.187-210.

HARTWIG, E.E. Some inter-relationships between days to first bloom and days to maturity. Soybean Genetics Newsletter, Ames, 2:26-8, 1975.

HARTWIG, E.E. \& KIIHL, R.A.S. Identification and utilization of a delayed flowering character in soybeans for short-day conditions. Field Crops Research, Amsterdam, 2:145-51, 1979.

HIROMOTO, D.M. \& VELLO, N.A. The genetic base of Brazilian soybean (Glycine max (L.) Merrill) cultivars. Revista Brasileira de Genëtica, Ribeirão Preto, 9:29.5-306, 1986. 
HOWELL, R.W. Physiology of the soybean. In: NORMAN, A.G., ed. The soybean. New York, Academic Press, 1963. p.75-124.

HUXLEY, P.A. \& SUMMERFIELD, R.J. Effects of night temperature and photoperiod on the reproductive ontogeny of cultivars of cowpea and of soybean selected for the wet tropics. Plant Science Letters, Amsterdam, $3: 11-7,1974$.

JOHNSON, H.W.; BORTHWICK, H.A.; LEFFEL, R.C. Effects of photoperiod and time of planting on rates of development of the soybean in various stages of the life cycle. Botanical Gazette, Chicago, 122:77-95, 1960 .

KAW, R.N. \& MENON, P.M. Heterosis in a ten-parental diallel cross in soybean. Indian Journal of Agricultural Sciences, New Delhi, 49:322-4, 1979.

KAW, R.N. \& MENON, P.M. Combining ability for developmental traits in soybean. Indian Journal of Genetics \& Plant Breeding, New Delhi, 41: $303-8,1981$.

KEMPTHORNE, O. \& CURNOW, R.N. The diallel cross. Biometrics, Raleigh, $17: 229-50,1961$. 
KIIHL, R.A.S. Inheritance studies of two characteristics in soybean (Glycine $\max ($ L.) Merrill); I. Resistance to soybean mosaic virus;

II. Late flowering under short-day conditions. Mississipi, 1976. 56p. (Ph.D. - Mississipi State University)

KIIHL, R.A.S.; ALMEIDA, L.A.; DALL'AGNOLL, A. Strategies for cultivar development in the tropics. In: WORLD SOYBEAN CONFERENCE, 3., Ames, 1984. Proceedings. Boulder, Westview Press, 1985. p.301-4.

KIIHL, R.A.S.; ALMEIDA, L.A.; CAMPELO, G.J.A.; BAYS, I.A.; GOMES, E.R.; ROLIM, R.B.; MONTEIRO, P.M.F.O.; MIRANDA, M.A.C. Tropical uma cultivar brasileira para as baixas latitudes. In: SEMINĀRIO NACIONAL DE PESQUISA DE SOJA, 2., Brasília, 1981. Anais. Londrina, EMBRAPA/CNPSo, 1982. v.2, p.493-4.

KUNTA, T.; EDWARDS, L.H.; MCNEW, R.W.; DINKINS, R. Heterosis performance and combining ability in soybeans. Soybean Genetics Newsletter, Ames, $12: 97-9,1985$.

LAWN, R.J. \& BYTH, D.E. Response of soybeans to planting date in SouthEastern Queensland; I. Influence of photoperiod and temperature on phasic developmental patterns. Australian Joumal Agricultural Research, Melbourne, 24:67-80, 1973.

LEFFEL, R.C. \& HANSON, W.D. Early generation testing of diallel crosses of soybeans. Crop Science, Madison, 1:169-74, 1961. 
MAJOR, D.J.; JOHNSON, D.R.; TANNER, J.W.; ANDERSON, I.C. Effects of daylength and temperature on soybean development. Crop Science, Madison, $15: 174-9,1975$.

MCBLAIN, B.A. \& BERNARD, R.L. A new gene affecting the time of flowering and maturity in soybeans. The Journal of Heredity, Washington, 78: $160-2,1987$.

MIRANDA, J.E.C. Anālise genética de um cruzamento dialélico em pimentão (Capsicum annum L.). Piracicaba, 1987. 159p. (Doutorado-Escola Superior de Agricultura "Luiz de Queiroz"/USP)

MIRANDA, M.A.C.; MIYASAKA, S.; MASCARENHAS, H.A.A.; ROSSETTO, D. Melhoramento da soja no Estado de São Paulo. In: FUNDAÇÃo CARGILL. A soja no Brasiz Central. Campinas, 1977. p.23-54.

MIYASAKA, S.; GUIMARÃES, G.; KIIHL, R.A.S.; LOVADINI, L.A.C.; DEMATTÊ, J.D. Variedades de soja indiferentes ao fotoperiodo e tolerantes a baixas temperaturas. Bragantia, Campinas, 29:169-73, 1970.

NISSLY, C.R.; BERNARD, R.L.; HITTLE, C.N. Daylength sensitivity studies with maturity group III soybean germplasm. Soybean Genetics Newsletter, Ames, 2:14-5, 1975. 
NISSLY, C.R.; BERNARD, R.L.; HITTLE, C.N. Variation in photoperiod sensitivity for time of flowering and maturity among soybean strains of maturity group III. Crop Science, Madison, 21:833-6, 1981.

OSLER, R.D. \& CARTTER, J.L. Effect of planting date on chemical composition and growth characteristics of soybeans. Agronomy Journal, Madison, $46: 267-9,1954$.

PARKER, M.W.; HENDRICKS, S.B.; BORTHWICK, H.A.; SCULLY, N. J. Action spectrum for the photoperiodic control of floral initiation of shortday plants. Botanical Gazette, Chicago, 108:1-26, 1946.

PASCHAL II, E.H. \& WILCOX, J.R. Heterosis and combining ability in exotic germplasm. Crop Science, Madison, 15:344-9, 1975.

PATERNIANI, E. Estudos recentes sobre heterose. São Paulo, Fundação Cargi11, 1974. 36p. (Boletim, 1).

PIMENTEL GOMES, F. Curso de estatistica experimental. 11. ed. São Pau1o, Nobe1, 1985. 466p.

POLSON, D.E. Day-neutrality in soybeans. Crop Science, Madison, 12:773-6, 1972. 
RANZANI, G.; FREIRE, o.; KINJO, T. Carta de solos do municipio de Piracicaba. Piracicaba, ESALQ/Centro de Estudos de Solos, 1966. 86p. (mimeografado).

ROBERTS, R.H. The role of night temperature in plant performance. Science, Lancaster, 98:265, 1943.

SCHAIK, P.H. van \& PROBST, A.H. Effects of some environmental factors on flower production and reproductive efficiency in soybeans. Agronomy Journal, Madison, 50:192-7, 1958.

SEDDIGH, M. \& JOLLIFF, G.D. Night temperature effects on morphology, phenology, yield and yield components of indeterminate field-grown soybean. Agronomy Journal, Madison, 76:824-8, 1984.

SHANMUGASUNDARAM, S. Variation in the photoperiodic response to flowering in soybean. Soybean Genetics Newsietter, Ames, 5:91-4, 1978.

SHANMUGASUNDARAM, S. Variation in the photoperiodic response on several characters in soybean, Glycine $\max$ (L.) Merril1. Euphytica, Wageningen, $28: 495-507,1979$.

SHANMUGASUNDARAM, S. \& WANG, C.C. Decapitation technique to screen for photoperiod insensitivity in soybean. Glycine $\max$ (L.) Merrill. Soybean Genetics Newsietter, Ames, 4:13-5, 1977. 
SHANMUGASUNDARAM, S. \& TSOU, S.C.S. Photoperiod and critical duration for flower induction in soybean. Crop Science, Madison, 18:598-601, 1978.

SINGH, M.P. \& ANDERSON, J.C. Inheritance of earlyness of maturity in soybean, Glycine $\max$ (I.) Merri11. Agronomy Journal, Madison, 41: $477-83,1949$.

SOUZA, P.I.M. de; SPEHAR, C.R.; URBEN FILHO, G.; VILELA, L.; ZUFFO, N.L.; ARANTES, N.E.; MONTEIRO, P.M.O.F.; KIIHL, R.A. BR-9. (Savana); uma nova cultivar de soja para os cerrados. In: SEMINÁRIO NACIONAL DE PESQUISA DE SOJA, 3., Campinas, 1984. Anais. Londrina, EMBRAPA/CNPSo, 1984. p.401-5.

SPRAGUE, G.F. \& TATUM, L.A. General vs. specific combining ability in single cross of corn. Journal of the American Society of Agronomy, Geneva, $34: 923-32,1942$.

SRIVASTAVA, R.L.; SAXENA, J.K.; AHMAD, Z.; BHATIA, R.S. Genetics of yield and yield component traits in soybean. Indian Joumal of Genetic \& Plant Breeding, New Delhi, 38:6-10, 1978.

THOMAS, J.F. \& RAPER JUNIOR, C.D. Morphological response of soybeans as governed by photoperiod, temperature, and age at treatment. Botanical Gazette, Chicago, 138:321-8, 1977. 
THOMAS, J.F. \& RAPER JUNIOR, C.D. Effect of day and night temperatures during floral induction on morphology of soybeans. Agronomy Journal, Madison, $70: 893-8,1978$.

TISSELI JUNIOR, 0 . Inheritance study of the long-juvenile characteristic in soybeans under long- and short-day conditions. Mississipi, 1981. 77p. (Ph.D. - Faculty of Mississipi State University)

TOLEDO, J.F.F. \& KIIHL, R.A.S. Métodos de anälise dialélica do modelo genético em controle das características dias para floração e número de folhas trifolioladas em soja. Pesquisa Agropecuäria Brasileira, Brasilia, $17: 745-55,1982$.

VEATCH, C. Vigor in soybeans as affected by hybridity. Journal of the American Society of Agronomy, Madison, 22:289-310, 1930.

VELLO, N.A. Efeitos da introdução de germoplasma exótico sobre a produtividade e relaçōes com a base genética dos cultivares de soja (Glycine $\max ($ L.) Merri11). Piracicaba, 1985. 91p. (Livre-Docência-Escola Superior de Agricultura "Luiz de Queiroz"/USP)

VELLO, N.A.; HIROMOTO, D.M.; AZEVEDO FILHO, A.J.B.V. Coefficient of parentage and breeding of Brazilian soybean germplasm. Revista BrasiZeira de Genética. Ribeirão Preto, 11:679-97, 1988. 
VILELA, L.; SPEHAR, C.R.; SOUZA, P.I.M.; VIEIRA, R.D. Comportamento de cultivares de soja em época seca (inverno) no cerrado do Distrito Federa1. In: SEMINÁRIO NACIONAL DE PESQUISA DE SOJA, 1., Londrina, 1978. Anais. Londrina, EMBRAPA/CNPSo, 1979. v.1., p.357-63.

WANG, C.L.; MON, C.S.; TSU, C.C. Photoperiodic response of wild soybeans collected from localities of different latitude in China. Soybean Genetics Newsletter, Ames, 7:32-5, 1980.

WEBER, C.R.; EMPIG, L.T.; THORNE, J.C. Heterotic performance and combining ability of two-way $\mathrm{F}_{1}$ soybean hybrids. Crop Science, Madison, $10: 159-60,1970$.

WEISS, M.G.; WEBER, C.R.; KALTON, R.R. Early generation testing in soybeans. Joumal of the American Society of Agronomy, Madison, 39: $791-811,1947$

WENTZ, J.B. \& STEWART, R.T. Hybrid vigor in soybeans. Journal of the American Society of Agronomy, Madison, 16:534-40, 1924.

WHIGHAM, D.K. \& MINOR, H.C. Agronomic characteristics and environmental stress. In: NORMAN, A.G., ed. Soybean; physiology, agronomy, and utilization. New York, Academic Press, 1978. p.77-116. 
T A B E L A S 


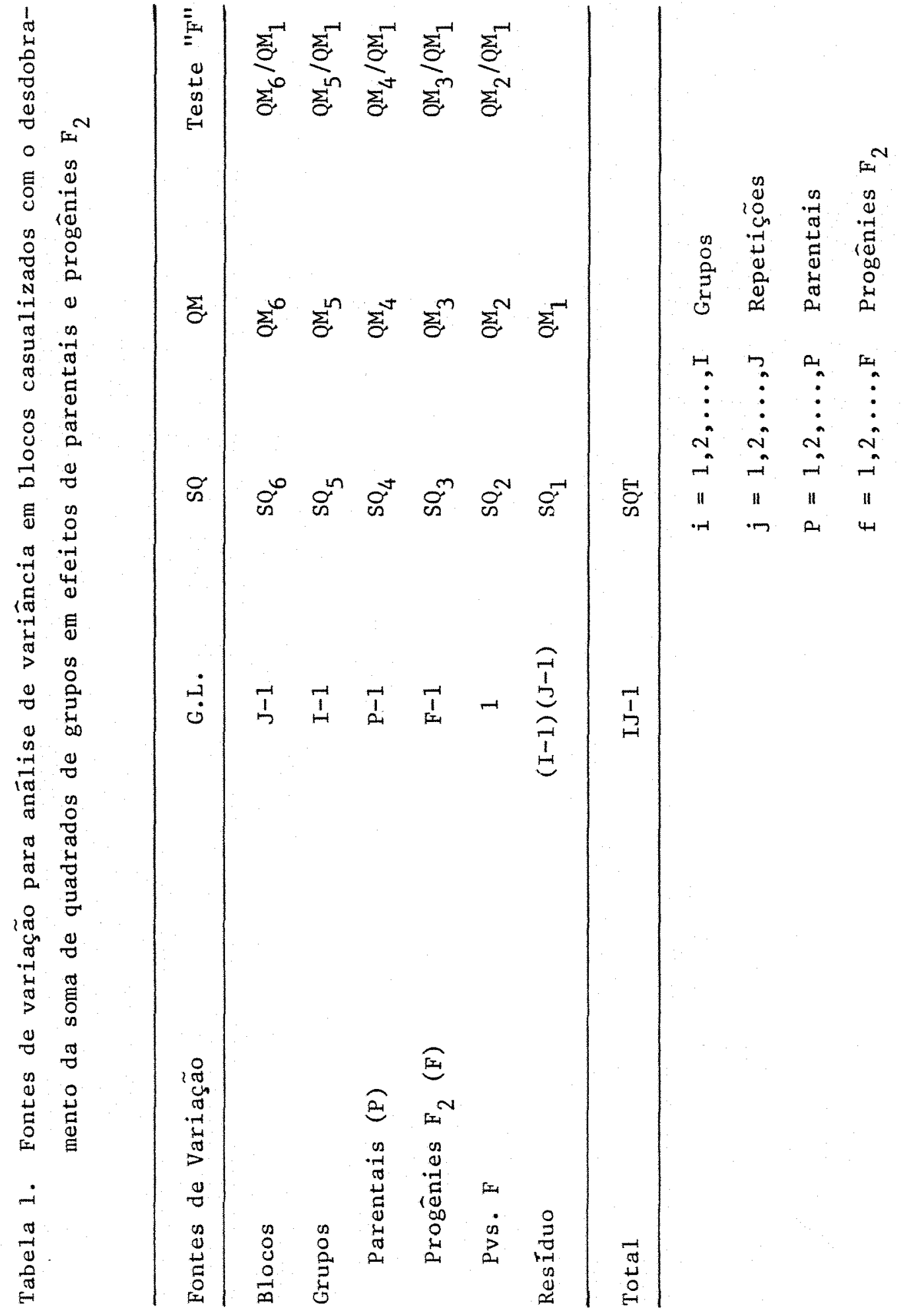



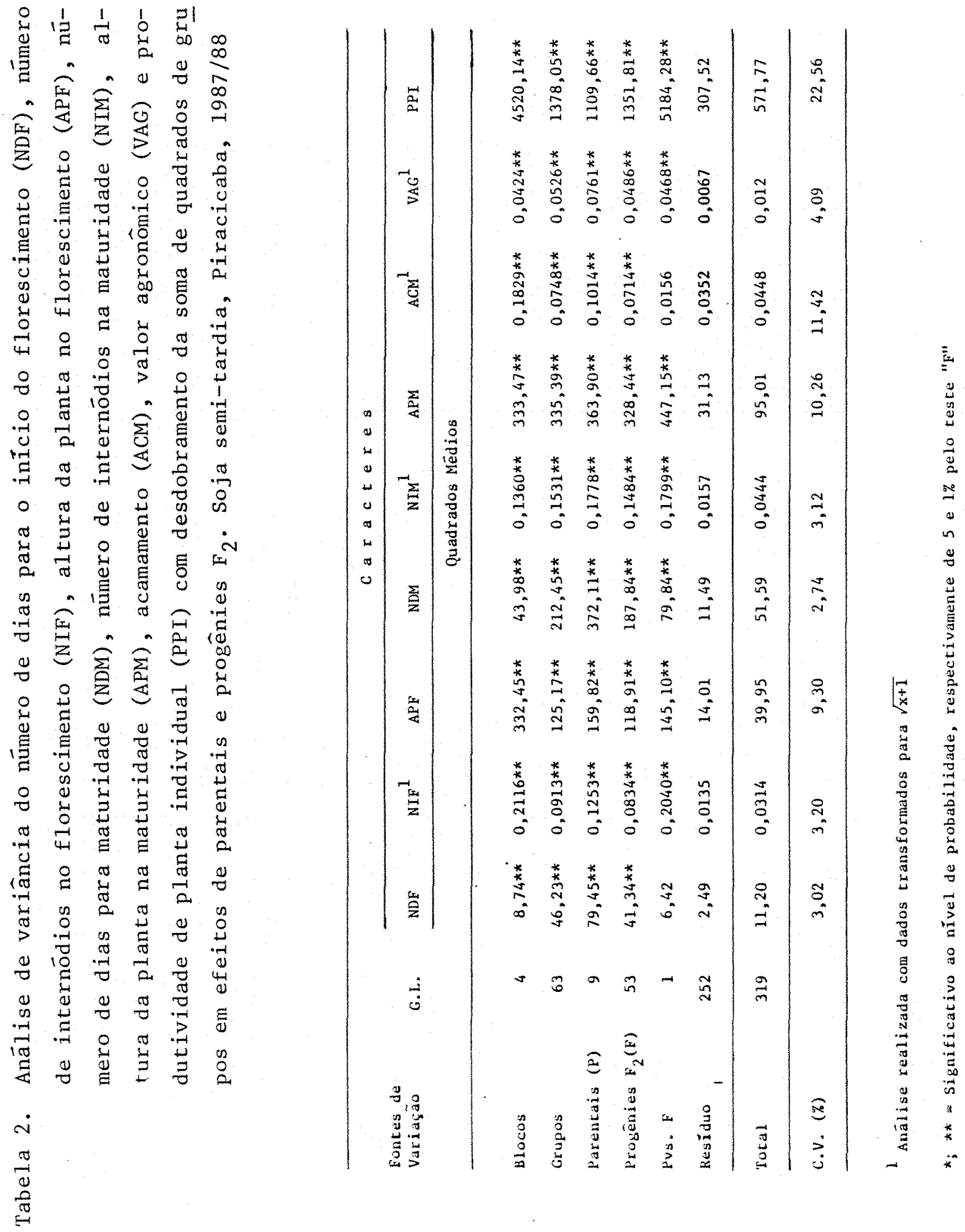


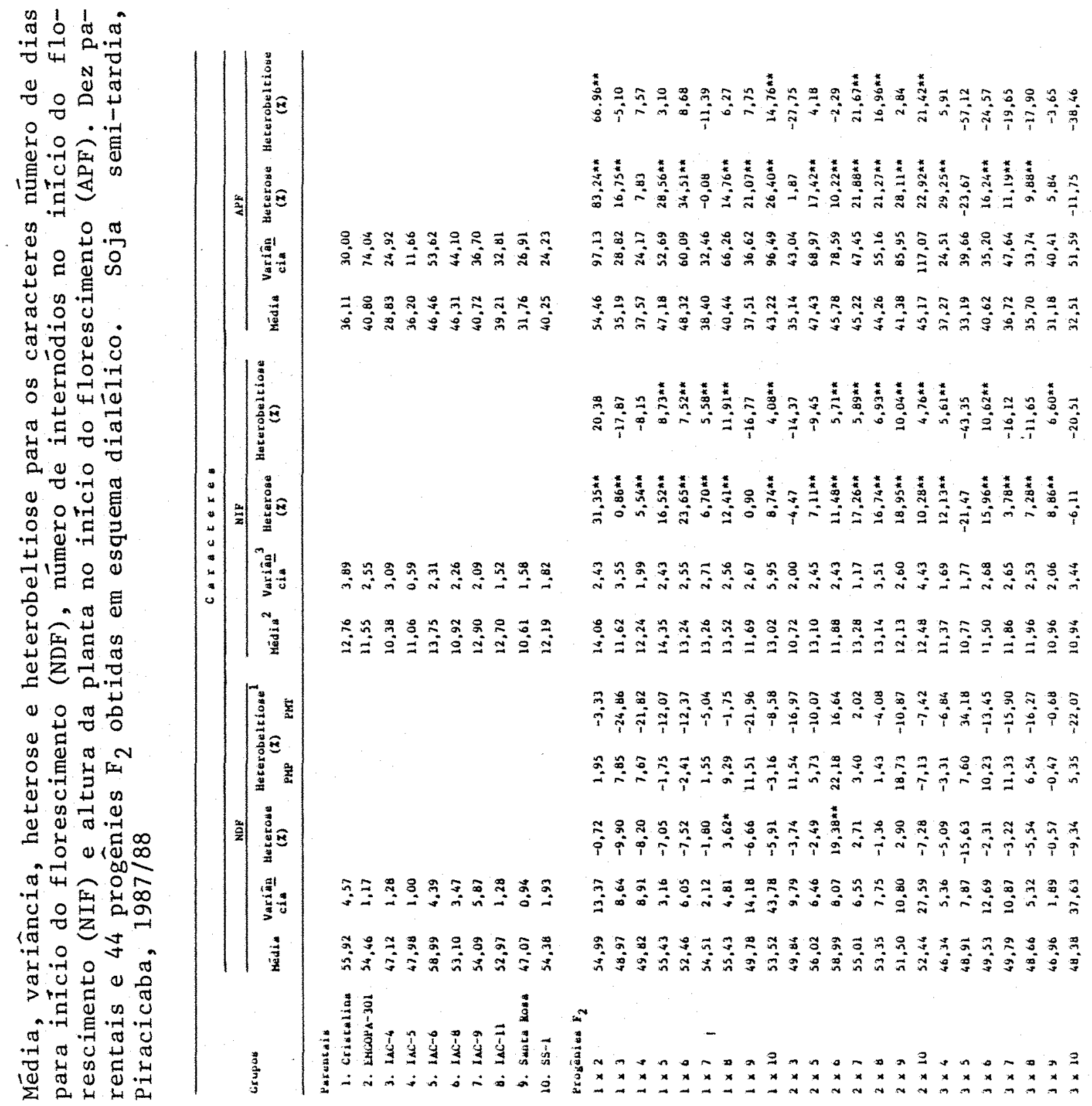

i 


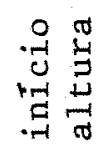

离 0

क.

些晃

(2) 00

녕

원

.

声记足要

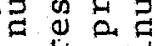

os 0 넢

泋

गै 0 U

u 0

7.

गु न्न

का

०.

क $\circ$ क

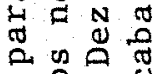

0. ...

ब न्न

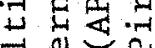

व

동ํㅛ

苟语

出

\& 0 .

- 过 8 .

ब 1 ध

का 1 क क

윤

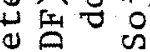

纪。

0 0

$-\pi$ 을

है

10.

.

$>$ क

둥

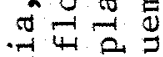

Q 0 \%

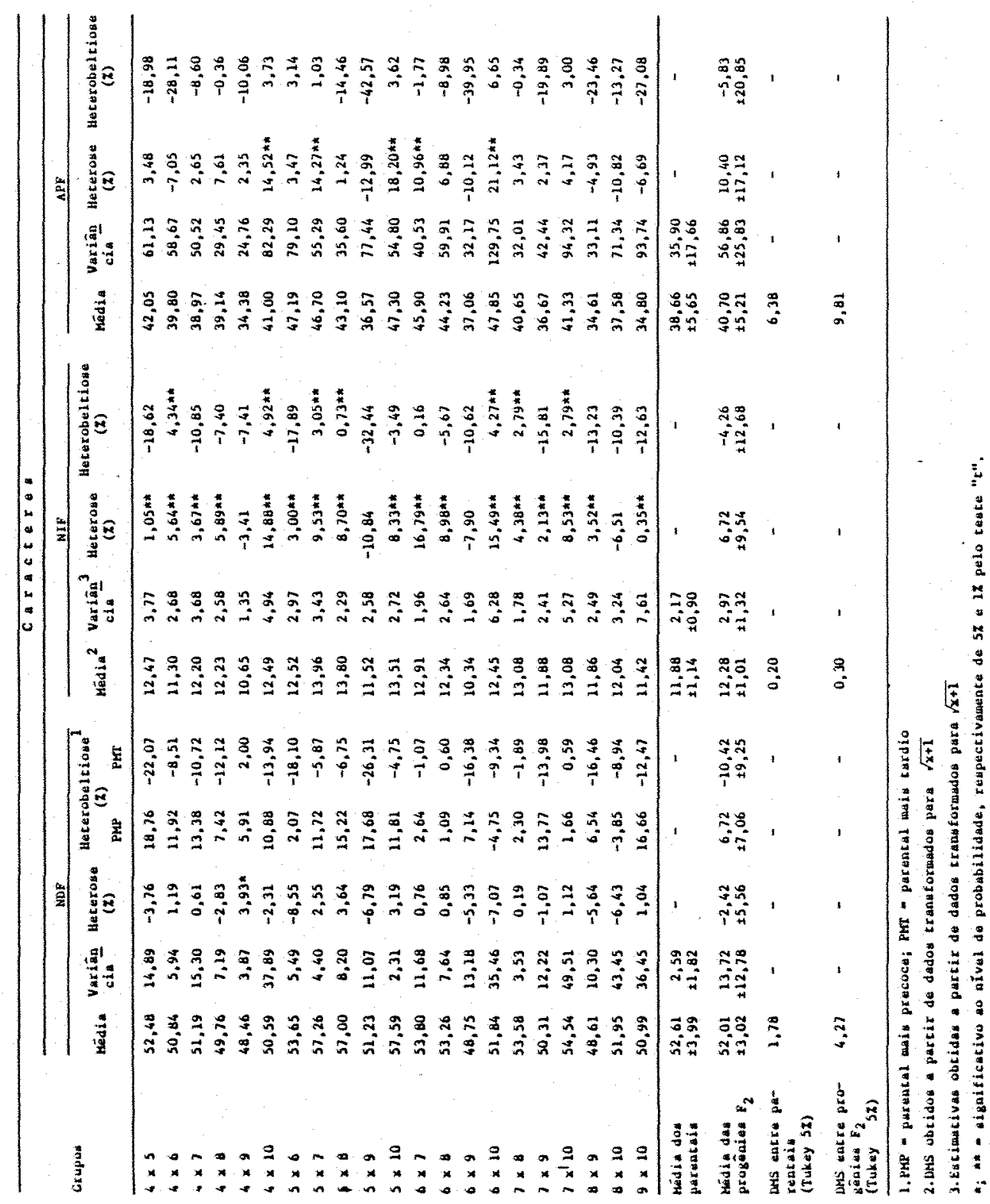

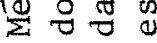

它 


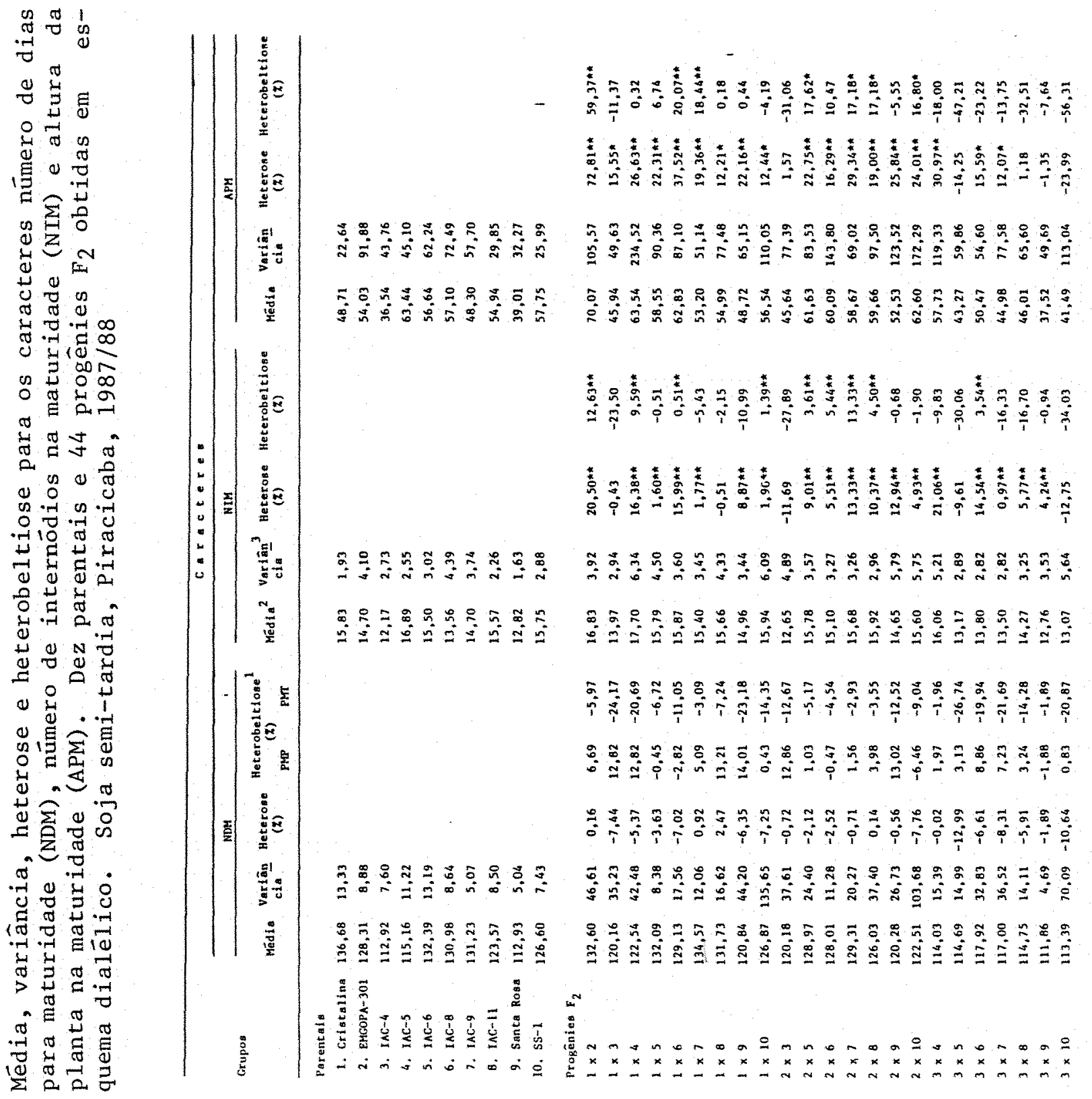




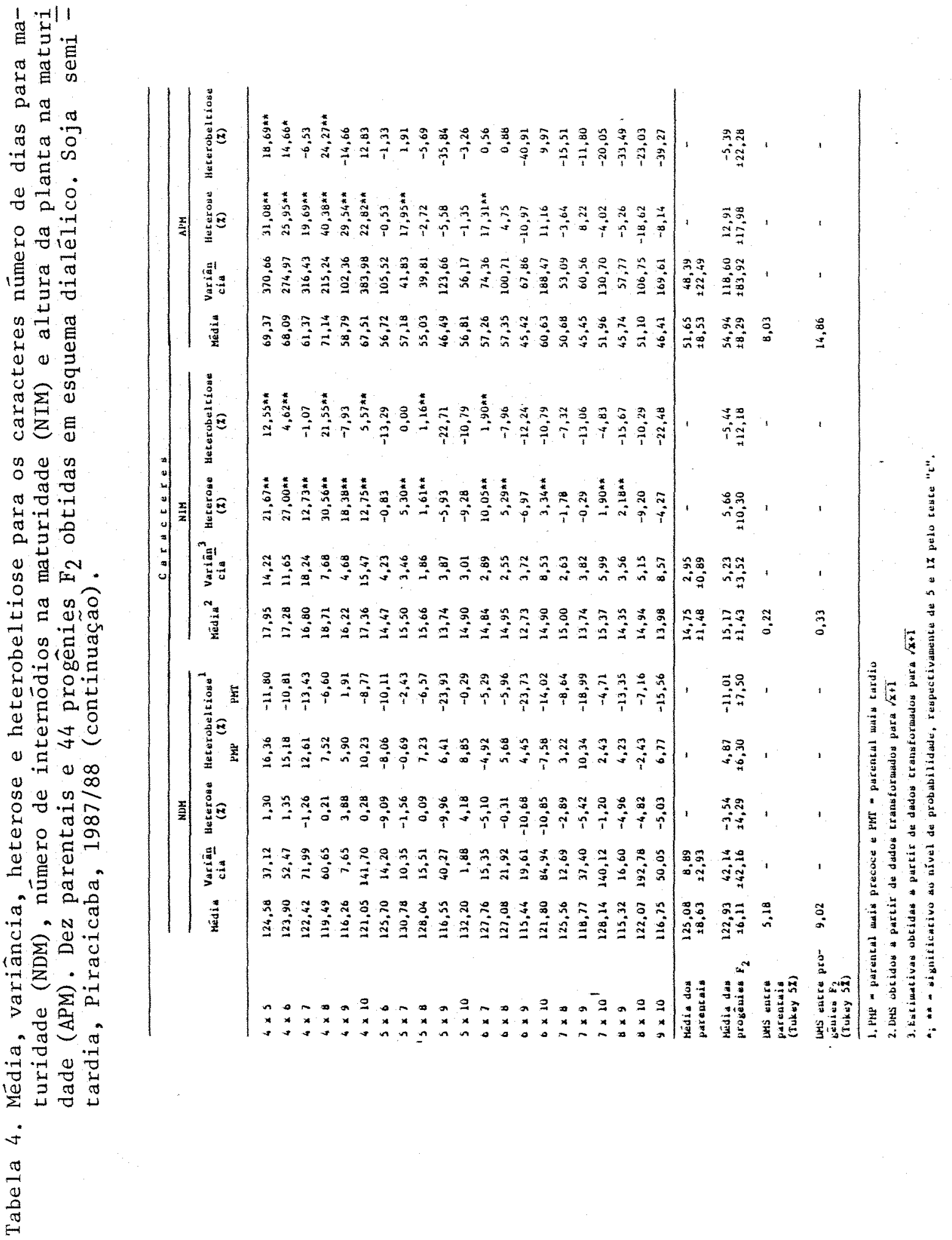




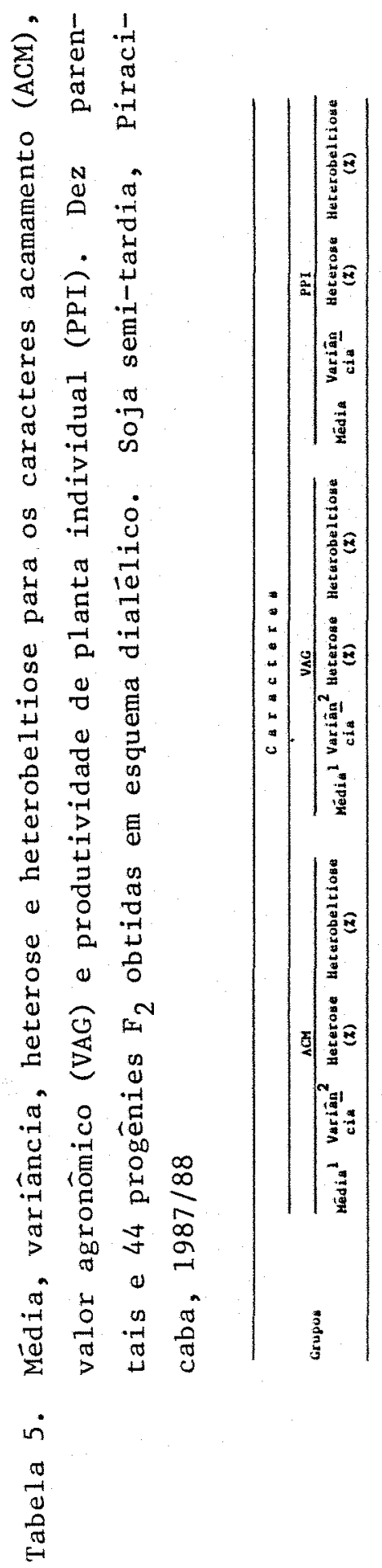

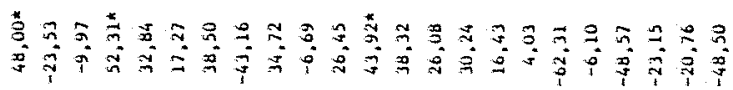

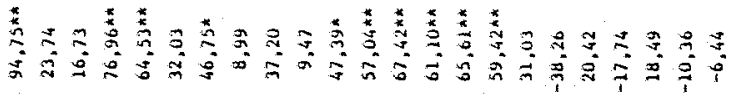

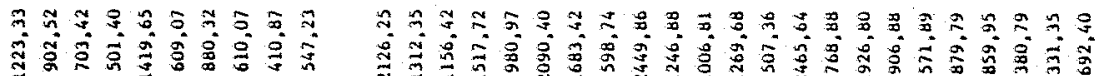
1

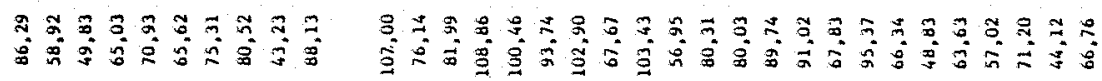

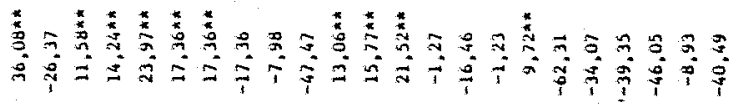

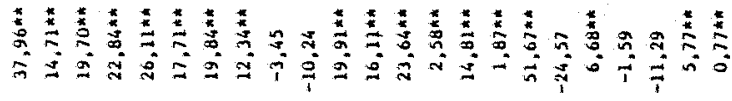

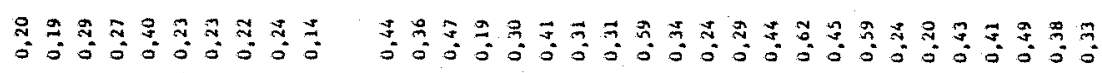

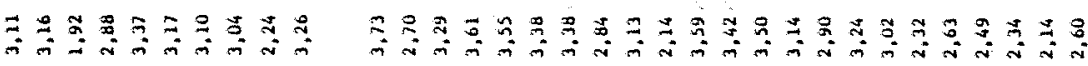

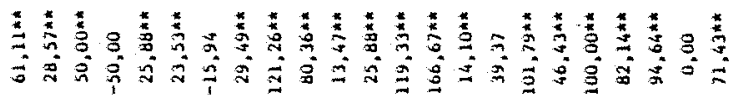

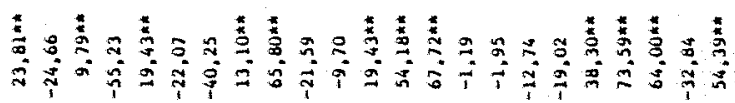

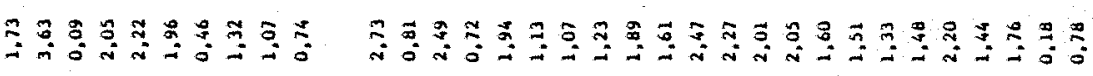

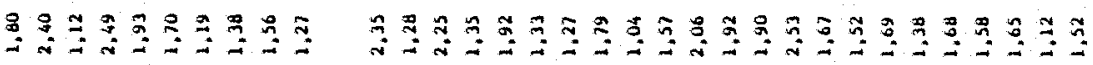

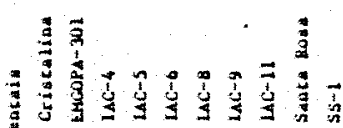

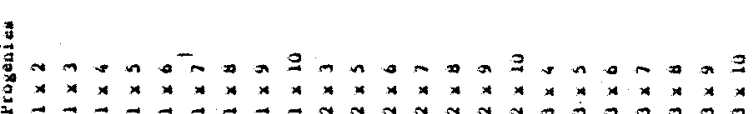




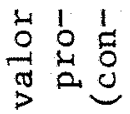

$\sum_{0}^{+\infty} \underset{\infty}{+\infty}$

- के

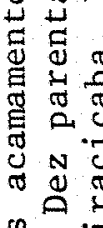

के

4.

馬

$\theta$.

o -

क ํํㅇ.

$\pi$

पू

‥

ㅇำ

.롤

至

뭄

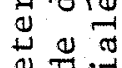

ㄹ

ब. $\cdot \overrightarrow{-}$

a. $\rightarrow$

出 已

ब 0 \&

造

0

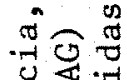

结

ใั

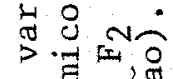

.

焉

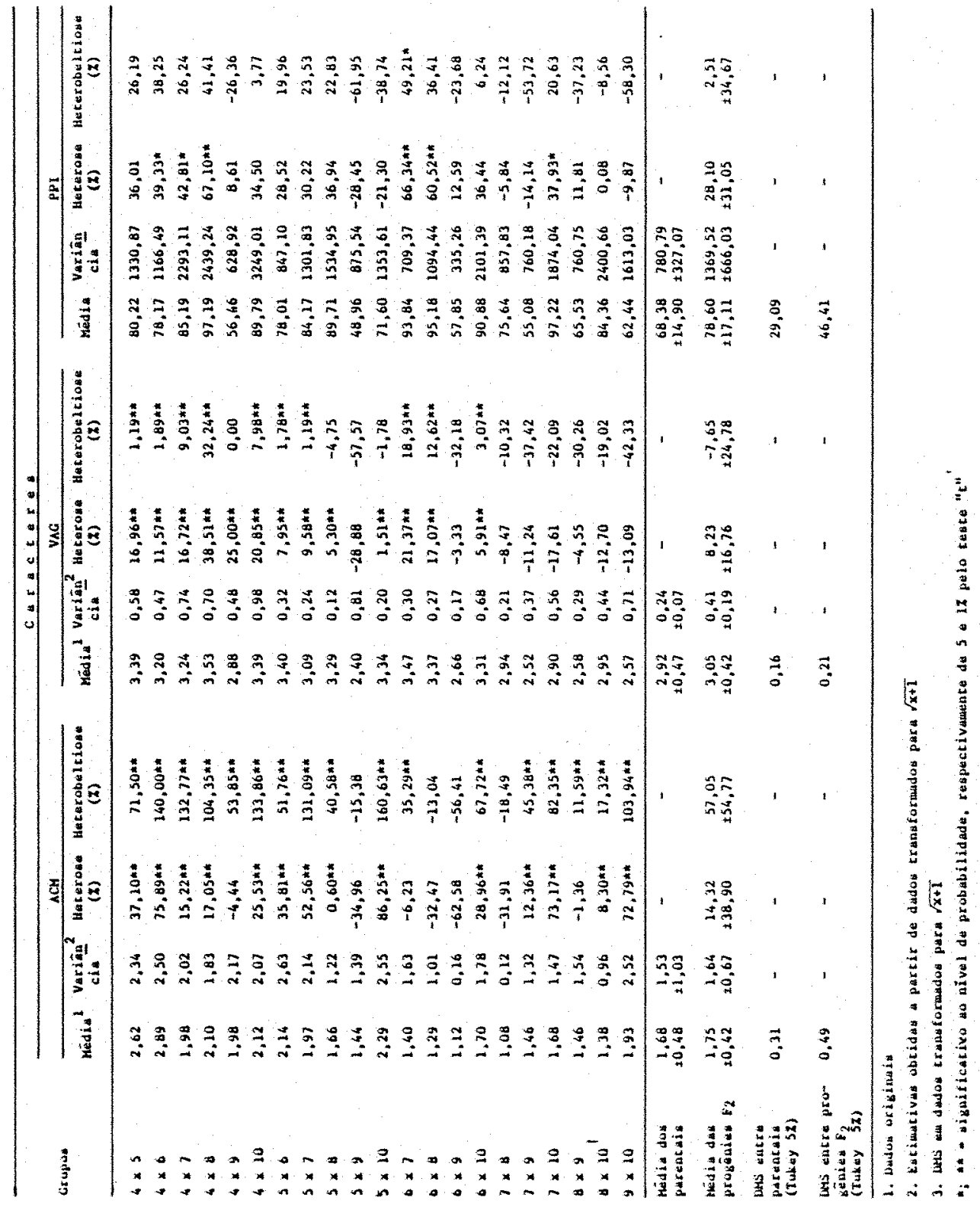

in

$\frac{\pi}{0}$ 

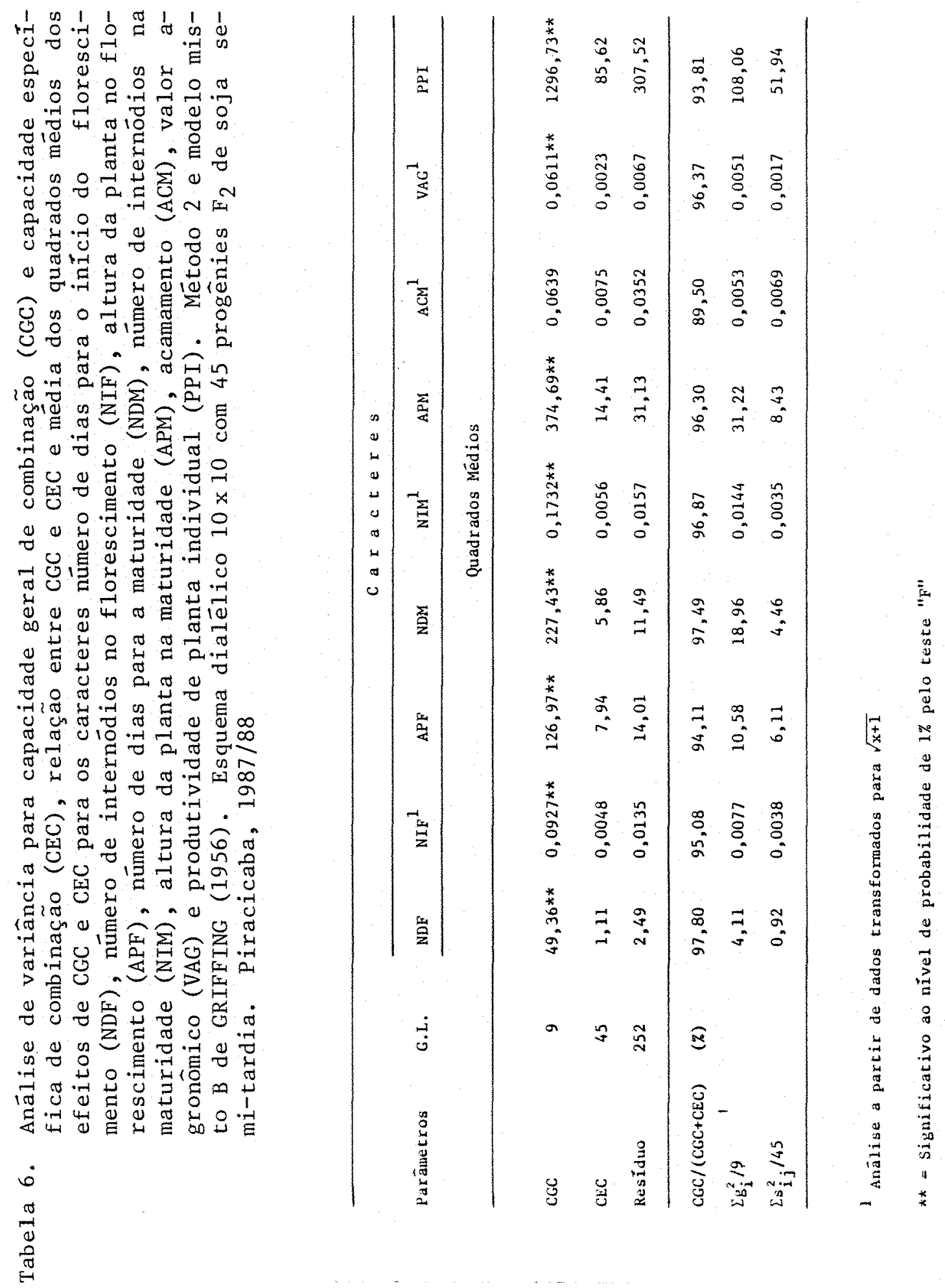

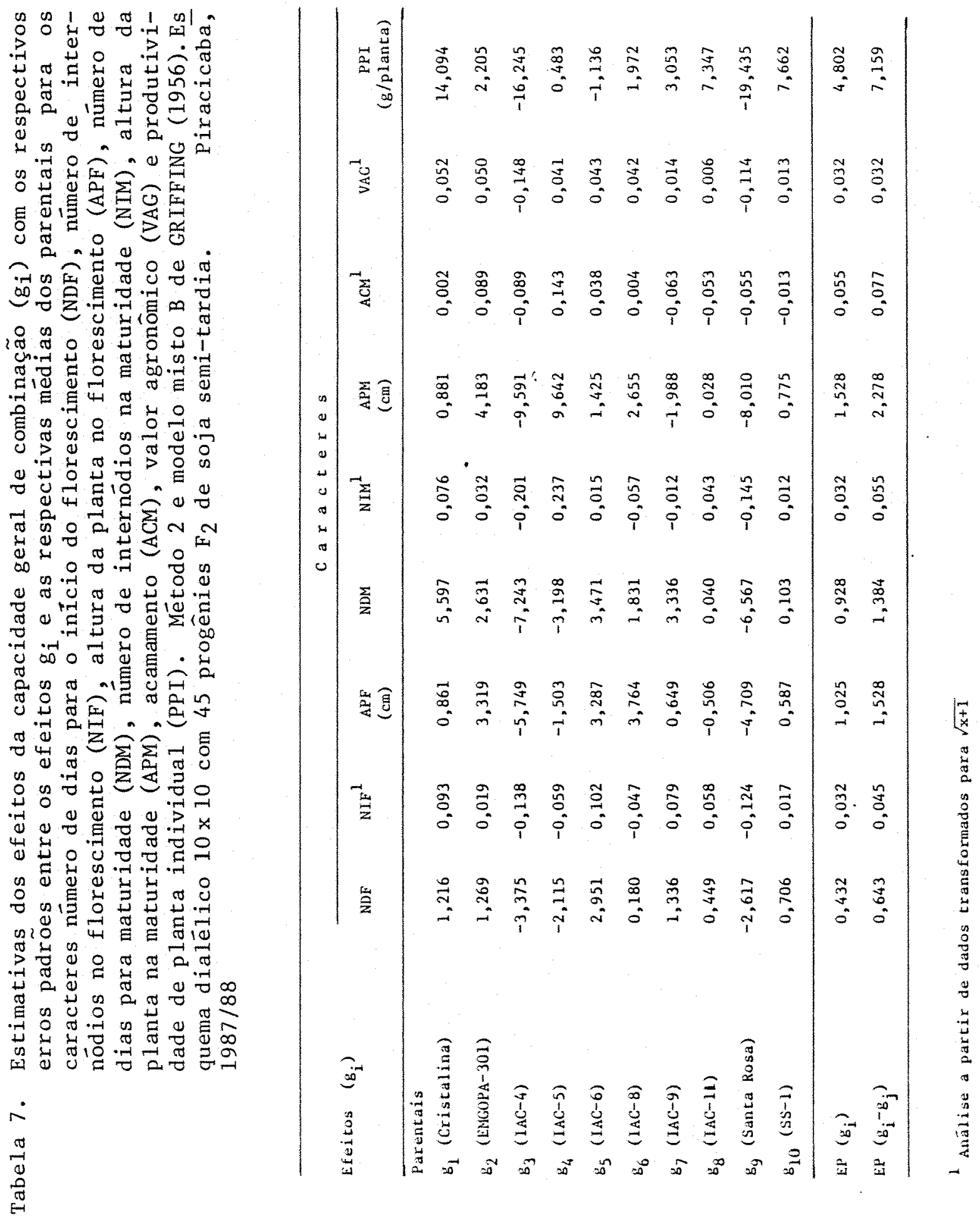

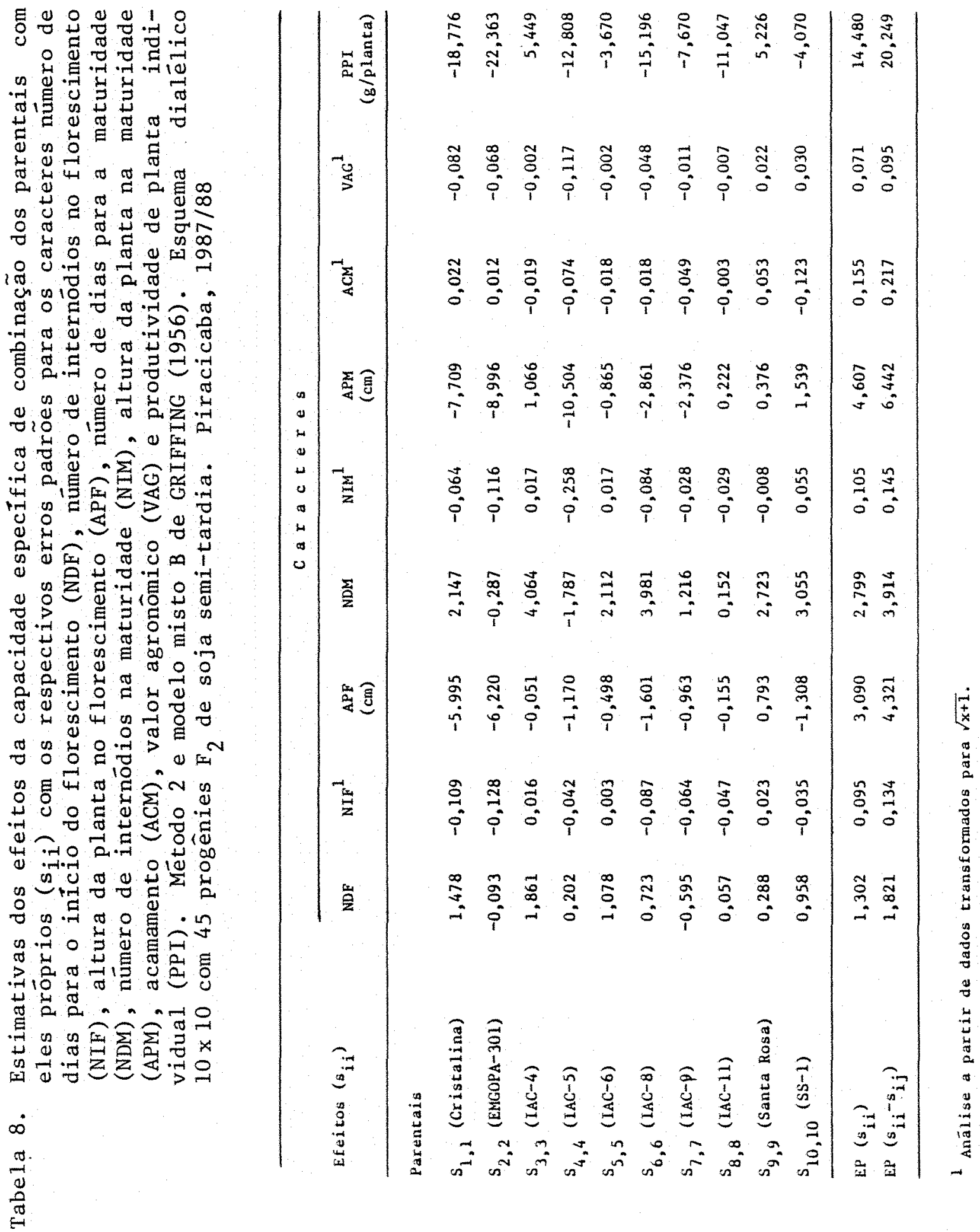
Tabela 9. Estimativas dos efeitos da capacidade especifica de combinação $\left(s_{i j}\right)$ com os respectivos erros padrões para os caracteres número de dias para o florescimento (NDF), número de internódios no florescimento (NIF), altura da planta no florescimento (APF), nu mero de dias para a maturidade (NDM), número de internódios nă maturidade (NIM), altura da planta na maturidade (APM), acamamento (ACM), valor agronômico (VAG) e produtividade de planta individual (PPI). Método 2 e modelo mis to B de GRIFFING (1956). Esquema dialélico $10 \times 10$ com 45 progênies de soja semi-tardia. Piracicaba, 1987/88

\begin{tabular}{|c|c|c|c|c|c|c|c|c|c|}
\hline \multirow[b]{2}{*}{ Efeitos $\left(s_{i j}\right)$} & \multicolumn{9}{|c|}{$C_{A}+C_{C E} \mathrm{C}_{\mathrm{B}}$} \\
\hline & NDF & NIF & $\begin{array}{l}A P F \\
(\mathrm{~cm})\end{array}$ & NDY & NIM & $\begin{array}{l}\mathrm{APM} \\
(\mathrm{cd})\end{array}$ & ACM & va5 & $\begin{array}{c}\text { PPI } \\
(8 / \text { plant })\end{array}$ \\
\hline Progēnier $F_{2}$ & & & & & & & & & \\
\hline$s_{1.2}$ & 0.489 & 0,137 & 9,902 & 1,039 & 0,101 & 10,345 & 0.087 & 0.067 & 13,821 \\
\hline$s_{1.3}$ & $-0,888$ & $-0,035$ & -0.299 & $-1,527$ & $-0,020$ & $-0,005$ & $-0,053$ & 1.014 & 1,412 \\
\hline$s_{1,4}$. & $-1,298$ & $-0,029$ & $-2,167$ & $-3,193$ & $-0,002$ & $-1,641$ & 0,006 & -0.027 & $-9,462$ \\
\hline $5_{1.5}$ & $-0,748$ & 0,089 & 2,656 & $-0,318$ & $-0,008$ & 1,583 & $-0,158$ & 0,046 & 19,028 \\
\hline$s_{1.6}$ & $-0,951$ & 0,095 & 3,313 & $-1,639$ & 0,074 & 4,640 & 0,053 & 0,033 & 7,515 \\
\hline$s_{1.7}$ & $-0,058$ & $-0,029$ & $-3,487$ & 2,299 & $-0,029$ & $-0,347$ & -0.063 & 0,021 & $-0,284$ \\
\hline$s_{1.8}$ & 1,747 & 0,027 & $-0,295$ & 2.750 & $-0,051$ & $-0,579$ & $-0,092$ & 0,031 & 4,587 \\
\hline$s_{1.9}$ & $-0,829$ & $-0,039$ & 0,980 & -1.534 & 0,050 & 1,194 & 0,072 & 0,017 & $-3,860$ \\
\hline$s_{1.10}$ & $-0,420$ & 0.002 & 1,387 & $-2,170$ & 0.014 & 0,228 & 0,103 & $-0,037$ & 4,797 \\
\hline$s_{2.3}$ & $-0,063$ & $-0,089$ & $-2,807$ & 1.453 & $-0,150$ & $-3,610$ & -0.053 & $-0,060$ & $-5,885$ \\
\hline$s_{2.4}$ & 0.138 & 0.031 & 1,371 & 1,001 & 0,076 & 4,039 & 0,003 & 0,036 & 6,434 \\
\hline$s_{2.5}$ & $-0,216$ & 0,000 & 0.447 & $-0,474$ & 0,035 & 1,362 & -0.033 & 0.043 & 2,363 \\
\hline$s_{2.6}$ & 0,527 & $-0,016$ & $-1,684$ & 0,208 & 0,023 & $-2,604$ & $-0,03 B$ & 0,005 & $-1,019$ \\
\hline$s_{2.7}$ & 0,394 & 0,047 & 0.871 & 0,006 & 0,050 & $1, B 18$ & 0,022 & 0,051 & 7,607 \\
\hline$s_{2.8}$ & $-0,378$ & 0,050 & 1,064 & 0,019 & 0,024 & $0,792$. & 0.187 & $-0,026$ & 4,598 \\
\hline$s_{2.9}$ & 0,840 & 0,095 & 2,391 & 0,882 & 0,055 & 1,698 & $-0,057$ & 0,032 & 8,182 \\
\hline$s_{2.10}$ & -1.545 & 0,003 & 0,886 & $-3,559$ & 0.017 & 2,954 & $-0,143$ & $-0,010$ & 8,627 \\
\hline$s_{3.4}$ & $-0,179$ & 0,081 & 4,137 & 1,133 & 0,080 & 3,021 & -0.068 & 0,108 & 5,245 \\
\hline$s_{3.5}$ & $-2,679$ & $-0,167$ & $-4,725$ & $-4,875$ & $-0,064$ & $-3,223$ & $-0,059$ & $-0,079$ & -10.660 \\
\hline$s_{3.6}$ & 0.715 & 0,087 & 2.227 & $-0,004$ & 0,092 & 2.752 & 0.069 & 0,006 & 1,023 \\
\hline$s_{3.7}$ & $-0,282$ & 0,011 & 1,444 & $-2,437$ & 0,007 & 1,901 & 0.105 & $=0,005$ & $-6,660$ \\
\hline$s_{3.8}$ & $-0,424$ & 0.047 & 1,570 & $-1,385$ & 0,053 & 0,912 & 0,115 & $-0,037$ & 3,223 \\
\hline$s_{3.9}$ & 0,941 & 0,088 & 1,262 & 2.329 & 0,041 & 0,467 & -0.055 & 0,029 & 2,931 \\
\hline$s_{3.10}$ & $-0,965$ & -0.056 & $-2,709$ & $-2,814$ & $-0,073$ & $-4,348$ & 0.036 & 0,026 & $-1,527$ \\
\hline 5.5 & $-0,371$ & -0.006 & $-0,113$ & 0,963 & 0.067 & 3,642 & 0,066 & 0,005 & 3,994 \\
\hline$S_{4.6}$ & 0,762 & -0.020 & $-2,840$ & 1.928 & 0.082 & 1,138 & 0,170 & $-0,038$ & $-1,163$ \\
\hline$s_{4.7}$ & $-0,043$ & $-0,021$ & $-0,560$ & $-1,054$ & $-0,020$ & $-0,937$ & $-0,009$ & 0,000 & 4,779 \\
\hline$s_{4.8}$ & $-0,586$ & 0,005 & 0,769 & $-0,692$ & 0,146 & 6.811 & 0,017 & 0,077 & 12,485 \\
\hline$s_{4.9}$ & 1,183 & $-0,037$ & 0,214 & 2,685 & 0,044 & 2,499 & $-0,017$ & 0,038 & $-1,467$ \\
\hline 54.10 & $-0,010$ & 0,081 & 1,530 & 0,802 & 0.023 & 2.436 & $-0,019$ & 0,035 & 4,771 \\
\hline$s_{5.6}$ & $-1,491$ & $-0,011$ & -0.245 & $-2,939$ & $-0,039$ & $-2,018$ & 0,076 & 0,008 & 0,299 \\
\hline$s_{5.7}$ & 0,956 & 0.052 & 2,381 & 0,635 & 0,045 & 3,089 & 0.095 & 0,033 & 5,374 \\
\hline$s_{5.8}$ & 2,583 & 0,054 . & $-0,062$ & 1,190 & 0,009 & $-1,081$ & $-0,008$ & 0,016 & 6.624 \\
\hline$s_{5.9}$ & $-1,116$ & $-0,073$ & $-2,386$ & $-3,692$ & -0.046 & $-1,580$ & $-0,077$ & $-0,090$ & $-7,340$ \\
\hline$s_{5.10}$ & 1,925 & 0.056 & 3,042 & 5,287 & $-0,054$ & $-0,044$ & 0.134 & 0,021 & $-12,340$ \\
\hline$s_{6.7}$ & 0,266 & 0,064 & 1,101 & $-0,751$ & 0,034 . & 1,936 & -0.046 & 0.052 & 11,940 \\
\hline $5_{6.8}$ & 0,617 & 0,008 & 0,585 & 1,873 & -0.007 & 0,010 & $-0,092$ & 0,037 & 8,990 \\
\hline$s_{6.9}$ & $-0,830$ & $-0,095$ & $-2,374$ & $-3,161$ & $-0,107$ & $-3,879$ & $-0,150$ & -0.020 & $-1,563$ \\
\hline$s_{6.10}$ & $-1,061$ & 0,063 & 3.119 & $-3,476$ & 0,017 & 2,547 & $-0,005$ & 0,025 & 4,370 \\
\hline$s_{3.8}$ & $-0,216$ & $-0,019$ & 0,122 & $-1,151$ & $-0,046$ & $-2,015$ & $-0,097$ & $-0,042$ & -11.632 \\
\hline$s_{7.9}$ & $-0,418$ & 0,000 & $=0,345$ & $-1,339$ & $-0,018$ & 0,790 & 0,032 & $-0,031$ & $-5,416$ \\
\hline 57.10 & 0.490 & 0,022 & $-0,292$ & 1,361 & 0,032 & $-1,483$ & 0,059 & $-0,058$ & 9.632 \\
\hline$s_{8.9}$ & $-1,237$ & 0,019 & $-0,557$ & $-1,491$ & 0,006 & $-0,931$ & 0.021 & $-0,004$ & 0,746 \\
\hline${ }^{5} 8.10$ & $-1,221$ & $-0,097$ & -2.887 & $-1,416$ & $-0,077$ & $-4,362$ & $-0,045$ & $-0,038$ & $-7,526$ \\
\hline$s_{9.10}$ & 0.890 & $-0,003$ & $-1,461$ & $-0,126$ & $-0,010$ & $-1,008$ & 0,125 & $-0,015$ & -2.665 \\
\hline$E\left(s_{i j}\right)$ & 1,452 & 0,105 & 3,447 & 3.123 & 0.114 & 5.139 & 0,173 & 0,077 & 16.153 \\
\hline EP $\left(s_{i j}-s_{i n}\right)$ & 2,135 & 0,158 & 5,067 & 4,590 & 0,170 & 7.554 & 0,253 & 0,110 & 23,744 \\
\hline $\operatorname{EP}\left(s_{i j}-s_{k I}\right)$ & 2,036 & 0,152 & 4.832 & 4,377 & 0,261 & 7.203 & 0.243 & 0,105 & 22,639 \\
\hline
\end{tabular}

I Análise partir de dados transformados pata $\sqrt{\mathrm{X}+1}$ 


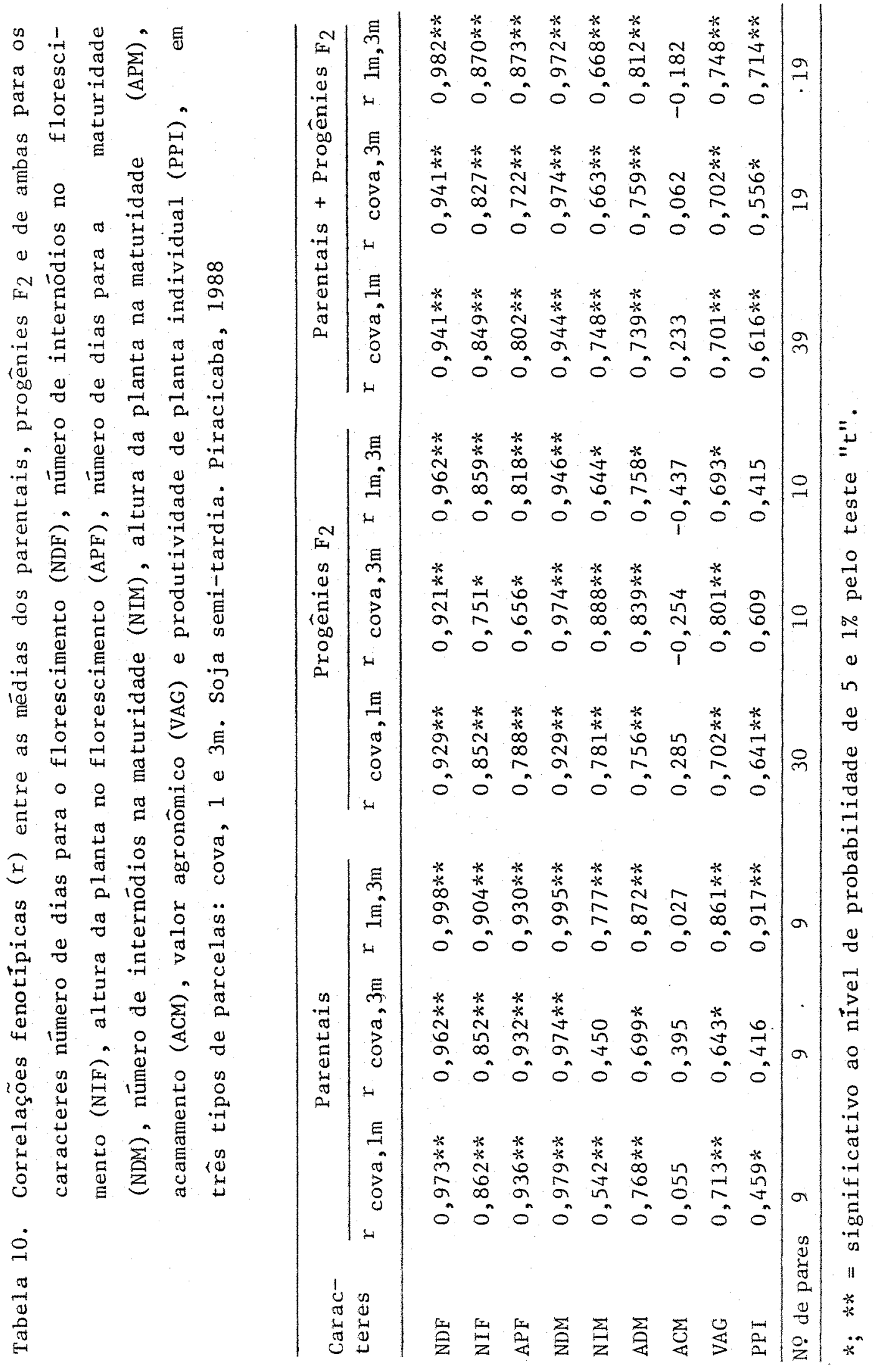


A P E N D I C E 


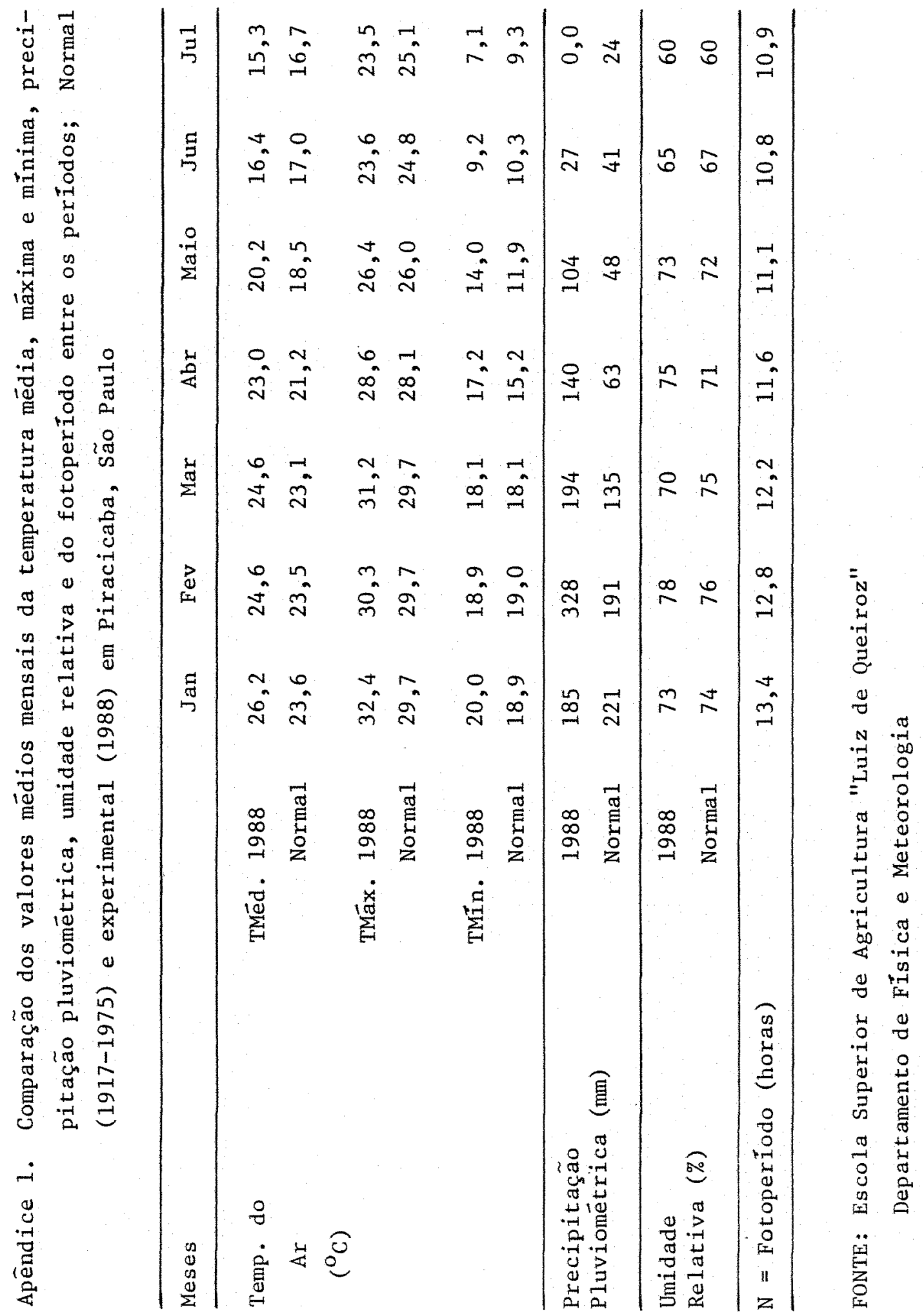

